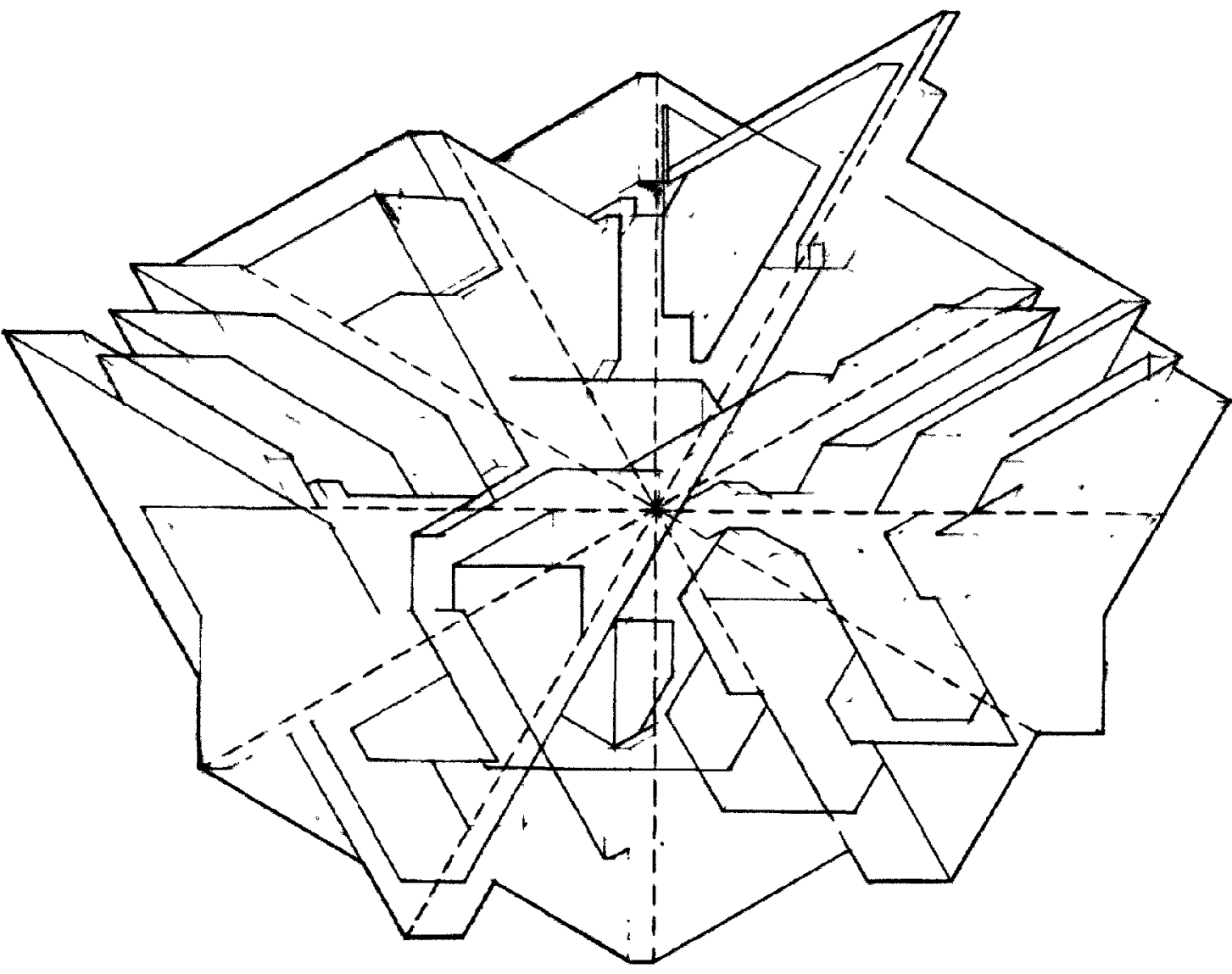

S PECULAT I ON S:

TRACES OF THE AXONOMETRIC MACHINE 



\section{SPECULATIONS: \\ Traces of the AXONOMETRIC Machine}

INCLUDING :

A 'CABINET OF WONDER' WHICH STRUCTURES, ORGANIZES AND INVOLVES AN EXPLORATION OF INTERIOR \& ANTERIOR TRACES

JARED HAGENS

A thesis SUBMitted to the FaCulty of GRAduAte and Postdoctoral affairs IN PARTIAL FULFILLMENT OF THE REQUIREMENTS FOR THE DEGRE OF

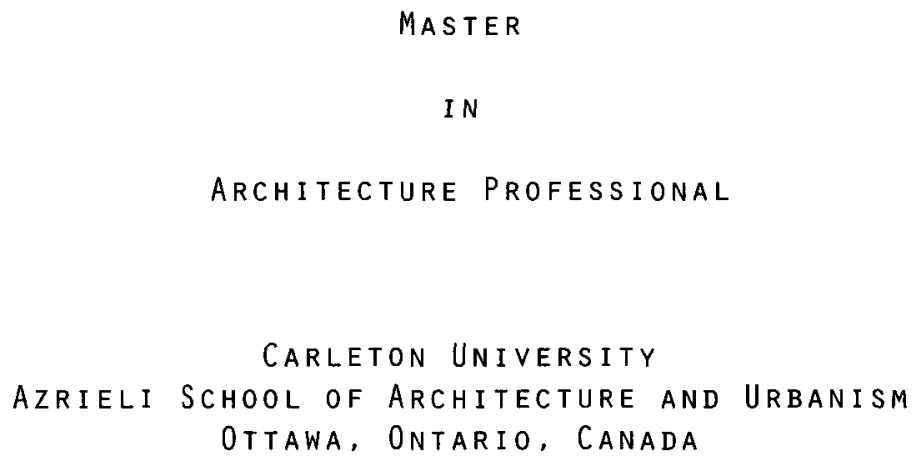


Library and Archives
Canada

Published Heritage Branch

395 Wellington Street Ottawa ON K1A 0N4 Canada
Bibliothèque et

Archives Canada

Direction du

Patrimoine de l'édition

395 , rue Wellington

Ottawa ON K1A ON4

Canada
Your file Votre référence

ISBN: 978-0-494-81725-4

Our file Notre référence

ISBN: 978-0-494-81725-4

\section{NOTICE:}

The author has granted a nonexclusive license allowing Library and Archives Canada to reproduce, publish, archive, preserve, conserve, communicate to the public by telecommunication or on the Internet, loan, distribute and sell theses worldwide, for commercial or noncommercial purposes, in microform, paper, electronic and/or any other formats.

The author retains copyright ownership and moral rights in this thesis. Neither the thesis nor substantial extracts from it may be printed or otherwise reproduced without the author's permission.
AVIS:

L'auteur a accordé une licence non exclusive permettant à la Bibliothèque et Archives Canada de reproduire, publier, archiver, sauvegarder, conserver, transmettre au public par télécommunication ou par l'Internet, prêter, distribuer et vendre des thèses partout dans le monde, à des fins commerciales ou autres, sur support microforme, papier, électronique et/ou autres formats.

L'auteur conserve la propriété du droit d'auteur et des droits moraux qui protège cette thèse. $\mathrm{Ni}$ la thèse ni des extraits substantiels de celle-ci ne doivent être imprimés ou autrement reproduits sans son autorisation.
In compliance with the Canadian Privacy Act some supporting forms may have been removed from this thesis.

While these forms may be included in the document page count, their removal does not represent any loss of content from the thesis.
Conformément à la loi canadienne sur la protection de la vie privée, quelques formulaires secondaires ont été enlevés de cette thèse.

Bien que ces formulaires aient inclus dans la pagination, il n'y aura aucun contenu manquant. 


\section{A B S TRACT}

The following thesis implements a process of imaginative spatial development; First, through the use of illusionary representation techniques to manipulate conventional axonometric drafting practices in order to create impossible spatial arrangements. And second, through constructing architectural models to translate the resultant spatial illusions into allusions of architectural possibilities.

The inquiry challenges current axonometric drawing practices in architectural representation by developing an alternative methodology of axonometric drawing that acts as a generator of

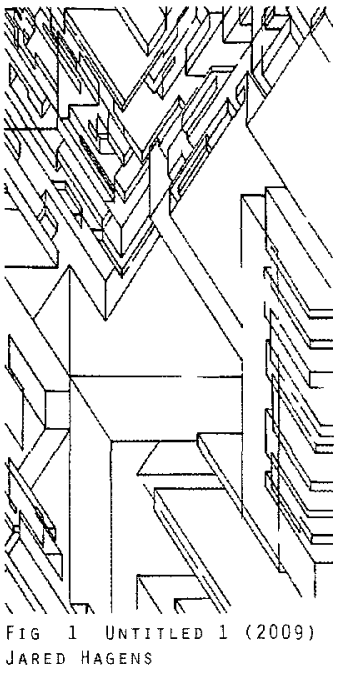
space, form, ideas and design through the provocation and manipulation of one's imagination.

The thesis will demonstrate how spatial development techniques can be used to generate and inspire an imaginative full-scale prototype of what might otherwise be a generic object, through the application of typical criteria used to define and develop the object. The prototype is a representation of the architecture that exists within the traces of its own design; demonstrating the applicability and potential of the investigating process of imaginative spatial development.

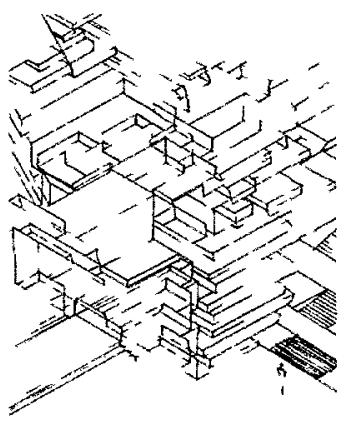




\section{TABLE OF CONTENTS}

$\begin{array}{cc}\text { PG } & \text { I } \\ \text { PG } & \text { II } \\ \text { PG } & \text { III } \\ \text { PG } & \text { IV } \\ \text { PG } & \text { V } \\ \text { PG } & \text { VI VII } \\ \text { PG } & 01-04 \\ \text { PG } & 05 \quad 06 \\ \text { PG } & 07 \\ \text { PG } & 08 \% 09\end{array}$

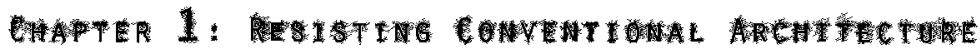

1.1 ARCHITECTURE DRAWINGS

$P G \quad 10-12$

1.2 SPECULATIONS: RESTRAINING BIM

$P G \quad 13-18$

1.3 COSMOPOIESIS

6)

2.1 PROUNS

2. 2 STRUCTURAL CONSTELLATIONS

$P G \quad 23-26$

2.3 MICROMEGAS

$P G \quad 27 \quad 28$

PG $\quad 29 \quad 30$

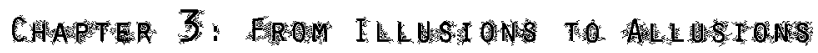

3.1 DRAWING GAZE

3.2 ILLUSIONS + PERCEPTION

3.3 MOdEL TRANSLATIONS

FROM ILLUSIONS TO ALLUSIONS DIAGRAM

PG $\quad 3132$

$P G \quad 33 \quad 34$

$P G \quad 35-36$

$P G \quad 37 \quad 38$

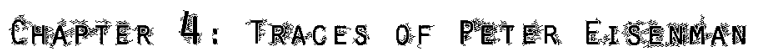

$P G \quad 39 \times 45$

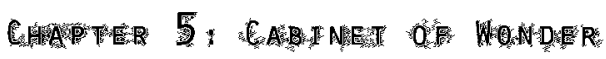

P.G. $\quad \begin{array}{rr}46 & 47 \\ 50 & 51\end{array}$

DESIGN PROCESS DIAGRAMS

$P G$

$48 \quad 49,52$

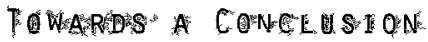

$P G \quad 53.61$

APPENDICES

PG $\quad 62 \quad 96$

B I B L I OGRAPHY

PG $\quad 97 \quad 98$ 


\section{GLOSSARY}

A PRIOR I ; adj [Oxford English Dictionary 2011 http //oxforddictionaries com] Relating to or denoting reasonıng or knowledge whıch proceeds from theoretical deduction rather than from observation or experience

ABSTRACT[ION]; adj/n [lbid Oxford] Existing in thought or as an idea but not having a physical or concrete existence - The process of considerıng somethıng independently of its associations or attributes [OED]

ABSTRACT MACH I NE ; [cf Garcia Mark The Dlagrams of Architecture 2010] "they are conceptually and ontologically distınct from materıal realıty yet they are fully functionıng machınes nonetheless, that is, they are agencies of assemblage, organization and deployment"

ALLUSION; n [lbid Oxford] An expression designed to call somethıng to mınd without mentionıng it explicitly, an indırect or passıng reference

ANTER I ORITY OF ARCHITECTURE ; [ff Eisenman Peter Diagram An Original Scene of Writing. 1999] The history/historical traces in/of architecture

AXONOMETRIC; adj [Ibid Oxford] Using or denoting an orthographic projection of an object, such as a buildıng, on a plane inclined to each of the three principal axes of the object, three dimensional but without perspective

COSMOPOIES IS; [cf Frascarı Marco From Drawings to Modeis 2007]

"World-makıng that starts from a world already at hand the makıng is remakıng"

CONSTRUCT IVISM; n [lbid Oxford]

Art a style or movement in which assorted mechanıcal objects are combıned into abstract mobıle structural forms The movement orıgınated in Russia in the 1920 s and has influenced many aspects of modern architecture and desıgn

DECONSTRUCTION; n [lbid ]

A method of critical analysis of philosophical and literary language which emphasizes the internal workings of language and conceptual systems, the relational quality of meanıng, and the assumptions implicit in forms of expressıon

D I A GRAM ; n [lbid ]

A sımplıfied drawing showing the appearance, structure, or workıngs of somethıng, a schematic representation

[DRAWING] GAZE; n [lbid]

A particular perspective consıdered as embodyıng certaın aspects of the relationshıp between observer and observed

EXTERIORITY OF ARCHITECTURE; [lbid of Elsenman] Agents/Influences/traces outsıde of architecture

I LLUS I ON; n [Ibid Oxford] The prınciple or technıque by whıch artistic representations are made to resemble real objects or to give an appearance of space by the use of perspective

INTERIORITY OF ARCHITECTURE ; [Ibid cf Eisenman ] Other possible architectures that are withın

I N T U I T I ON ; n flbid Oxford] The abılity to understand somethıng instinctively, without the need for conscious reasonıng

I MAG INAT I ON; $n$ [lbid] The faculty or action of formıng new ideas, or Images or concepts of external objects not present to the senses

M I CROCOSM: n [lbid ] a community, place, or situation regarded as encapsulating in mınıature the characteristics of somethıng much larger

PERCEPT I ON: $\mathrm{n}$ [lbid ] - the ability to see, hear, or become aware of somethıng through the senses

- the neurophysıologıcal processes, includıng memory, by whıch an organısm becomes aware of/ınterprets external stımulı - Intuitive understandıng and insight

SPECULATE[IVE]; v/ad] [lbid]

- Form a theory or conjecture about a subject without firm evidence

- Engaged in, expressıng, or based on conjecture rather than knowledge

SUPREMAT I SM $n$ [lbid ]

The Russian abstract art movement developed by Kazımır Malevich cırca 1915, characterized by simple geometrical shapes and associated with ideas of spiritual purity 


\section{LIST OF ILLUSTRATIONS}

FIGURE 1:

FIGURE 2 :

FIGURE 3 :

FIGURE 4:

FIGURE 5 :

FIGURE 6 :

FIGURE 7 :

FIGURE 8 :

FIGURE 9 :

FIGURE 10:

FIGURE 11 :

FIGURE 12 :

FIGURE 13:

FIGURE 14:

FIGURE 15:

FIGURE 16:

FIGURE 17 :

FIGURE 18 :

FIGURE 19:

FIGURE 20 :

FIGURE 21 :

FIGURE 22 :

FIGURE 23:

FIGURE 24 :

FIGURE 25:

FIGURE 26:

FIGURE 27 :

FIGURE 28 :

FIGURE 29:

FIGURE 30 :

FIGURE 31:

FIGURE 32:

FIGURE 33 :

FIGURE 34 :

FIGURE 35 :

FIGURE 36 :

FIGURE 37 :

FIGURE 38 :

FIGURE 39:

FIGURE 40:

FIGURE 41:

FIGURE 42:

FIGURE 43:
Untitled $1 /(2009) /$ Jared Hagens $\ldots \ldots \ldots \ldots \ldots \ldots \ldots \ldots \ldots \ldots \ldots \ldots \ldots \ldots$ I II

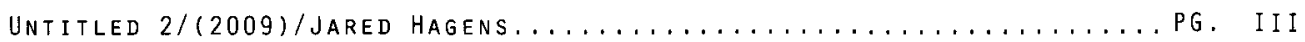

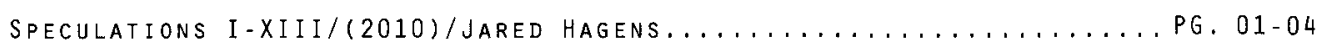

The five books of Architecture/(1611)/Sebastiano Serlio ............ 05

Urban Passage Project/(1974)/Massimo Scolari ................... 05

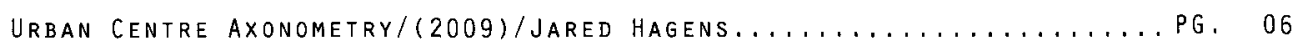

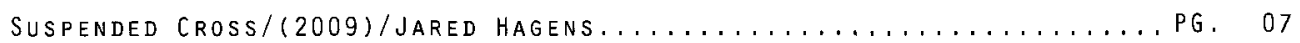

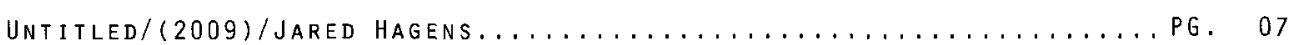

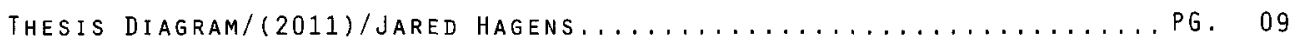

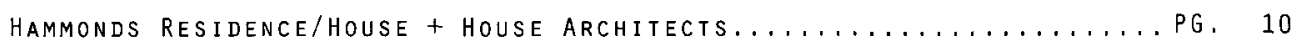

SERIES 800 WINDOW SYSTEMS/CHAMPION WINDOWS + DOORS/BOYD ALUMINUM..... PG. 11

CS 77 -FP El60 doOR detail/Reynaers Alluminum ..................

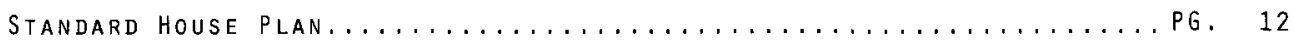

bim collaborated Model/m. A. Mortenson Company.................

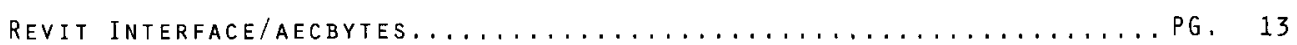

COllaborated 3 -D Structural \& Mechanical layout/aecbytes.............

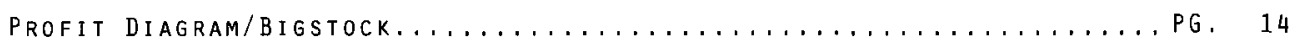

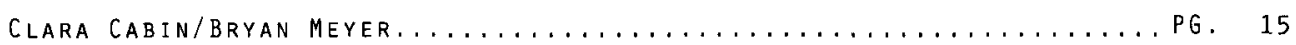

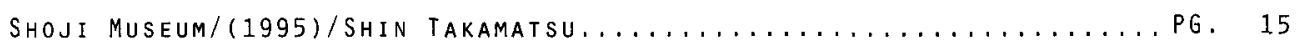

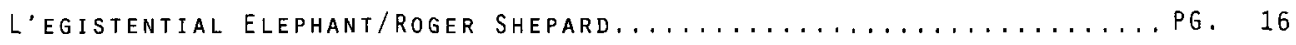

Necker Cube/(1832)/Louis Albert Necker...................... 16

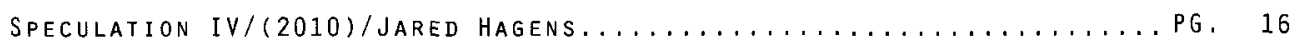

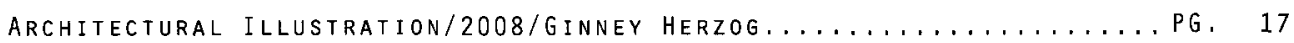

Las Meninas $/(1957) /$ Pablo Picasso $\ldots \ldots \ldots \ldots \ldots \ldots \ldots \ldots \ldots \ldots \ldots \ldots \ldots \ldots$

SPECUlation $V /(2010) /$ JaREd Hagens $\ldots \ldots \ldots \ldots \ldots \ldots \ldots \ldots \ldots \ldots \ldots \ldots, \ldots \ldots$

Garden of Earthly Delights: Central Panel/(1504)/Hieronymus BOSCH.... PG. 18

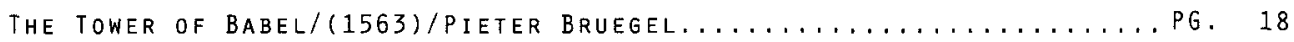

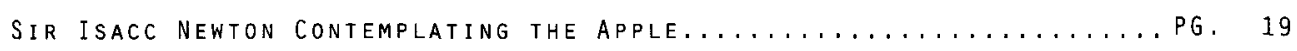

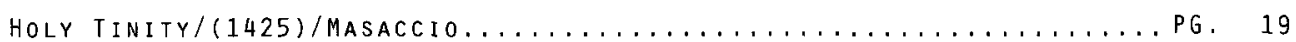

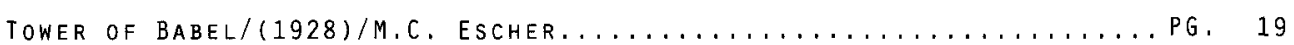

Muller house PLAN/(1928)/Adolf LOOS ....................... 20

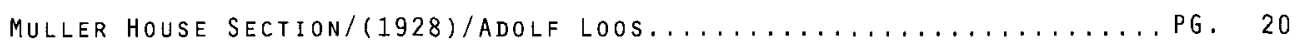

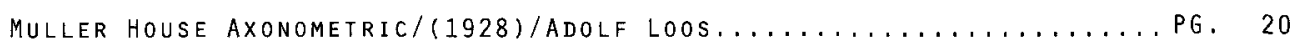

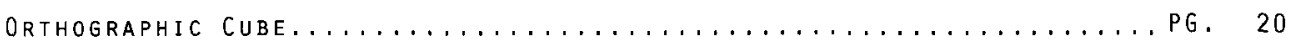

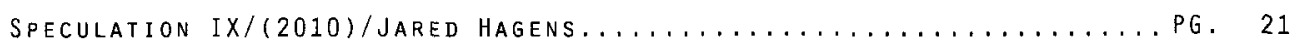

PROUN $1-D /(1919-1924) / E L$ LISSITZKY....................... 21

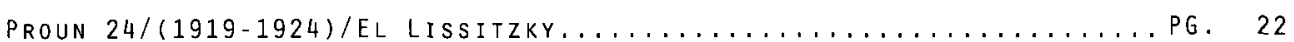

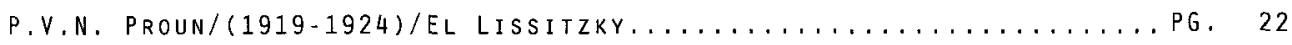

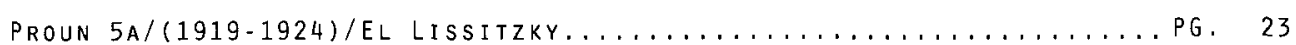

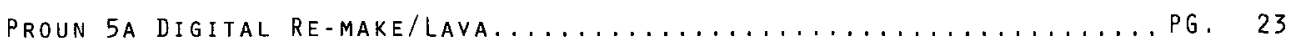

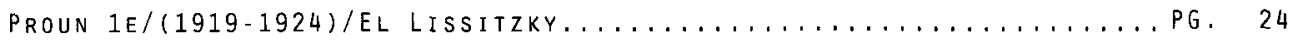

PROUN SPACE/(1923)/EL LISSITZKY........................ 24

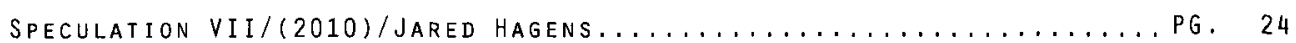

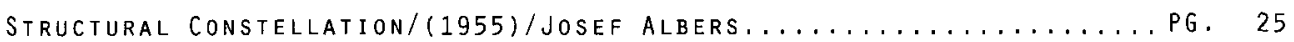

Structural CONStellation/(1955)/JOSEf Albers................. PG. 25 
FIGURE 44: FIGURE 45: FIGURE 46 : FIGURE 47: FIGURE 48: FIGURE 49 : FIGURE 50: FIGURE 51: FIGURE 52 : FIGURE 53: FIGURE 54 : FIGURE 55: FIGURE 56: FIGURE 57 : FIGURE 58 : FIGURE 59: FIGURE 60:

FIGURE 61: FIGURE 62: FIGURE 63: FIGURE 64: FIGURE 65: FIGURE 66: FIGURE 67: FIGURE 68: FIGURE 69: FIGURE 70: FIGURE 71 : FIGURE 72 : FIGURE 73-74:

FIGURE 75: FIGURE 76 : FIGURE 77: FIGURE 78: FIGURE 79: FIGURE 80:

FIGURE 81-89:

FIGURE 90 : FIGURE 91 ; FIGURE 92 ; FIGURE 93:

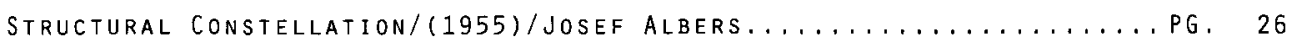

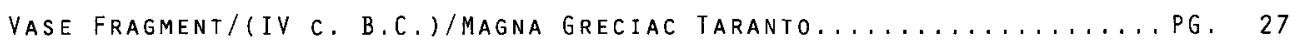

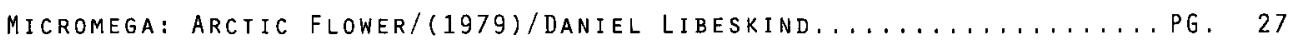

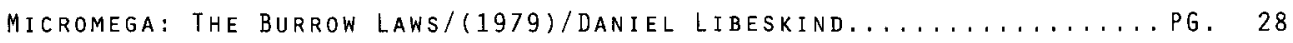

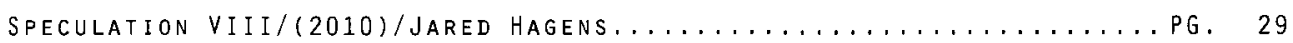
Micromega: Vertical HORIZONS/(1979)/Daniel Libeskind ............ PG. 29

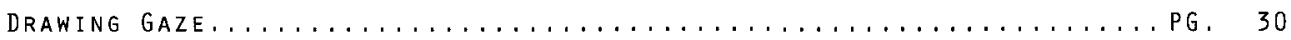

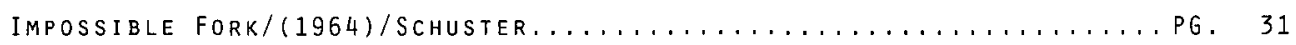

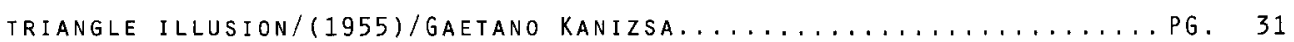

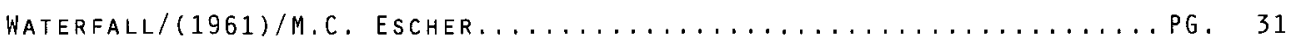

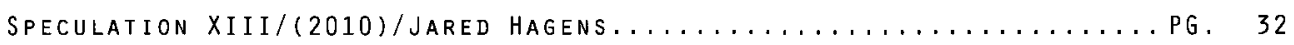
Terra Subterranea/Size COnstancy Illugion/Roger Shepard............ 32 YOUNG GIRL-OLD WOMAN ILLUSION/(1915)/W.E. HILL................ 32

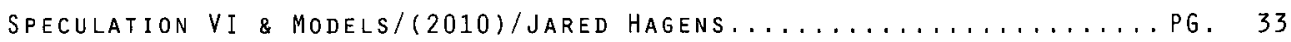
Michelangelo presenting Model to the Pope/Casa buonarroti, firenze... Pg. 34

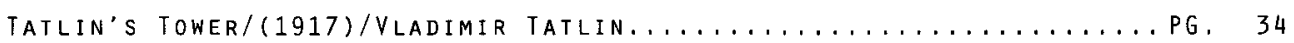

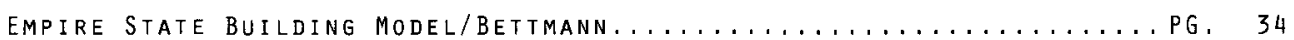
SPECUlations I-XiII \& MOdels/(2010)/Jared Hagens ................ $35-36$ Unite d'habitation diagram/(1945)/Le CORbusier................. 37

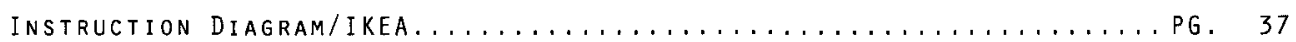
Diagram For ExtraterRestrials/(1972)/CARl Sagan................ 37 Diagram of an Ideal CIty/(1464)/Antonio di Pietro averlino........... 38

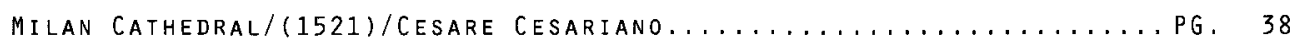
Deleuzian diagrammatic Processes/(1995)/Patrik Schumacher........... 38 house i I Process diagram/(1969)/Peter EisenMan................. House Vi Process diagram/(1975)/Peter Eisenman ................

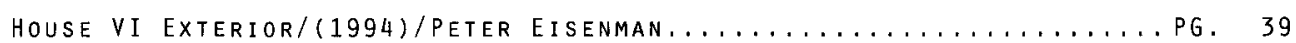

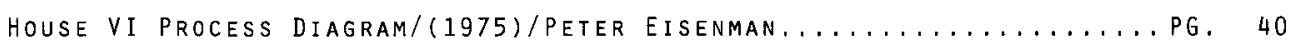

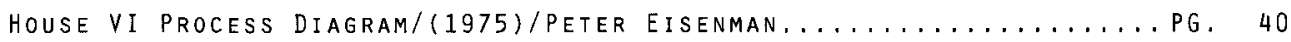

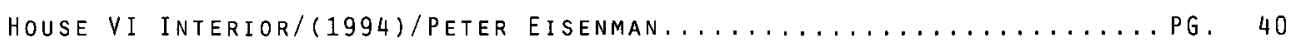
analytical diagram of the church of the redeemer (Diagram of anteri-

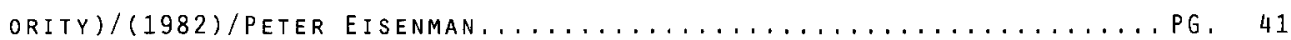

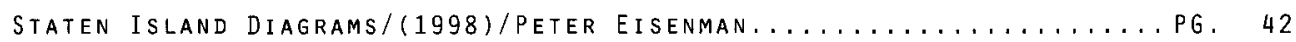

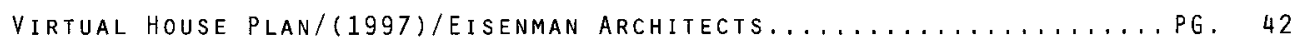
A CABinet of CuRiosity/(1690)/DOMEnico Remps .................

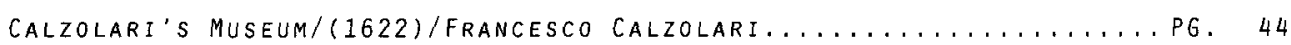

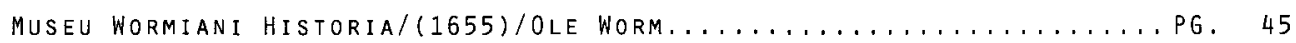
Cabinet of WOnder: Digital Rendering/(2011)/Jared hagens ........... 45 DESign Process diagram/ $(2011) /$ Jared hagens ................... 47 Cabinet of Wonder Photographs/(2011)/Jared hagens ............... 48.49 Cabinet of Wonder Photographs diagram/(2011)/Jared hagens ........... 50

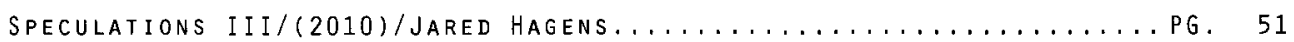
SPECUlations $x /(2010) / J a R E d$ Hagens $\ldots \ldots \ldots \ldots \ldots \ldots \ldots \ldots \ldots \ldots \ldots \ldots \ldots \ldots$ SPECUlations II $(2010) /$ Jared Hagens $\ldots \ldots \ldots \ldots \ldots \ldots \ldots \ldots \ldots \ldots \ldots \ldots \ldots$ SPECUlations $X I I /(2010) / J a R E D$ Hagens..................... 52

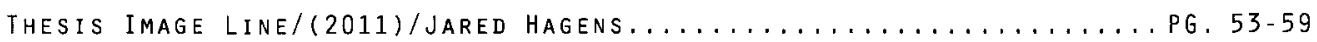


SPECULATIONS

FIG: I - XIII

DAtE: JAN-FEB / 2010

DRAWN BY: JARED HAGENS

MEdiUm: GRAPHIte/VELUM
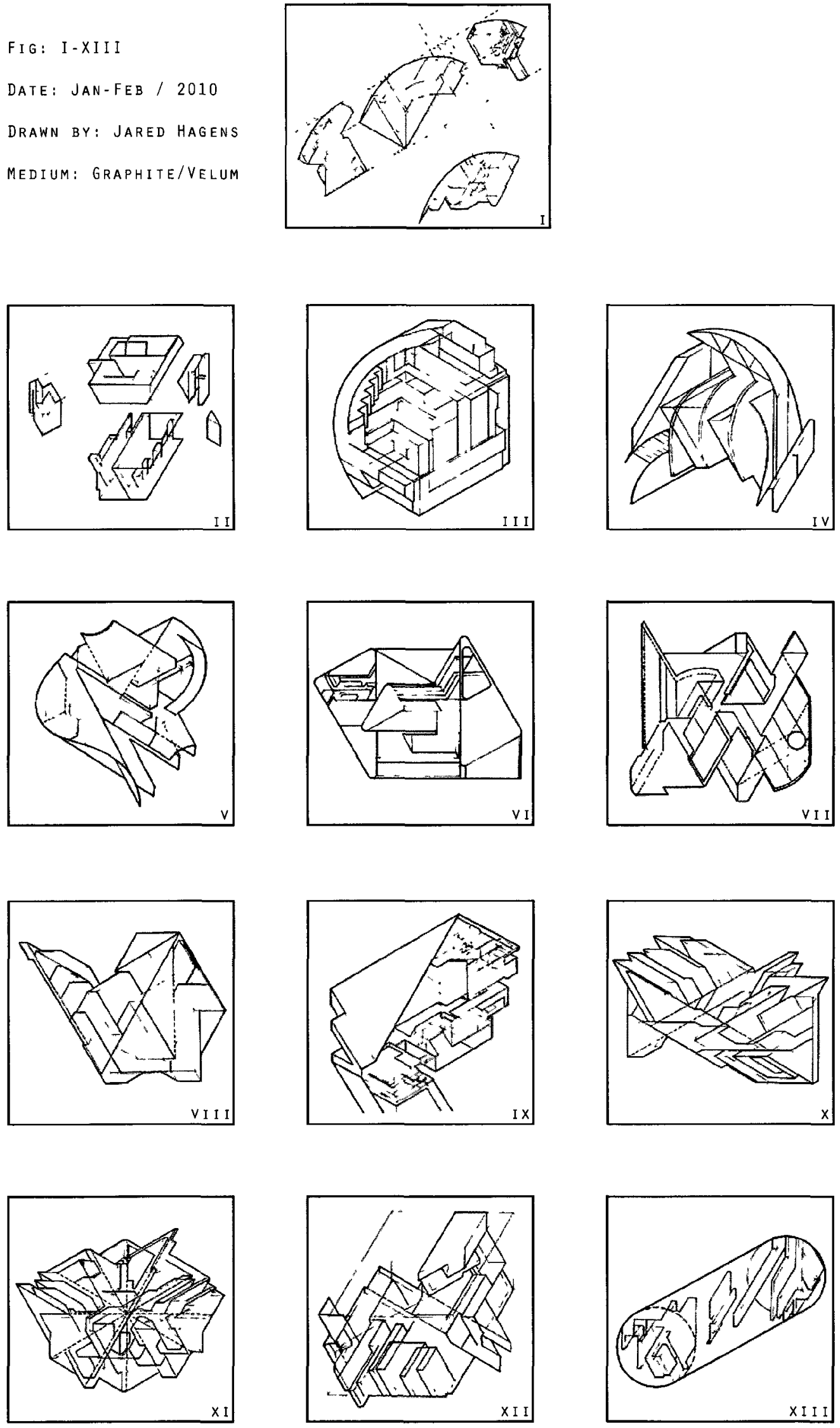


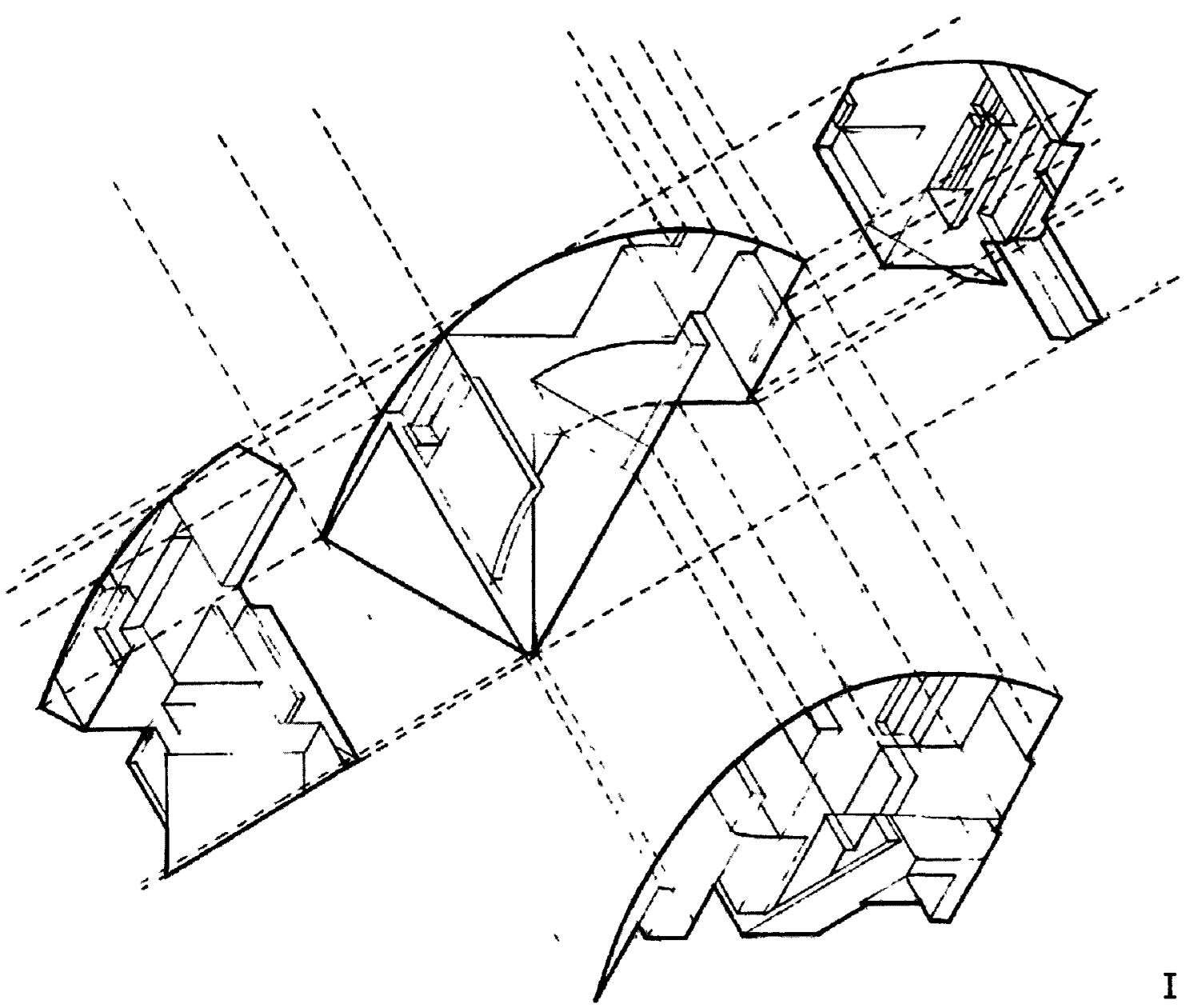

The following image SERIES are adaptations of analogue axonometric drafting techniques

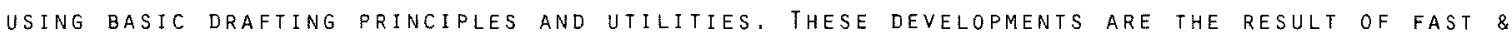
FLUID DRAFTING OPERATIONS WHERE NO ATTENTION TO PARTICULAR SCALES AND MEASUREMENT IS TAKEN into acCOUNT. This Methodology allows for geOMetries to deVElop and articulate much like a

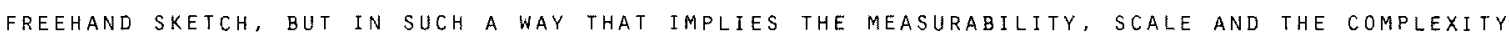
of a fully articulated design. Thereby provoking the viewer to want to accept their spatial

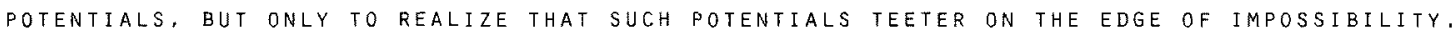
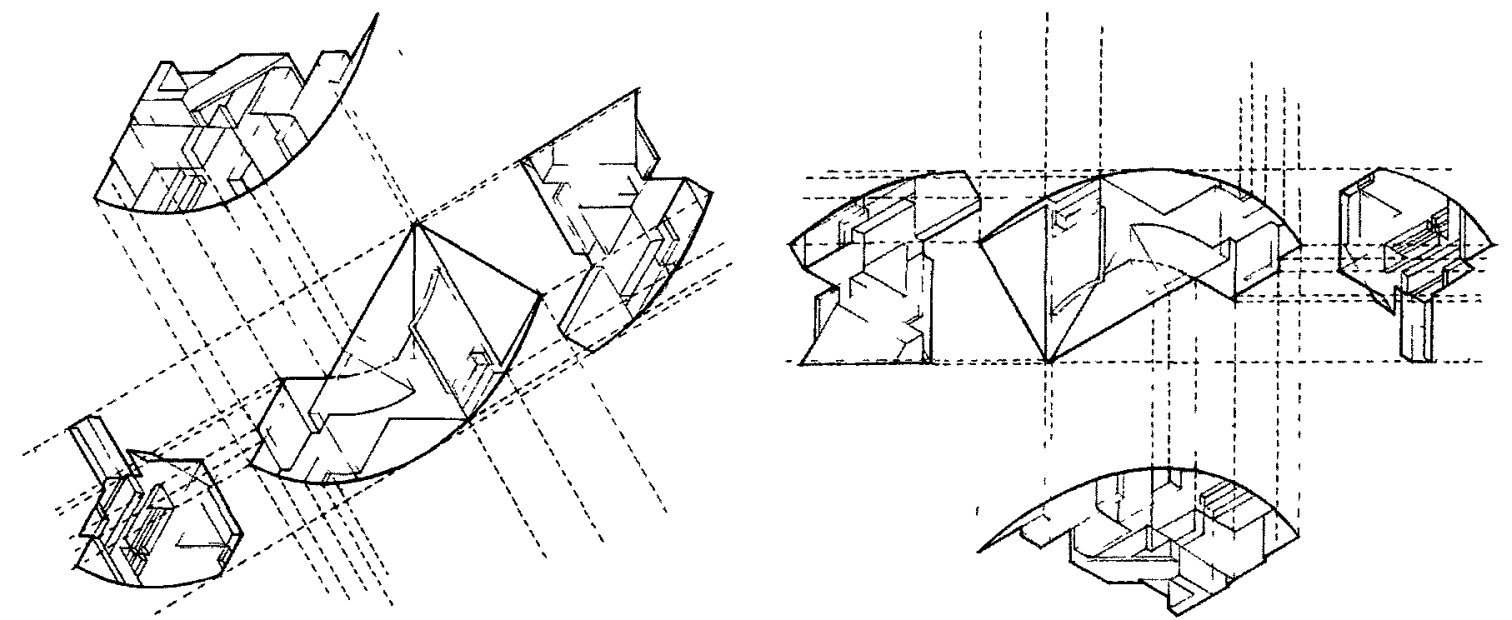

Simple ROtations in the orientation of EACH SPECULATion provoke imaginative interPRETATIONS OF POTENTIAL SPATIAL ARRANGEMENTS WHICH DRASTICALLY RE-ORDER INTO NEW POTENTIAL ASSEMBLIES, 


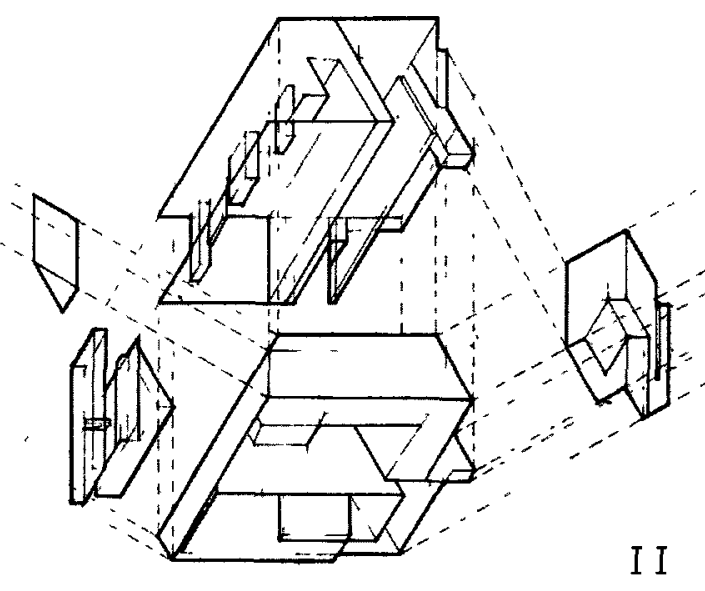

EXPLODED WORM/BIRD'S EYE AXONOMETRIC PORTRAYING POTENTIAL CONNECTIONS.

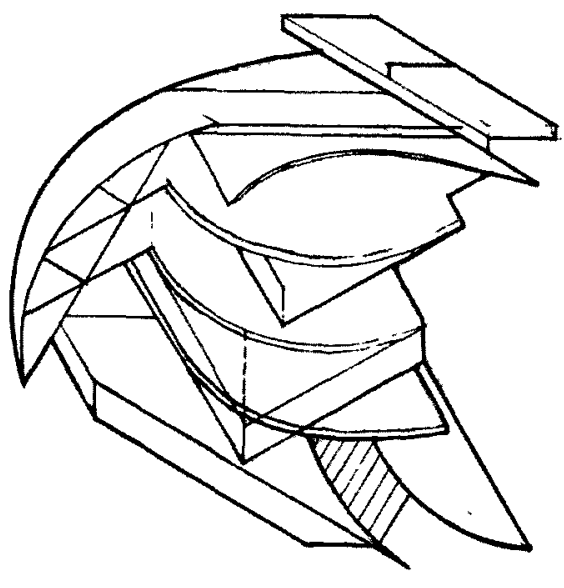

IV

PROTRACTOR - SIX TRACES AND/OR

FLOOR PLATES.

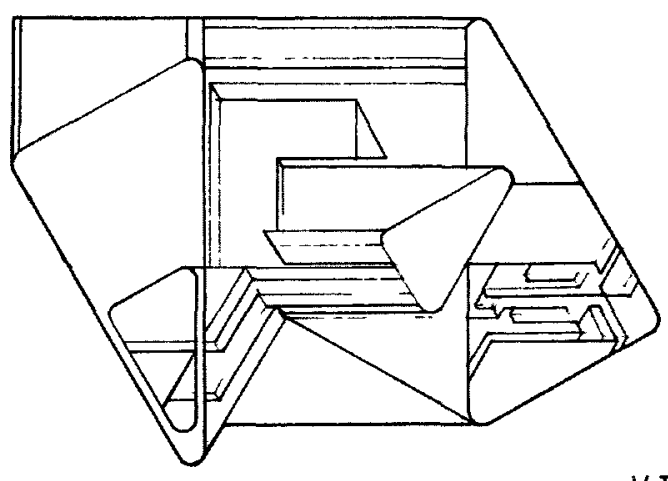

V I

Positive \& negative triangle traces. IMPLIED MOVEMENT - EXTENDING.

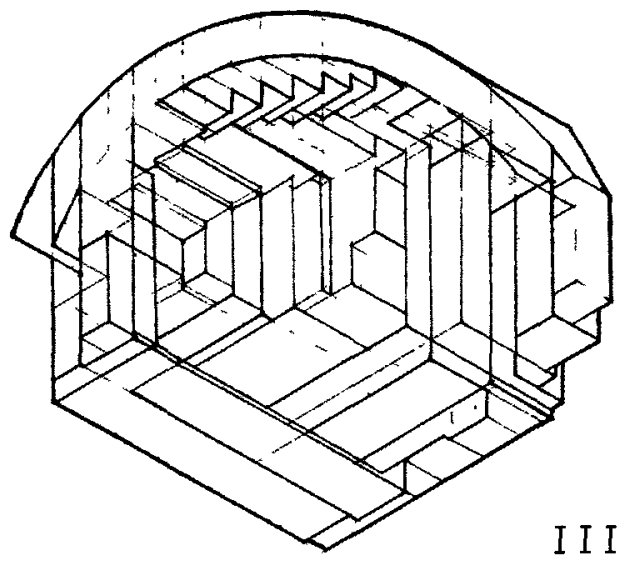

FLUCTUATING POTENTIAL INTERIOR VIEWS WITH EXTERIOR FACADES.

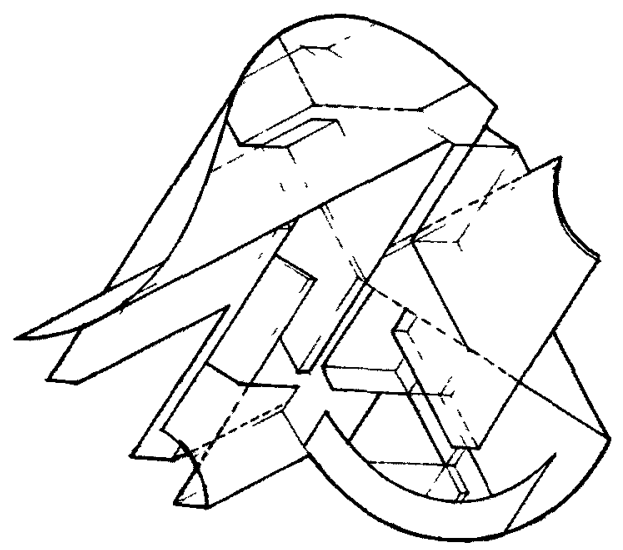

V

CCENTUATED CURVES, IMPLIED TRANS -

PARENT OVERLAPPING GEOMETRIES.

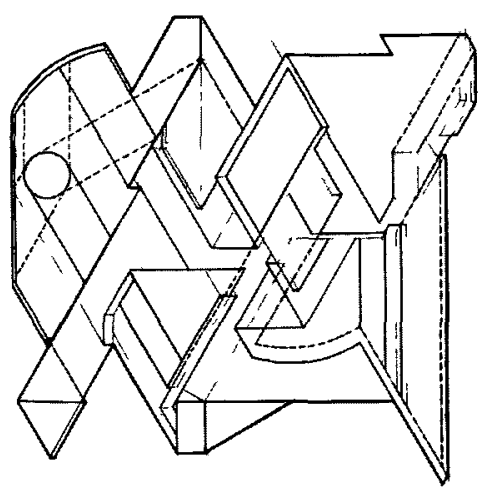

VI I

PLAN-CUT AXONOMETRIC AT COLUMN. 


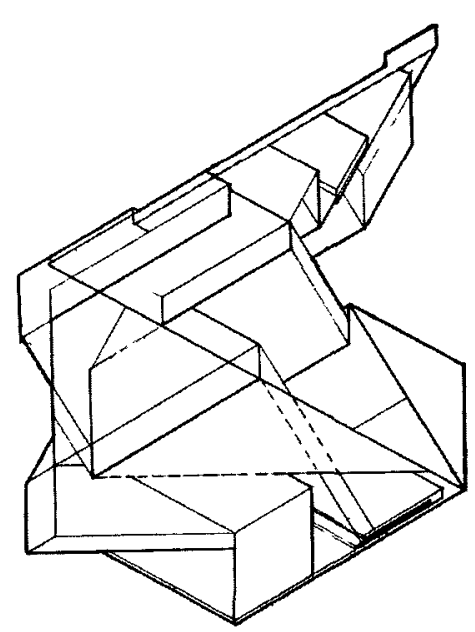

VI I I

OVERLAPPING TRANSPARENCIES.

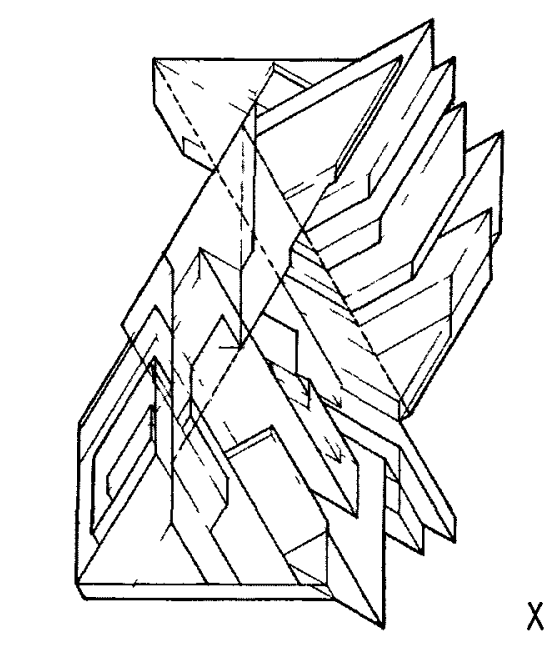

WORKING WITH ALL ANGLES OF THE

TRIANGLE, ACUTE/OBTUSE ANGLES.

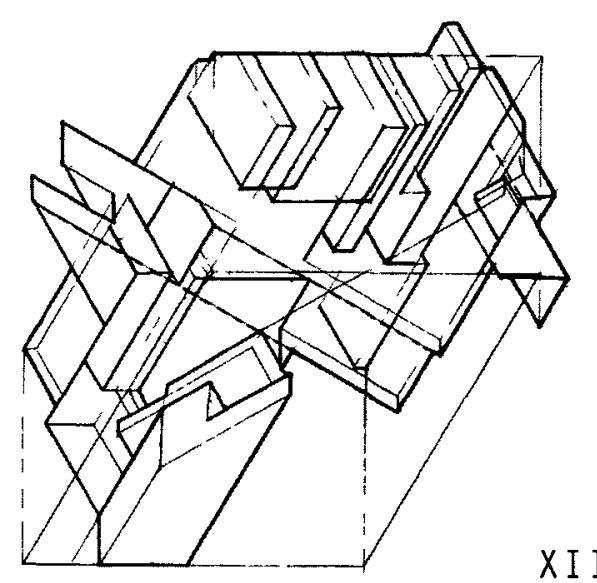

RECTANGULAR CONTAINMENT

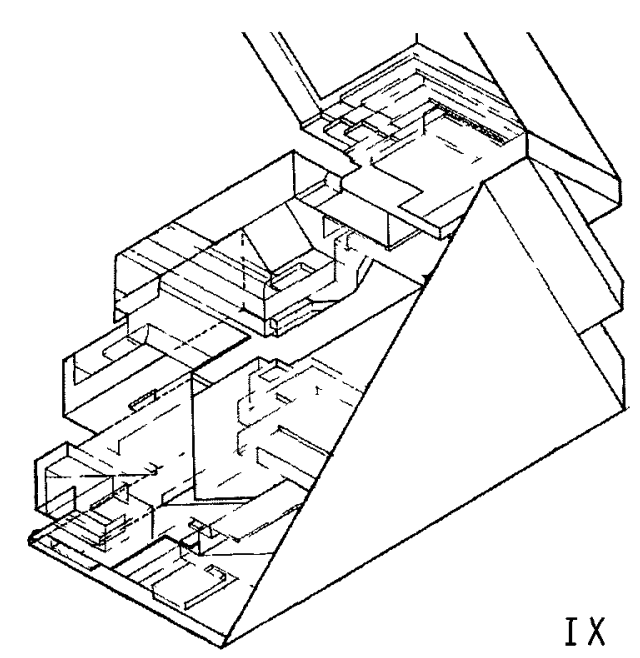

FOREGROUND OPACITIES.

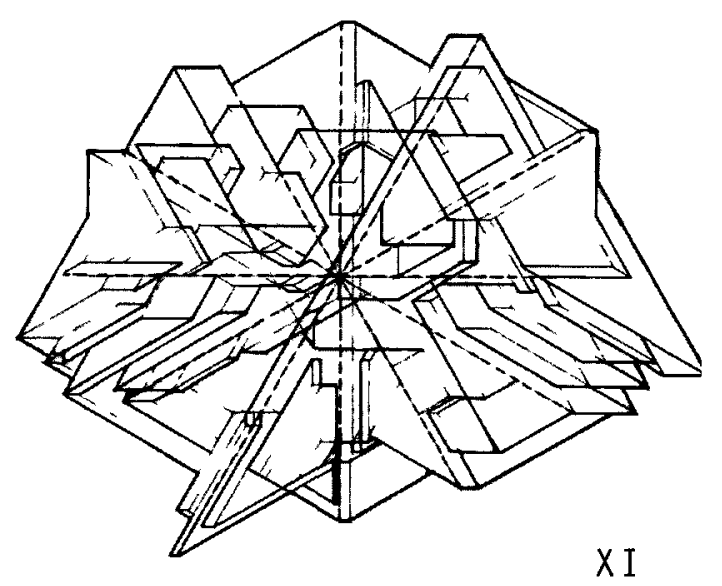

EXTENSIONS FROM CENTRAL AXIS POINT

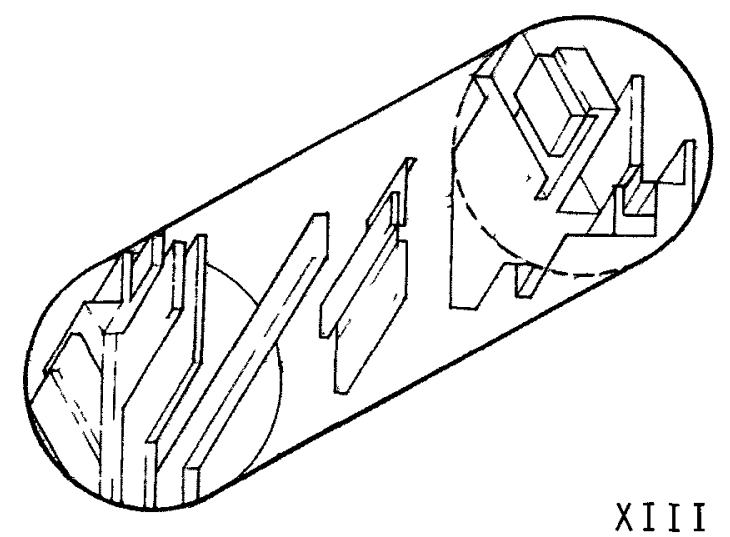

CYLINDRICAL CONTAINMENT . 


\section{PROLOGUE}

\section{Imaginat ive Space DeVelopment Through \\ THE USE OF AXONOMETRY}

Architecture exists in a self referential world rich with methodologies of architectural representation and development, so much so, that alternative methodologies of drawing representation and design development can be developed through the current, established and practiced methodologies.

The axonometric drawing is of particular interest. Traditionally, architectural axonometric projections are utilized as a formal presentation technique, often generated from two-dimensional drawings of a finished design. These projections are a simple way of representing a three dimensional object, keeping the elements to scale and showing the relationship between several sides of the same object, so that the complexities of a shape can be clearly understood. Most often, the axonometric drawing's role in architectural practice is as a formal representation and communication tool of a finished design or idea and rarely, or only recently, as a tool for generating speculative, imaginative spaces that contribute to the ideas and design of architecture.

How can we raise the status of the axonometric drawing above mere descriptive or predictive functions? Predictive design drawing methods often result in predictable buildings, where the building is projected as a scaled-up version of the architect's drawings and/or models. Can we not challenge current axonometric drawing practices in architectural representation by developing an alternative methodology of axonometric drawing that acts as a generator for space, form, ideas and design through the provocation of one's imagination? Is it not possible to develop drawings and/or models that cannot simply be scaled up in an effort to adopt a critical stance? And how would such a development inform space de-

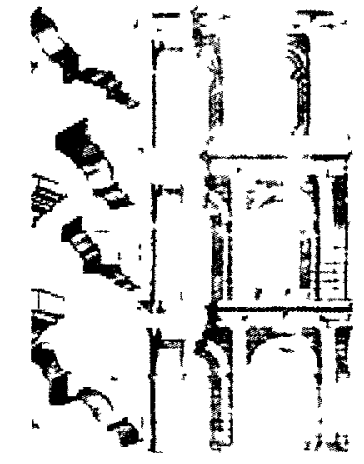

FIG 3 THE FIVE BOOKS ON ARCHITECTURE (1611) SEBASTIANO SERLIO

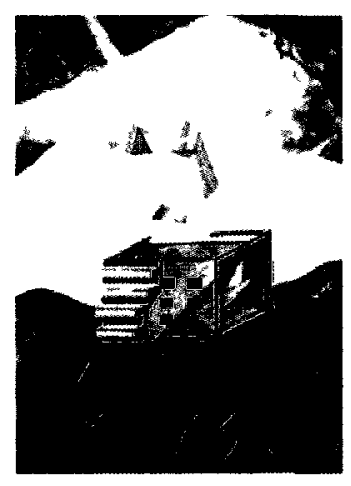


velopment and/or architecture? Is it possible to prepare a methodology through which traditional architectural drawings such as plans, elevations and sections can later be translated into a comprehensible architecture? How can architectural ideas in turn, be influenced by the axonometric drawing? The inquiry is to investigate an alternative methodology for creating space, form and architecture that is no less significant than that of traditional practice. This alternative use could challenge the way we make space, form and architecture, as well as the tools we use to do so, and the way in which we use them. It is obvious however, that the evaluation is subjective, but it is also understood that subjectivity is a basis of conceptual thinking in architecture's field of operations; is unavoidable and therefore should be celebrated as an essential element in the evolution of the architectural discourse, informing architecture in multiple diverging ways, each of which capable of revealing new discoveries.

Exercises within this thesis will explore the process of 'imaginative space development through the use of axonometry', rather than the more conventional and familiar process of axonometry as a means of representation. Building models derived from generative axonometric drawings allow for the construction of speculative spaces and could further generate design through the process of materiality and making. The outcome is not solely focused on the production 'of' architecture. Rather, the process itself becomes a means 'towards' architecture. 


\section{INTRODUCT I ON}

To speculate is to form a theory or conjecture about a subject without firm evidence. The title Speculations refers to the conceptual and spatial dimensions formed by, and explored through, subjective interpretations and pre-determinations of an inquiry. Speculations act to challenge perceptions by provoking the subconscious to bring forth an understanding, definition and order to the visual chaos. Such 'dimensions' are speculative because they are unique to the subject's perception of the inquiry. And perceptions are unique to the individual because they continuously evolve through the association of one's experiences and acquired knowledge. Those who inquire just 'what' the Speculations 'are,' can have no correct or incorrect determination; as they are open to the exploration of subjectively perceived interpretations and determinations. This process intends to bring forth potential interpretations and definitions of these drawings, and to speculate on the potentials they offer to the architectural realm.

At the beginning of this process, axonometric illusions become a graphic medium for revealing design associations, quick notations of ideas and a field of research from which better understandings, between the designed object and its field of operations, can develop. The role of an axonometric projection as a final presentation drawing in a project is not in doubt. Far more complex, I would argue, is its importance throughout the design process. During such a process the axonometric illusion is translated into allusions of architecture with physical model interpretations of the perceived, illusory spatial relations. Axonometric

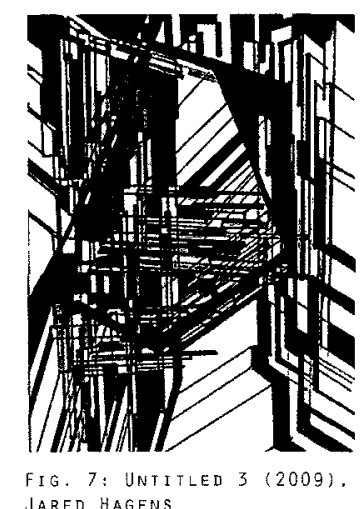
drawing can act as an imaginative design generation tool, as opposed to its traditional role as a post-design representational tool.

These initial manipulated axonometric drawings (Speculations) are in fact diagrams. And all the models, research and writings developed to further understand their potential abilities are contained within the interiorities of these diagrams. The question posed then, is whether through exteriorities or rather, through the influences of a desired outcome, we can expose anterior and interior traces of architecture within the diagrams? If so, it is possible then to view this thesis inquiry in its entirety as a diagram; interior to the very diagrams (Speculations) which it hopes to develop and contextualize. 


\section{THESIS DIAGRAM}

The following diagram is a representation of the inquiries of this thesis, their influences, and potential directions for continuation. The bottom half is a historical timeline of the works of relative artists, architects, engineers, philosophers \& mathematicians divided into four main categories of inquiry; Illusion, Axonometrics, Diagrams \& Models. The timeline's purpose is to contrast and compare the historical developments of each category to reveal potential relationships and visually situate particular references of interest: a visual summary of historical contexts relating to the thesis inquiry. Also, each reference is connected to one of three categories in the top half of the diagram in order to portray their direct role as either an anterior, interior or exterior trace or influence to the development of the thesis. Those connected to the anteriorities column are direct influences and/or contextual reinforcements for the work and ideas leading up to the development of Speculations. Those connected to the interiorities column do the same for the ideas that define Speculations. And those connected to the exteriorities column do so for the application and continuation of the thesis inquires into an architectural project.

All images in the top half of the diagram are linearly connected to represent the development or incorporation of each. In the far left are the precedent drawings and sketches which lead to the development of Speculations. This is followed by connections to case studies such as Peter Eisenman's House VI and the use of diagrams in architecture, to El Lizzitzky's axonometric explorations called Prouns, which further connect the translation of Speculations to models and a systematic continuation of their development into an architectural project proposal.

It should be noted, that although the scope of the diagram has since been superceded by the continued development of the thesis inquiry, it still remains a holistic summary of the core research and influences present throughout this thesis. 


\section{CHAPTER 1 : \\ RESISTING CONVENTIONAL ARCHITECTURE}

\subsection{ARCHITECTURE DRAWINGS}

"Too often, contemporary practice oscillates between mechanical repetition and shallow novelty. Conventional practice renounces theory, but in so doing, it simply reiterates unstated theoretical assumptions... The protocols of normal practice may be modified or adapted in response to circumstance, but are rarely challenged. Design is reduced to the implementation of rules set down elsewhere. If theory imposes regulated ideological criteria over the undisciplined heterogeneity of the real, the unstated assumptions of conventional practice enforce known solutions and safe repetitions." - Stan Allen ${ }^{1}$

Too often, as in any design practice, contemporary methods fluctuate between mechanical repetition and weak conceptual context. In Practice: Architecture Technique + Representation, Stan Allen argues that "conventional practice renounces theory, but in so doing, it simply reiterates unstated theoretical assumptions...the protocols of normal practice may be modified or adapted in response to circumstances, but are rarely challenged." ${ }^{2}$ Thus, as Allen notes, most design methods are reiterations or derivatives of widely accepted rules set down elsewhere. This is particularly problematic when such rules, particularly in professional practice, are geared towards the safe repetition and standardization of accepted norms for the sake of temporal and economical efficiency. Does this not stunt the progressive potentials of experimental thought?

The architectural profession, particularly through the increase of legal responsibilities and actions, relies on the safety of standard practices to avoid the associated risks. Very few firms can afford to experiment with unproven materials or practices due to the lack of insurance coverage or funds, to minimize risk through hiring specialized consultants. This results in the formation of accepted and predictable status quos and industry developed products and investment strategies to ensure safe mutual benefit to all parties. 
It is the architectural drawing that fuels the industry, as an assemblage of spatial and material notations that can be decoded into a script or set of instructions that direct the selection of products necessary for the realization of a building. ${ }^{3}$ It can also be argued that conventions are a necessity to industry because architectural drawings require products to notate and vice versa, product development depends on the notations in drawings. In this peculiar perspective, the advances in product development rely on updating conventional practices to alter the standard notations in architectural drawings; particularly when architectural design programs such as Building Information Modeling (BIM) develop standard material libraries to aid the entire design and development process of a project. It is arguable then that if standard architectural conventions evolve according to the demands of industrial advancements and vice versa, then challenging architectural representational conventions could potentially provoke the industry to respond accordingly.

Referencing Allen again, architectural design operates on a rich basis of abstract codes and complex instrumentalities rich with methodologies; these hold the capacity to spawn new and/or alternative poetic translations of representation. ${ }^{3}$ There is ample historical evidence showing how drafting techniques provide the architect with sets of graphic analogies that allow them to perform their thought-experiments. Marco Frascari in From Models to Drawings, refers to this relationship as "Working from a 'great un-digital database' of instinc-

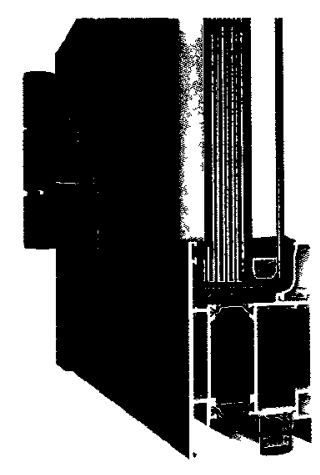
FIG 10 CS 77 FF EIGO DOOR DETAIL REYNAERS ALLUMINUM tive information picked up from experiences...architects have worked out their thought-experiments on paper, discovering something new about the built world even though they have no new data. ${ }^{15}$ These same codes or graphic analogies according to Allen, allow the architect to detach from, and "structure internal relationships" with their designs, in order to provide a sense of operational freedom when moving in visible and invisible realms. ${ }^{6}$ 
In relation to the development and elaboration of architectural theories, architectural drawings are most often exploited as mere graphic reinforcements, according to Frascari, without the realization that such drawings, "carry embodied in them the non-verbal essence of architectural theory." ${ }^{\text {7 }}$ Even in their most conventional forms, architectural drawings hold the capacity to inspire discovery and originality beyond the confines of their normative operations. This, however, is dependent upon the imaginative ability of the designer to assimilate and creatively reiterate drawing conventions and operations in order to overcome conventional confinements. Doing so can potentially unlock the inspirational possibilities interior to time-honored architectural representations. ${ }^{8}$ Thus,

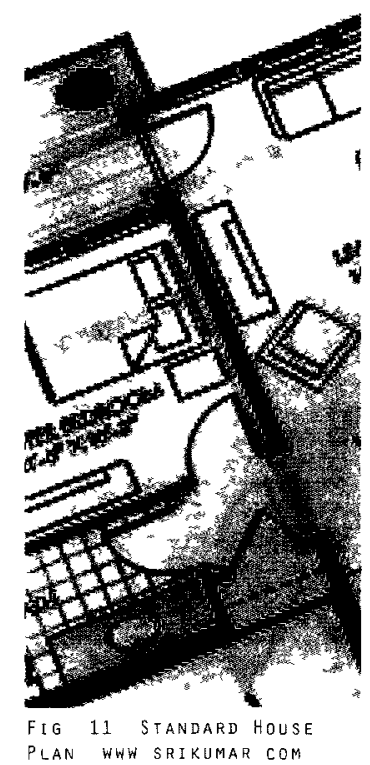
architectural drawings are not merely formal instruments for the representation of objects, but essential methodologies capable of manifesting new modes of thought toward architectural production.

Allen, Stan "Practice Archıtecture, Technıque + Representation" XII, Routledge, 2009 (New York) 2 ıbıd, Allen Xu

3 ibid, Allen p 41

4 ibıd, Allen $p 75$

5 Frascarı, Marco "Models and drawings - the invisible nature of architecture' Op cit, From Models to Drawings, $p 4$

6 ıbıd, Allen p 75

7 lbıd, Frascarı p 5

8 El Bizri, Nader "Imagination and Architectural Representations" Op cit , From Models to Drawıngs, p 35 


\section{2 Speculations: Restraining Bim}

"...in the light of the new possibilities generated by the use of electronic media, a different and passionate challenge of these immobile and sterile circumstances is needed to alter the present perception of the nature, skills and means that govern the conceiving and making of architectural models and drawings." -Marco Frascari ${ }^{1}$

\section{Building Information Modeling's (BIM) popularity is rapidly increasing in} the design and construction industry as a growing number of professionals are embracing its advantages. BIM changes the way project teams work together, allowing them to collaborate on a single model to increase productivity, minimize errors and ultimately, provide financial benefits to all members. Architects however, must remain wary of solely using the BIM system for the design development process as, with any software, there are programmatic limitations that can hinder the architect's creative processes. BIM software is pre-programmed to perform given design tasks and therefore is incapable of going beyond the limitations of its programming. Thus the concern is how such limitations affect the architect's design creativity or, more subversively, aim to control and impose

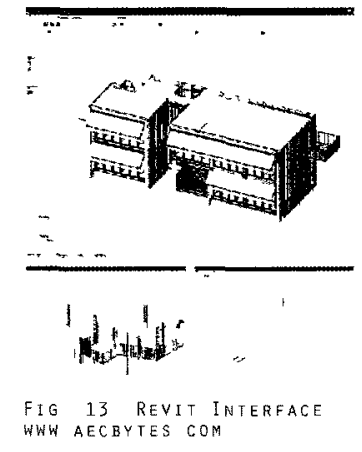
creative standards for the architect's use. As a relatively novel technology, BIM justifies these shortcomings by claiming to still be under development: of course as the complexity of BIM increases, so will the user's ability to utilize it. But if a user's software knowledge is always limited, so will be their ability to realize complex design intentions, potentially resulting in intellectual and creative inertia which favours developing easier design solutions using the imposed design standards available rather than developing better solutions that reach beyond the user's BIM abilities.

Architects have a responsibility to contribute to the progression and improvement of the world but, by designing within the realm of BIM technology 
alone, they may simply be reinforcing accepted standards, resisting the creative ingenuities and explorations (inherent to traditional architectural analogue techniques) which lead to new operational or theoretical discoveries. It is possible to demonstrate how BIM software is a graphic tool that mimics accepted architectural representation standards, limiting the creative depth and explorations necessary for architects to make new and important architectural discoveries. This thesis proposes that through illustrations, we demonstrate how traditional analogue axonometric techniques in combination with visual illusion techniques, can be developed into a design methodology capable of directly challenging such restraints, thereby emphasizing the progression of analogue techniques as a necessity for the progression of BIM systems.

As introduced earlier, architecture exists in a self-referential world rich with methodologies of architectural representation and development, enough indeed that alternative methodologies of drawing representation and design development can be developed through currently established and practiced methodologies. In recent years, BIM systems have adopted this very role, using existing practice standards to provide new and improved collaborative, threedimensional project development methodologies that often result in saving time and money and, in many cases, foresee potential errors in a project's design and construction. The focus here is not intended to positively or negatively situate BIM. We must all accept that BIM is here to stay and our roles should no longer simply debate the positives and negatives of its integration in the profession. Rather, can we challenge its inherent programmatic limitations and discover where improvements can be made? This is particularly crucial for the design development process as most often this is when key ideas, themes, concepts, strategies and/or visual massing are introduced. Importantly, this is also where 
one teeters with the decision to accept given standards, or to make an effort to contribute (no matter how minimally) to the progressive evolution of architectural methodologies.

But how does one contribute? To address this, I call into question the role of axonometric representation in conventional practice. If, as discussed previously, we raise the status of the axonometric drawing above mere descriptive or predictive functions in an effort to challenge conventional practice, it may be argued that developing a new architectural methodology is a direct challenge to the program limitations of mimicked architectural representation standards and uses found in BIM systems. The role of axonometric drawings in architectural practice is often as a formal representation and communication tool of a finished design or idea vs. a tool for generating design and ideas. And contemporary development of axonometric representation through the use of BIM systems arguably reinforces the former; meaning BIM may be able to provide seductive delusions of three-dimensionality and an ability to generate virtually limitless viewpoints of an object at any desıred scale, but still remains dependant on prior design efforts such as standard geometric masses or a plan to situate and direct their presence and continual formation. ${ }^{2}$

Thus, these are the consequential results of pre-determined actions permitted by a system's programming. Marco Frascari reinforces this in From Models to Drawings stating, "In thıs digital BIM system, when the architect draws what is actually taking place within the shadows of the digital machine (hidden from the architects' physical and mental senses), is that objects are being created in a database within an extensive array of standardized properties. This information is used to generate 'drawings', but it is used in many other ways as well, fulfilling the pseudo-proficient dream of a professional efficiency". ${ }^{3}$ Unfortunately however, the relative ease and time saving ability for generating axonometric projections with BIM (in comparison to analogue drafting) reinforces their popu- 
larity and often conceals its limitations to the user.

Although one cannot refute the many advantages of BIM to provide virtually any desired perspective of a given object, one has to be wary of the implications. By being able to produce any selective view, the user sacrifices the ability of traditional analogue drawings to force an awareness of the unseen objects (in) behind the opacities of objects. This results in an amnesic design approach where limitless vantage points prevent the architect from selecting and refining what is important for conveying the architectural intentions. By comparison, the opacities of the traditional analogue drawings force the architect to be aware of what is not shown and to determine which views most efficiently and holistically convey a coherent understanding of key ideas; characteristic and skill that is far more valuable to architecture than that of a series of shallow images.

Stan Allen references T.S. Kuhn in Practice: Architecture, Technique + Representation, stating that architectural practices necessarily respect the laws that govern matter and forces, while also recognizing that the very same laws “operate without regard to consistency or established conventions of rational expression." ${ }^{4}$ It is the recognition of these inconsistencies between theory and realities where attentive explorations can challenge known conventions and pro-

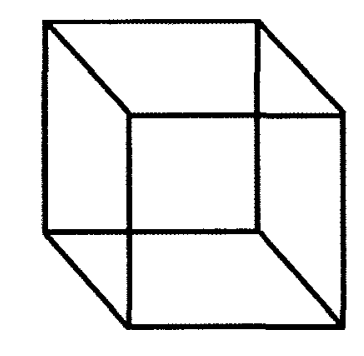

FIG. 19: NECKER CUBE (1832), LOUIS ALBERT NECKER duce new theories. It is important then to recognize that elevating the role of the axonometric is only achievable by continually reworking the limits of axonometric techniques and methodologies from within. It is also important to recognize the impossibility to effectively operate outside the axonometric 'field of operations,' and to understand that careful attention to how one can push the basic fundamentals of axonometric techniques is necessary in order for the drawing to question accepted methodologies. Further, one must begin to draw; for it is by the continual advancement of an idea through the logic and working procedures of architecture that new concepts can generate and call conventions into question. ${ }^{5}$

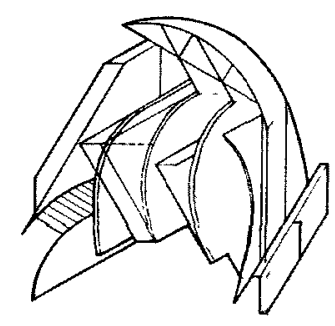


Through the use of illusionary qualities, Speculations utilizes both the analogue and digital techniques as 'hybrid representations' with the advantages found in both. For example, the overlapping of lines and planes in Speculations creates a Necker cube effect, where transparency allows the perceived positioning of forms to shift or inverse. This effect simultaneously represents unlimited potential views but forces the observer to select how they wish to perceive forms in relation to one another. The use of architectural drafting conventions such as dashed and varied line weights provide the illusion of depth and positioning to help guide the viewer's selection through visual cues; cues which hint at a given form which only the participant's imagination is capable of completing. This enables the participant's imagination to be at play with their visual perception and contemplative, discerning intellection ${ }^{6}:$ This allures the viewer to want to accept their spatial potentials, only to realize such potentials teeter on the edge of impossibility.

Abstraction and architectural line weight/type drafting techniques were of key importance in the development of representations capable of provoking visual engagements for the imagination of speculative spaces. Abstraction is important of course: "In the process of drawing away from experienced reality, abstraction is the basis of interpretation and expression in the process of forming architecture. To abstract is to select, to select is to make a choice, to choose one thing is to disregard others. In the simple process of selection, ideological positions are revealed." ${ }^{17}$ Such a process is true, evident in the Speculations which conveys what Alberto Perez-Gomez refers to in Questions of representation: The Poetic Origin of Architecture, as the 'first dimension;' a realm that remains mysterious and "reminds us of our luminous opacity as mortals in a wondrous morethan-human world." ${ }^{8}$ The complexity and incoherence of the abstracted multiparalleled architectural axonometric and the models produced, cannot simply be scaled up. The drawing therefore adopts a critical stance, informing space
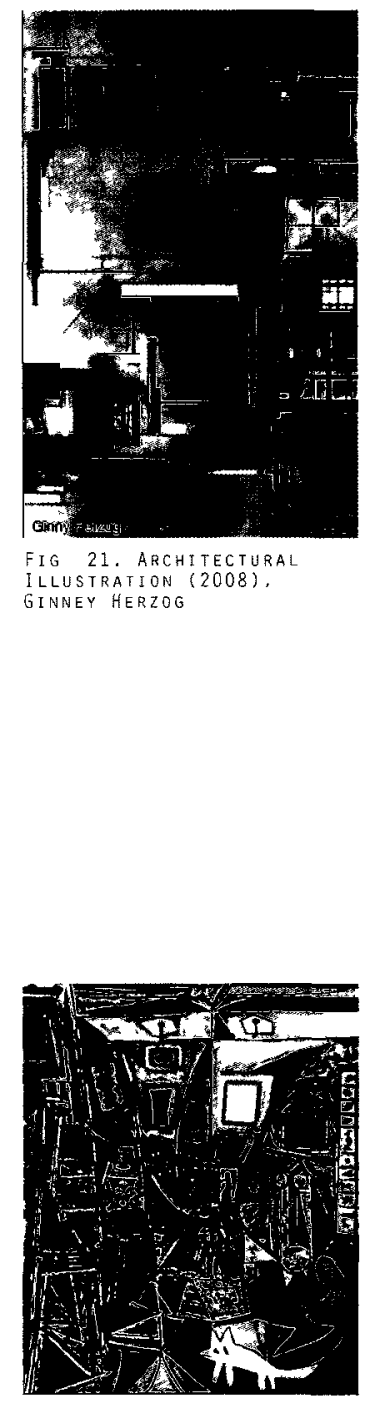
F1G. 22: LAS MENINAS
(1957). PABLO PICASSO

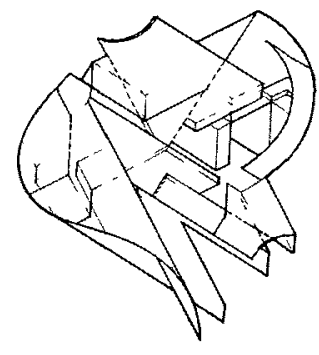
FIG 23. SPECULATION
$(2010)$ JARED HAGENS 
development and/or architecture in multiple and diverging ways. These abilities are in stark contrast to BIM programming which can stifle the pursuit of invisible potentials.

These Speculations begin to challenge current axonometric drawing practices in architectural representation by an alternative methodology of axonometric drawing that acts as a generator for space, form, ideas and design through the provocation and manipulation of one's imagination. The spatial determinations one generates can then be brought forward or translated into physical or digital models, allowing for the production of an architectural project in BIM stemming from the spatial interpretations (from the imagination) as opposed to according to the standardizations of BIM programming. Utilizing such design references could motivate and challenge users to improve upon their BIM abilities in an effort to more effectively develop their spatial imaginative capacities. Such actions resist the risks of simply developing BIM architecture, and would promote challenging the utilization of BIM to work toward architecture.

\footnotetext{
1 Frascarı, Marco "Models and drawings - the invisıble nature of architecture" Op cit, From Models to Drawings, p 2

2 Perez Gomez,Alberto "Questions of representation The poetic origin of architecture" Op cit , From Models to Drawings, eds Marco

Frascan, Jonathan Hale and Bradley Starkey, p 21, Routledge (UK/New York) 2007

3 lbıd, Frascarı $p 3$

4 Allen, Stan "Practnce Architecture, Technıque + Representation 'XII, Routledge, 2009 (New York)

5 Ibıd, Allen p XII

6 El Bizrı, Nader "Imagınation and Architectural Representations" Op cit , From Models to Drawings, p 35

7 Hamel, Catherıne "Drawings lines of confrontation" Op cIt , From Models to Drawings P 206

8 Perez Gomez,Alberto "Questions of representation The poetic origin of architecture" Op cit , From Models to Drawings, p 21
} 


\subsection{COSMOPOIESIS}

\author{
"Cosmopoiesis, or world making, always starts from a world already at \\ hand; the making is remaking." -Marco Frascari ${ }^{1}$
}

For centuries, contributions from architects, artists, builders and engineers alike, has developed numerous drafting and representation methodologies and applications influencing architectural development. Architecture has diverged as an independent stream of study and professional practice with a world of reference containing methodologies capable of facilitating new form. The development of new architectural methodologies, however, must first undergo a process of cosmopoietic development, experimentation and standardization until proven as a worthy asset for architectural practice. It is through the act of cosmopoiesis that new or alternative methodologies of architectural development can further evolve the self referential world of architecture.

The architect creates worlds through drawings but, most often, the drawings conform to current standard methods of architectural practices, reinforcing proven methodologies instead of challenging them. Although the architecture drawn is unique to its creator, the unchallenged utilization of methodologies of architectural development results in architectures subject to the limited world of reference of the methodologies used. If an alternative methodology for architectural creation and representation were used however, a new world of reference would result, evolving (as opposed to conforming) architecture's selfreferential world through the act of cosmopoiesis.

The notion of evolving is of key importance because it infers development of the existing 'world already at hand'. In regards to architectural generative and representative drawing techniques, such methodologies are destined to evolve in parallel to their social and technological climates. There are however, specific moments that can initiate or push the evolutionary process; a moment of catharsis that can enlighten and bring forth change to a current state of un-

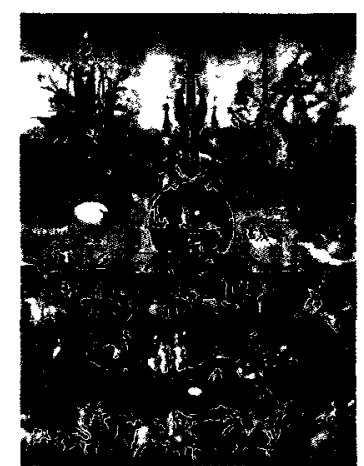

FIG. 24. THE GARDEN OF EARTHLY DELIGHTS. CENTRAL PANEL OF TRIPTYCH (1504). HIERONYMUS BOSCH

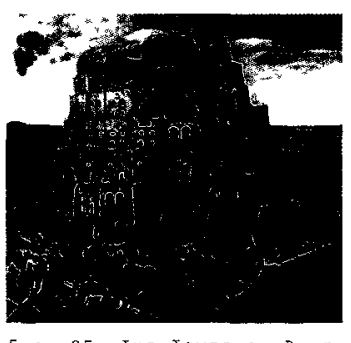

FIG. 25. THE TOWER OF BABEL (1563), PIETER BRUEGEL 
derstanding. For example, in the architectural world of reference, the discovery of perspective provided, for artists and architects, a new and far more realistic technique for representing the natural and built world; a new set of knowledge from which other methods of perspective representation, such developed as three-point perspective. Perspective was the cosmopoietic root for the development of three-point perspective.

Let us consider the time and space between the discovery of perspective and its evolved form of three-point perspective. This 'between space,' was on the verge of evolving through cosmopoietic acts of experimentation and the development of perspective techniques. The architecture produced with perspective techniques during this time was, once again, limited until the next evolutionary turn. Like any architectural representation technique, three-point perspective needed first to be standardized for architectural practice, requiring a proven set of guidelines and rules for accurate, replicable production. Such standardizations result in developed methodologies easily applicable to architectural development and, when accepted in the architectural community as such, the world of reference of architectural drawing evolved. The conformed utilization of conventional drawing techniques for architectural production result in architecture constructed in an intermediary state; in the in-between space that the methodologies inherently provide. Speculations is one such attempt to break out from 'between' in search of a new world of reference.

In architecture's current technical drawing world of reference, drawing methodologies can be divided into two categories: multi-view drawings and single-view drawings. Plan, elevation, and section drawings are multi-view drawings where several coordinated images are necessary to visually facilitate the overall form and understanding of the object. Single view drawings however, are threedimensional projections where one drawing ilfustrates several surfaces of the object, facilitating the understanding of the overall form of the object. ${ }^{2}$ Central perspective and parallel projection are the two systems of single-view drawing that are capable of portraying the three-dimensional nature of an object.

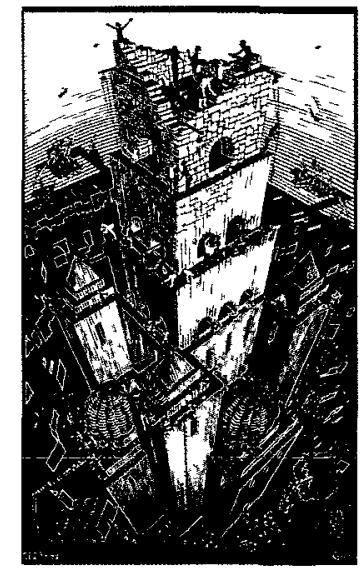

FIG 28 TOHER OF BABEL SPECTIVE) MC ESCHER 
As a development of single-view axonometric drawings, it can be argued that Speculations retain the ability to portray architecture more accurately and holistically due to the ability to combine plan, elevation, and section in one three-dimensional drawing where lines are drawn to scale. M. Saleg Uddin confirms this in Axonometric and oblique drawing : a 3-D construction, rendering and design guide, stating: "The Primary characteristics of axonometric projection are the inclined position of the object with respect to the plane of projection. Since the principle edges are inclined to the plane of projection, the lengths of the lines, the size of the angles, and the general proportions of the object vary in an infinite number of proportions." ${ }^{3}$ For illustrating the interior information of an object or building in context to the exterior form or spatial enclosure, axonometric drawings provide numerous options in their range of types and techniques of presentation. For analyzing a design by its constituent parts, the axonometric drawing offers more effective options than other types of drawings. For example, if one were to view a parallel projection drawing of a cube it would resemble figure 32. From the information provided in this projection, one understands the nature of the object as a whole, and could easily and accurately obtain the plan, section, elevation and perspective of the cube. Obtaining such information from a single drawing stands true to the axonometric. ${ }^{4}$ Both multi-view and singleview drawings may both be techniques resultant of, and a route to, future cosmopoiesis. The axonometric, however, is the most cosmopoietic because it not only provokes imaginative interpretations of an infinite number of proportions but, also, represent the world it creates far more accurately and holistically than other methods of architectural representation.

Marco Frascari states in Models and drawings - the invisible nature of architecture that the drawing process helps to "invent better futures and make potential worlds." ${ }^{15}$ Architects are at the forefront of progress as they are responsible for specifying how future objects are made to exist. By producing architectural drawings, architects treat the imagined future as real and provide a means to manifest their physical existence. This, according to Frascari, is "an

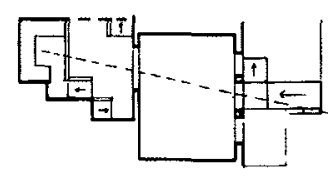

Fig. 29: Muller house plan

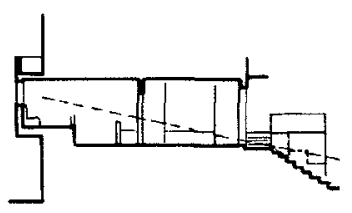
FIG. 30: MULLER HOUSE SECTION

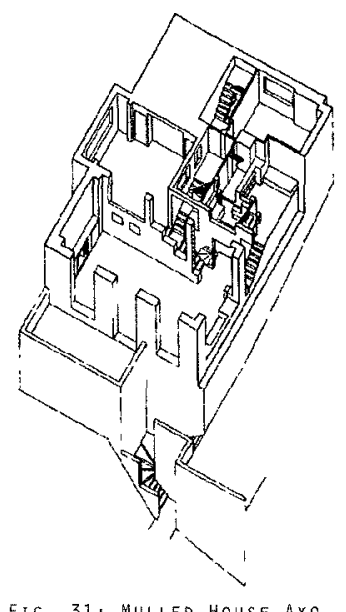

Fig. 31: MULLER HOUSE AXO (1928). ADOLF LOOS

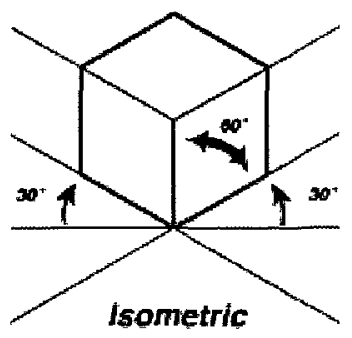

Fig. 32: ORTHOGRAPHIC CUBE: WORKING WITH ORTHOGRAPHIC PROJECTIONS \& BASIC ISOMET RICS. WWW. ONETUTS.COM 

act of world-making: a cosmographic expression that is also the root to future
cosmopoiesis."
\[ \text { It is important, then, for architects to analyze critically their work from } \]
a cosmopoietic perspective, understanding the positive and negative influences
their works promote: bearing in mind how their works may influence the archi-
tectural developments of future generations. If Cosmopoiesis always starts from
a world already at hand and the making is remaking, then the present actions
of architects are directly related to the actions of those before them and those
still to come. Therefore it is important for the architect to promote architectural
standards through practicing cosmopoietic acts that resist conforming to the ac-
cepted conventional norms.
this movement and, like Speculations, they were experiments using axonometric
representational techniques. Lissitzky was attracted to the axonometric because
of its ability to transmit simultaneously abstract information and often a measur-
artists of the early twentieth century attempted to move beyond art's traditional
interesting and potentially better future outcomes. Similarly, the revolutionary act of world-making: a cosmographic expression that is also the root to future
cosmopoiesis."
\[ \text { It is important, then, for architects to analyze critically their work from } \]
a cosmopoietic perspective, understanding the positive and negative influences
their works promote: bearing in mind how their works may influence the archi-
tectural developments of future generations. If Cosmopoiesis always starts from
a world already at hand and the making is remaking, then the present actions
of architects are directly related to the actions of those before them and those
still to come. Therefore it is important for the architect to promote architectural
standards through practicing cosmopoietic acts that resist conforming to the ac-
cepted conventional norms.
this movement and, like Speculations, they were experiments using axonometric
representational techniques. Lissitzky was attracted to the axonometric because
of its ability to transmit simultaneously abstract information and often a measur-
artists of the early twentieth century attempted to move beyond art's traditional
interesting and potentially better future outcomes. Similarly, the revolutionary act of world-making: a cosmographic expression that is also the root to future
cosmopoiesis."
\[ \text { It is important, then, for architects to analyze critically their work from } \]
a cosmopoietic perspective, understanding the positive and negative influences
their works promote: bearing in mind how their works may influence the archi-
tectural developments of future generations. If Cosmopoiesis always starts from
a world already at hand and the making is remaking, then the present actions
of architects are directly related to the actions of those before them and those
still to come. Therefore it is important for the architect to promote architectural
standards through practicing cosmopoietic acts that resist conforming to the ac-
cepted conventional norms.
this movement and, like Speculations, they were experiments using axonometric
representational techniques. Lissitzky was attracted to the axonometric because
of its ability to transmit simultaneously abstract information and often a measur-
artists of the early twentieth century attempted to move beyond art's traditional
interesting and potentially better future outcomes. Similarly, the revolutionary act of world-making: a cosmographic expression that is also the root to future
cosmopoiesis."
\[ \text { It is important, then, for architects to analyze critically their work from } \]
a cosmopoietic perspective, understanding the positive and negative influences
their works promote: bearing in mind how their works may influence the archi-
tectural developments of future generations. If Cosmopoiesis always starts from
a world already at hand and the making is remaking, then the present actions
of architects are directly related to the actions of those before them and those
still to come. Therefore it is important for the architect to promote architectural
standards through practicing cosmopoietic acts that resist conforming to the ac-
cepted conventional norms.
this movement and, like Speculations, they were experiments using axonometric
representational techniques. Lissitzky was attracted to the axonometric because
of its ability to transmit simultaneously abstract information and often a measur-
artists of the early twentieth century attempted to move beyond art's traditional
interesting and potentially better future outcomes. Similarly, the revolutionary act of world-making: a cosmographic expression that is also the root to future
cosmopoiesis."
\[ \text { It is important, then, for architects to analyze critically their work from } \]
a cosmopoietic perspective, understanding the positive and negative influences
their works promote: bearing in mind how their works may influence the archi-
tectural developments of future generations. If Cosmopoiesis always starts from
a world already at hand and the making is remaking, then the present actions
of architects are directly related to the actions of those before them and those
still to come. Therefore it is important for the architect to promote architectural
standards through practicing cosmopoietic acts that resist conforming to the ac-
cepted conventional norms.
this movement and, like Speculations, they were experiments using axonometric
representational techniques. Lissitzky was attracted to the axonometric because
of its ability to transmit simultaneously abstract information and often a measur-
artists of the early twentieth century attempted to move beyond art's traditional
interesting and potentially better future outcomes. Similarly, the revolutionary act of world-making: a cosmographic expression that is also the root to future
cosmopoiesis."
\[ \text { It is important, then, for architects to analyze critically their work from } \]
a cosmopoietic perspective, understanding the positive and negative influences
their works promote: bearing in mind how their works may influence the archi-
tectural developments of future generations. If Cosmopoiesis always starts from
a world already at hand and the making is remaking, then the present actions
of architects are directly related to the actions of those before them and those
still to come. Therefore it is important for the architect to promote architectural
standards through practicing cosmopoietic acts that resist conforming to the ac-
cepted conventional norms.
this movement and, like Speculations, they were experiments using axonometric
representational techniques. Lissitzky was attracted to the axonometric because
of its ability to transmit simultaneously abstract information and often a measur-
artists of the early twentieth century attempted to move beyond art's traditional
interesting and potentially better future outcomes. Similarly, the revolutionary act of world-making: a cosmographic expression that is also the root to future
cosmopoiesis."
\[ \text { It is important, then, for architects to analyze critically their work from } \]
a cosmopoietic perspective, understanding the positive and negative influences
their works promote: bearing in mind how their works may influence the archi-
tectural developments of future generations. If Cosmopoiesis always starts from
a world already at hand and the making is remaking, then the present actions
of architects are directly related to the actions of those before them and those
still to come. Therefore it is important for the architect to promote architectural
standards through practicing cosmopoietic acts that resist conforming to the ac-
cepted conventional norms.
this movement and, like Speculations, they were experiments using axonometric
representational techniques. Lissitzky was attracted to the axonometric because
of its ability to transmit simultaneously abstract information and often a measur-
artists of the early twentieth century attempted to move beyond art's traditional
interesting and potentially better future outcomes. Similarly, the revolutionary act of world-making: a cosmographic expression that is also the root to future
cosmopoiesis."
\[ \text { It is important, then, for architects to analyze critically their work from } \]
a cosmopoietic perspective, understanding the positive and negative influences
their works promote: bearing in mind how their works may influence the archi-
tectural developments of future generations. If Cosmopoiesis always starts from
a world already at hand and the making is remaking, then the present actions
of architects are directly related to the actions of those before them and those
still to come. Therefore it is important for the architect to promote architectural
standards through practicing cosmopoietic acts that resist conforming to the ac-
cepted conventional norms.
this movement and, like Speculations, they were experiments using axonometric
representational techniques. Lissitzky was attracted to the axonometric because
of its ability to transmit simultaneously abstract information and often a measur-
artists of the early twentieth century attempted to move beyond art's traditional
interesting and potentially better future outcomes. Similarly, the revolutionary act of world-making: a cosmographic expression that is also the root to future
cosmopoiesis."
\[ \text { It is important, then, for architects to analyze critically their work from } \]
a cosmopoietic perspective, understanding the positive and negative influences
their works promote: bearing in mind how their works may influence the archi-
tectural developments of future generations. If Cosmopoiesis always starts from
a world already at hand and the making is remaking, then the present actions
of architects are directly related to the actions of those before them and those
still to come. Therefore it is important for the architect to promote architectural
standards through practicing cosmopoietic acts that resist conforming to the ac-
cepted conventional norms.
this movement and, like Speculations, they were experiments using axonometric
representational techniques. Lissitzky was attracted to the axonometric because
of its ability to transmit simultaneously abstract information and often a measur-
artists of the early twentieth century attempted to move beyond art's traditional
interesting and potentially better future outcomes. Similarly, the revolutionary act of world-making: a cosmographic expression that is also the root to future
cosmopoiesis."
\[ \text { It is important, then, for architects to analyze critically their work from } \]
a cosmopoietic perspective, understanding the positive and negative influences
their works promote: bearing in mind how their works may influence the archi-
tectural developments of future generations. If Cosmopoiesis always starts from
a world already at hand and the making is remaking, then the present actions
of architects are directly related to the actions of those before them and those
still to come. Therefore it is important for the architect to promote architectural
standards through practicing cosmopoietic acts that resist conforming to the ac-
cepted conventional norms.
this movement and, like Speculations, they were experiments using axonometric
representational techniques. Lissitzky was attracted to the axonometric because
of its ability to transmit simultaneously abstract information and often a measur-
artists of the early twentieth century attempted to move beyond art's traditional
interesting and potentially better future outcomes. Similarly, the revolutionary act of world-making: a cosmographic expression that is also the root to future
cosmopoiesis."
\[ \text { It is important, then, for architects to analyze critically their work from } \]
a cosmopoietic perspective, understanding the positive and negative influences
their works promote: bearing in mind how their works may influence the archi-
tectural developments of future generations. If Cosmopoiesis always starts from
a world already at hand and the making is remaking, then the present actions
of architects are directly related to the actions of those before them and those
still to come. Therefore it is important for the architect to promote architectural
standards through practicing cosmopoietic acts that resist conforming to the ac-
cepted conventional norms.
this movement and, like Speculations, they were experiments using axonometric
representational techniques. Lissitzky was attracted to the axonometric because
of its ability to transmit simultaneously abstract information and often a measur-
artists of the early twentieth century attempted to move beyond art's traditional
interesting and potentially better future outcomes. Similarly, the revolutionary act of world-making: a cosmographic expression that is also the root to future
cosmopoiesis."
\[ \text { It is important, then, for architects to analyze critically their work from } \]
a cosmopoietic perspective, understanding the positive and negative influences
their works promote: bearing in mind how their works may influence the archi-
tectural developments of future generations. If Cosmopoiesis always starts from
a world already at hand and the making is remaking, then the present actions
of architects are directly related to the actions of those before them and those
still to come. Therefore it is important for the architect to promote architectural
standards through practicing cosmopoietic acts that resist conforming to the ac-
cepted conventional norms.
this movement and, like Speculations, they were experiments using axonometric
representational techniques. Lissitzky was attracted to the axonometric because
of its ability to transmit simultaneously abstract information and often a measur-
artists of the early twentieth century attempted to move beyond art's traditional
interesting and potentially better future outcomes. Similarly, the revolutionary act of world-making: a cosmographic expression that is also the root to future
cosmopoiesis."
\[ \text { It is important, then, for architects to analyze critically their work from } \]
a cosmopoietic perspective, understanding the positive and negative influences
their works promote: bearing in mind how their works may influence the archi-
tectural developments of future generations. If Cosmopoiesis always starts from
a world already at hand and the making is remaking, then the present actions
of architects are directly related to the actions of those before them and those
still to come. Therefore it is important for the architect to promote architectural
standards through practicing cosmopoietic acts that resist conforming to the ac-
cepted conventional norms.
this movement and, like Speculations, they were experiments using axonometric
representational techniques. Lissitzky was attracted to the axonometric because
of its ability to transmit simultaneously abstract information and often a measur-
artists of the early twentieth century attempted to move beyond art's traditional
interesting and potentially better future outcomes. Similarly, the revolutionary act of world-making: a cosmographic expression that is also the root to future
cosmopoiesis."
\[ \text { It is important, then, for architects to analyze critically their work from } \]
a cosmopoietic perspective, understanding the positive and negative influences
their works promote: bearing in mind how their works may influence the archi-
tectural developments of future generations. If Cosmopoiesis always starts from
a world already at hand and the making is remaking, then the present actions
of architects are directly related to the actions of those before them and those
still to come. Therefore it is important for the architect to promote architectural
standards through practicing cosmopoietic acts that resist conforming to the ac-
cepted conventional norms.
this movement and, like Speculations, they were experiments using axonometric
representational techniques. Lissitzky was attracted to the axonometric because
of its ability to transmit simultaneously abstract information and often a measur-
artists of the early twentieth century attempted to move beyond art's traditional
interesting and potentially better future outcomes. Similarly, the revolutionary act of world-making: a cosmographic expression that is also the root to future
cosmopoiesis."
\[ \text { It is important, then, for architects to analyze critically their work from } \]
a cosmopoietic perspective, understanding the positive and negative influences
their works promote: bearing in mind how their works may influence the archi-
tectural developments of future generations. If Cosmopoiesis always starts from
a world already at hand and the making is remaking, then the present actions
of architects are directly related to the actions of those before them and those
still to come. Therefore it is important for the architect to promote architectural
standards through practicing cosmopoietic acts that resist conforming to the ac-
cepted conventional norms.
this movement and, like Speculations, they were experiments using axonometric
representational techniques. Lissitzky was attracted to the axonometric because
of its ability to transmit simultaneously abstract information and often a measur-
artists of the early twentieth century attempted to move beyond art's traditional
interesting and potentially better future outcomes. Similarly, the revolutionary act of world-making: a cosmographic expression that is also the root to future
cosmopoiesis."
\[ \text { It is important, then, for architects to analyze critically their work from } \]
a cosmopoietic perspective, understanding the positive and negative influences
their works promote: bearing in mind how their works may influence the archi-
tectural developments of future generations. If Cosmopoiesis always starts from
a world already at hand and the making is remaking, then the present actions
of architects are directly related to the actions of those before them and those
still to come. Therefore it is important for the architect to promote architectural
standards through practicing cosmopoietic acts that resist conforming to the ac-
cepted conventional norms.
this movement and, like Speculations, they were experiments using axonometric
representational techniques. Lissitzky was attracted to the axonometric because
of its ability to transmit simultaneously abstract information and often a measur-
artists of the early twentieth century attempted to move beyond art's traditional
interesting and potentially better future outcomes. Similarly, the revolutionary act of world-making: a cosmographic expression that is also the root to future
cosmopoiesis."
\[ \text { It is important, then, for architects to analyze critically their work from } \]
a cosmopoietic perspective, understanding the positive and negative influences
their works promote: bearing in mind how their works may influence the archi-
tectural developments of future generations. If Cosmopoiesis always starts from
a world already at hand and the making is remaking, then the present actions
of architects are directly related to the actions of those before them and those
still to come. Therefore it is important for the architect to promote architectural
standards through practicing cosmopoietic acts that resist conforming to the ac-
cepted conventional norms.
this movement and, like Speculations, they were experiments using axonometric
representational techniques. Lissitzky was attracted to the axonometric because
of its ability to transmit simultaneously abstract information and often a measur-
artists of the early twentieth century attempted to move beyond art's traditional
interesting and potentially better future outcomes. Similarly, the revolutionary act of world-making: a cosmographic expression that is also the root to future
cosmopoiesis."
\[ \text { It is important, then, for architects to analyze critically their work from } \]
a cosmopoietic perspective, understanding the positive and negative influences
their works promote: bearing in mind how their works may influence the archi-
tectural developments of future generations. If Cosmopoiesis always starts from
a world already at hand and the making is remaking, then the present actions
of architects are directly related to the actions of those before them and those
still to come. Therefore it is important for the architect to promote architectural
standards through practicing cosmopoietic acts that resist conforming to the ac-
cepted conventional norms.
this movement and, like Speculations, they were experiments using axonometric
representational techniques. Lissitzky was attracted to the axonometric because
of its ability to transmit simultaneously abstract information and often a measur-
artists of the early twentieth century attempted to move beyond art's traditional
interesting and potentially better future outcomes. Similarly, the revolutionary act of world-making: a cosmographic expression that is also the root to future
cosmopoiesis."
\[ \text { It is important, then, for architects to analyze critically their work from } \]
a cosmopoietic perspective, understanding the positive and negative influences
their works promote: bearing in mind how their works may influence the archi-
tectural developments of future generations. If Cosmopoiesis always starts from
a world already at hand and the making is remaking, then the present actions
of architects are directly related to the actions of those before them and those
still to come. Therefore it is important for the architect to promote architectural
standards through practicing cosmopoietic acts that resist conforming to the ac-
cepted conventional norms.
this movement and, like Speculations, they were experiments using axonometric
representational techniques. Lissitzky was attracted to the axonometric because
of its ability to transmit simultaneously abstract information and often a measur-
artists of the early twentieth century attempted to move beyond art's traditional
interesting and potentially better future outcomes. Similarly, the revolutionary act of world-making: a cosmographic expression that is also the root to future
cosmopoiesis."
It is important, then, for architects to analyze critically their work from
a cosmopoietic perspective, understanding the positive and negative influences
their works promote: bearing in mind how their works may influence the archi-
tectural developments of future generations. If Cosmopoiesis always starts from
a world already at hand and the making is remaking, then the present actions
of architects are directly related to the actions of those before them and those
still to come. Therefore it is important for the architect to promote architectural
standards through practicing cosmopoietic acts that resist conforming to the ac-
cepted conventional norms.
Speculations are not only inherently cosmographical representations
representational techniques. Lissitzky was attracted to the axonometric because
of its ability to transmit simultaneously abstract information and often a measur-
new worlds. El Lissitzky's Proun series from 1919-1925, was in the forefront of
interesting and potentially better future outcomes. Similarly, the revolutionary able ideal for envisioning a new-world order. ${ }^{8}$

Through his Proun explorations, Lissitzky discovered characteristics interior to the axonometric that departed from conventional axonometric practices and began to convey alternative visual and mental understandings; resulting in cosmopoietic developments that brought forth new ways to visualize and understand art and axonometry.

\footnotetext{
1 Frascarı, Marco "Models and drawings - the invisible nature of architecture" Op cit, From Models to Drawings, p 4

2 Uddın, $M$ Saleg Axonometric and oblique drawing a 3-D construction, rendering and design guide $p 10$

3 ibid, Uddin p 13

4 ibıd, Uddin $p 11$

5 ıbıd, Frascan p 4

6 ibid

7 ibıd

8 Allen, Stan "Practice Architecture, Technıque + Representation" 16, Routledge, 2009 (New York)
}
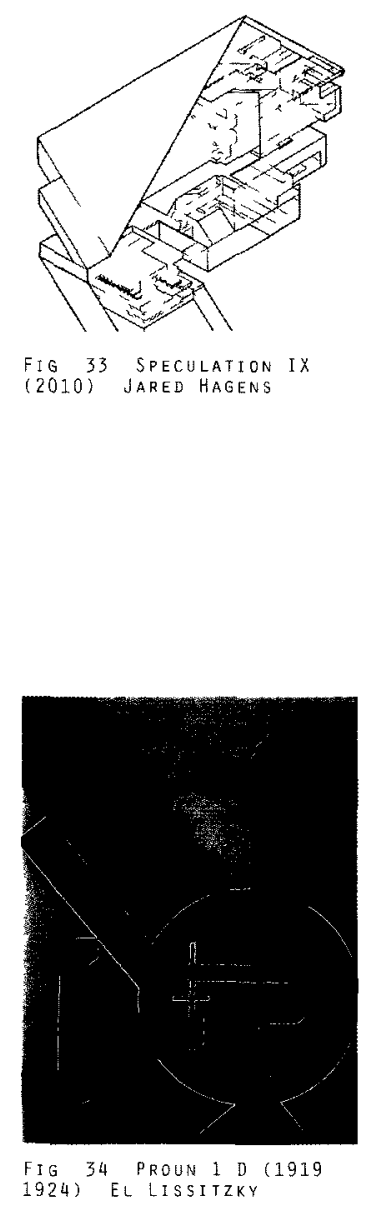

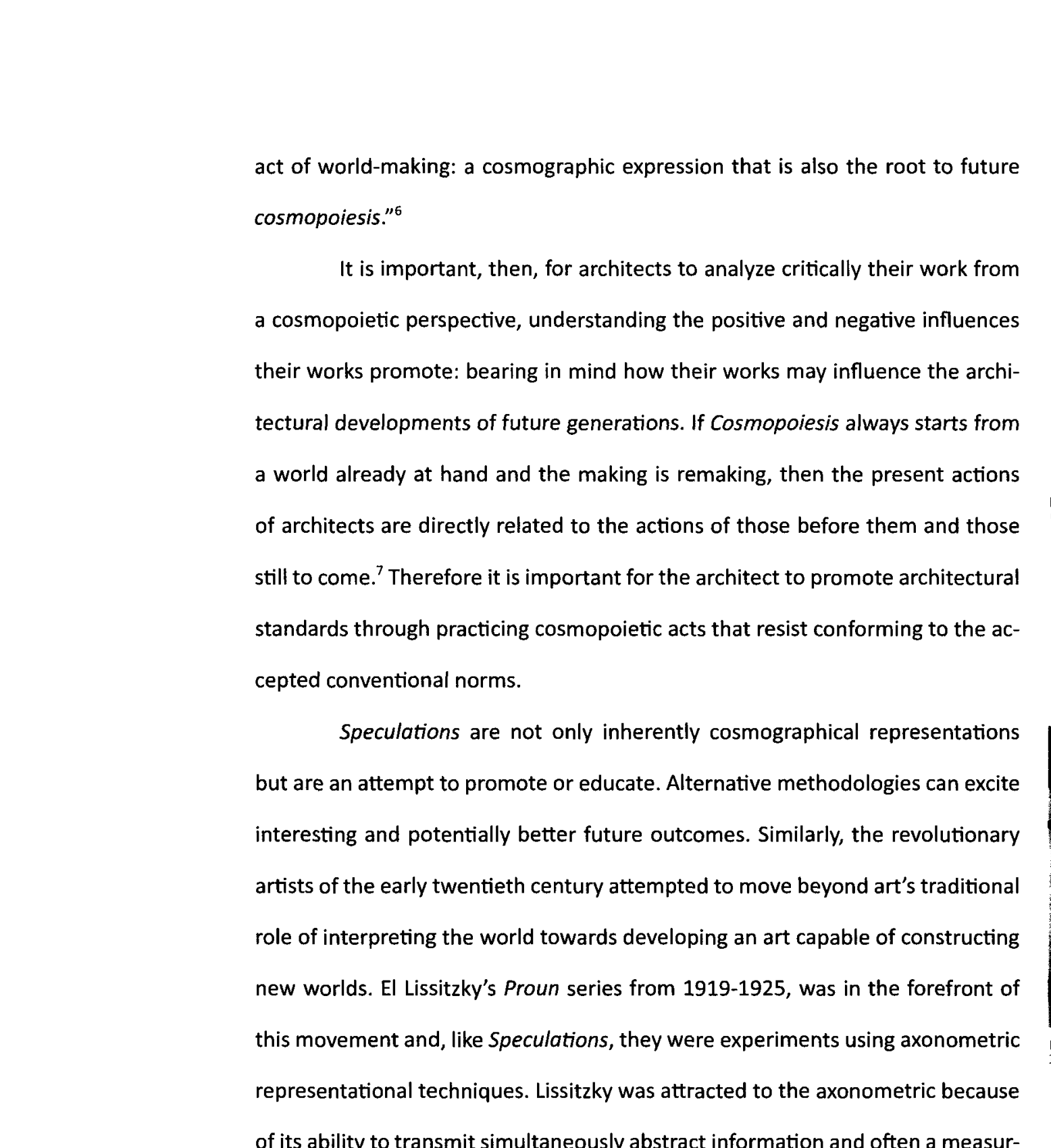




\section{CHAPTER 2 :}

\section{MANIPULATIONS OF THE AXONOMETRIC}

\subsection{PROUNS}

"Proun (pronounced pro-oon) is an acronym for the Russian words for Project for the Affirmation of the New, with which [EI] Lissitzky entitled his work between 1919 and 1927. The collaged and painted forms reconceive space and serve as a metaphor for the fundamental transformations in society that Lissitzky thought would result from the Russian Revolution. In the early 1920s, while many of his colleagues renounced painting, which they viewed as elitist, in favor of utilitarian arts such as furniture and graphic design, Lissitzky remained committed to painting as a means to articulate his utopian vision."

-Museum of Modern Art ${ }^{1}$

El Lissitzky's Proun series was a three-dimensional exploration intended to expand the visual language of Suprematism. At the time, Suprematist concepts were primarily conducted in the two-dimensional realm. Through his Prouns, Lissitzky modeled a socially defined purpose. His visions of Suprematism imagined utopian ideologies for a new and improved world. He wished to go beyond the traditional role of using art to interpret the world to developing an art capable of inspiring new worlds. ${ }^{2}$ This intention led Lissitzky to realize, through a critical lens, the inherent limitations of perspective drawings as a vehicle for abstractly conveying ideologies. This resulted in an attraction to axonometric projection. Lissitzky believed that perspective limited space, making it finite and closed, allowing for only static views (one viewing point) of the world at hand.

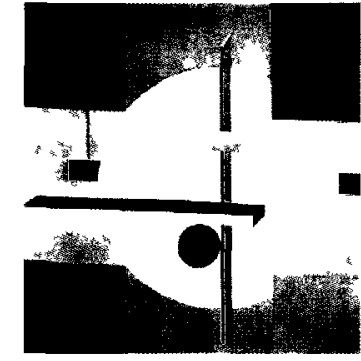
The axonometric, however, extends the vanishing point to infinity where, as Stan Allen explains: "The infinite extension in depth coincides with the suspension of the subject's privileges of self-location. The viewing subject and the object of representation both inhabit the same extended field. Projection operates to simultaneously extend and collapse distance." ${ }^{3}$ Axonometric projection contained an ability to remain measurable and precise while, at the same time, capable of transmitting abstract ideologies. Lissitzky's attraction, the axonometric, was a 
vehicle capable of conveying the potential constructability of his utopian visıon. ${ }^{4}$ Milka Bliznakov reinforces this in The Rationalist Movement in Soviet Architecture in the 1920's, arguing that Lissitzky's Prouns achieved a new system of spatial representation that responded to the architectural realm's inevitable need for materiality, applicability and stability; ${ }^{5}$ a response befitting the promotion of utopian Suprematist visioning.

The axonometric cannot only represent infinite space, but also new concepts of time. Allen explains how, "If perspective, dependent on a fixed point of view, seemed to freeze time and motion, the atypical space of axonometric suggested a continuous space in which elements are in constant motion." ${ }^{6} \mathrm{Re}-$ sulting in the simultaneous presentation of an object in multiple views that, from a distance, the observer holds the ability to freely rotate, dismantle and reconstruct.' Speaking of the experience of Lissitzky's Prouns, Albert C. Smith explains in Architectural Model as Machine, how "The resulting image is not a painting but a structure around which we must circle, looking at it from all sides, peering down from above, investigating from below...We screw ourselves into the space...Proun does not serve any particular goal, as it has the power to create such goals (and, indeed, the power to create new materials by creating the new forms which demand them). It transcends both the engineer and the traditional artist, somehow superseding the individual producer of architecture through the introduction of the princıple of collective creativity." ${ }^{8}$ Alan C. Birnholz reinforces this notion in El Lissitzky and the Spectator: From Passivity to Participation, claiming the experience of movement provoked by the Prouns, "occurs wholly inside the spectator's mind," strengthening Lissitzky's proposal to reverse the role of the spectator from passive to active. ${ }^{9}$ This new active role can be related to that of the creative imaginative role of the spectator as well as the architect which, Robin Evans asserts in Architectural Projection is a prerequisite for achiev-
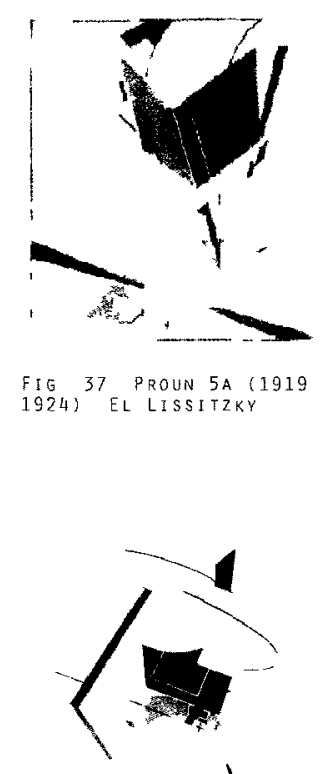

$\backslash$
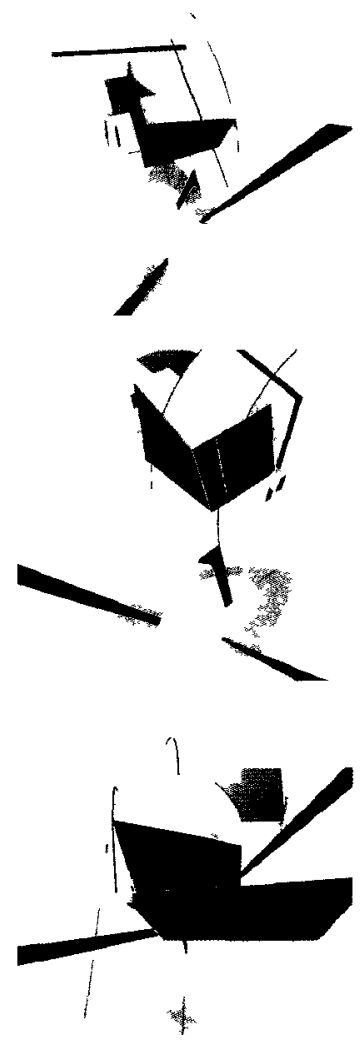

FIG 38 SCREWING INTO PROUN 5A (DIGITAL RE MAKE) LAVA 
ing architectural representation. ${ }^{10}$ Evans suggests that architectural projections "relates pictures to things" to either "record or propagate things already made" or "to project things as yet unmade."11 According to Evans, axonometric projection was traditionally "the preponderant method for devising, picturing, and transmitting ideas of buildings before they are built." ${ }^{12}$ Lissitzky's Prouns, were the first attempts to utilize the axonometric beyond the representation of the technical or practical, thus opening toward the aesthetic. ${ }^{13}$

For Lissitzky, Prouns were a departure from the "confinements dictated by the uncompromising strictures of Modernism ${ }^{114}$ and even more so, as an alternative interpretation of Constructivism and Suprematism. ${ }^{15}$ He spoke of Prouns as "an intermediary station on the road between painting and architecture."16 Thereby, referencing how through illusion, his Prouns necessitate a three-dimensional mental construction inviting the observer to fulfill the Prouns' form generating qualities. His Prouns, according to Evans, explored new potentials by emphasizing (notably a principle idea of Malevich) the participation of the human mind as a source of liberation from gravity; providing Lissitzky with the ability to introduce "a change of sensibility by exploiting a visual ambiguity that causes the viewer to lose his bearings." ${ }^{17}$ Evans infers that the ability of the axonometric to convey the Suprematist sense of weightlessness to the viewer was achieved by contrasting the familiarity of perspectives in which the fixed vantage point allows viewers to know their place. ${ }^{18}$ The Prouns proposed architectural ideas such as a building, bridge or city but without any of the technical representations necessary to realize their constructability, presenting alternative realities that destabilized a spectators spatial assumptions with no given solution to regain balance..$^{19}$ For example, Proun 1-E (1919-20) presents a spatial arrangement in bird's eye view, thereby suggesting the architectural form and idea of a Suprematist-town or town square. Lissitzky's uses of colour convey qualities of
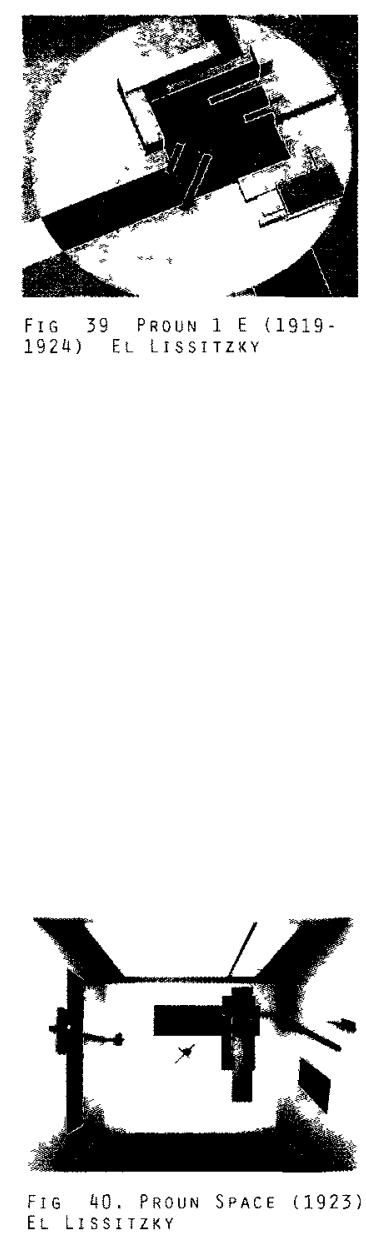
EL LISSITZKY 
materiality to our perceptions and thus reinforce the ability of Prouns to be perceived or approximated as actual buildings.

The Proun, however, could not move beyond its task as a representation device, only capable of suggesting something beyond itself as opposed to having the capability to generate them. According to Allen, the 1923 Proun Space confirms this because, "the infinite extension of the visual field is more present as representation than as experience. ${ }^{\prime 20}$ And with this, Lissitzky would have realized the difficulty in transferring the intentions of his imaginary Proun spaces into tangible architectural propositions.

\footnotetext{
1 MOMA The Collection 2010 http / /www moma org/collection/object php?object_td=79040 (accessed November 21, 2010)

2 Allen, Stan "Practice Architecture, Technıque + Representation" 22, Routledge, 2009 (New York)

3 ibid, Allen p 16

4 ıbid

5 Milka Bliznakov, "The Rationalist Movement in Soviet Architecture in the 1920's," pp 150-151

6 ibıd, Allen p 19

7 ibıd

8 Smith, Albert C Architectural Model as Machine p 105

9 Birnholz, Alan C "El Lissitzky and the Spectator From Passivity to Participation,"pp 98-101

10 Evans, Robin "Architectural Projection" p 19

11 ibid

12 ıbid, Evans p 21

13 ibid

14 Lodder, Christna Russian Constructivism pp 180-188

15 Bowlt, "Manipulating Metaphors El Lissitzky and the Crafted Hand," pp 133-148

16 El Lissitzky cited in Sophie Lissitzky-Kuppers, El Lissitzky, London, 1980, p 325

17 Robm Evans, The Projective Cast, Architecture and Its Three Geometries, p 339

18 ibld , Evans p 339

19 ibıd , Birnholz, pp 98-101

$20 \mathrm{~b}$ id, Allen $\mathrm{p} 22$
} 


\subsection{STRUCTURAL CONSTELLATIONS}

"I prefer to show some straight lines, unmodulated and two-dimensional, which through their constellations challenge our reading of them, and with this, our imagination. As we regard these, their directions constantly change. We perform perceptual effects by adding and seeing spatial qualities and motion, both of which do not exist factually, but only in our producing and seeing them." -Josef Albers ${ }^{1}$

Lissitzky Prouns (much like Speculations) deploy a subjective ambiguity similar to the various kinds of perceptual confusion that can be evoked by geometric illusions. ${ }^{2}$ Spatial ambiguities occur when a drawing lacks enough contextual signs to sufficiently define objects; prominent in the axonometric nature of Lissitzky's Prouns. According to Yves-Alain Bois in El Lissitzky: Radical Reversibility "The pretension/retention or plus/minus effect of axonometry is intensified in almost all of the Prouns." ${ }^{3}$ Further, according to Linda D. Henderson in The Fourth Dimension and Non-Euclidean Geometry in Modern Art, the "often, impossible overlapping and intersections, as well as the tendency of forms to fluctuate back and forth, suggest that only a higher dimensional space could encompass such contradictions." ${ }^{\prime 4}$ These are characteristics which Lissitzky exploited in his Prouns as abstract models of freedom. A strategy to resist dogmatic ideological and theoretical artistic conventions through the use of perceptive illusions. ${ }^{5}$

Similarly, Bois connects Lissitzky's Prouns to Joseph Albers' Structural Constellations which "are the mechanical exploitations of this seesaw property inherent in axonometry." ${ }^{\prime \prime}$ Albers' Structural Constellations immediately captivate the viewer, developed not so much with the intention to evoke a message but to ambush one's perceptual norms and expectations. Overlapping of lines (despite

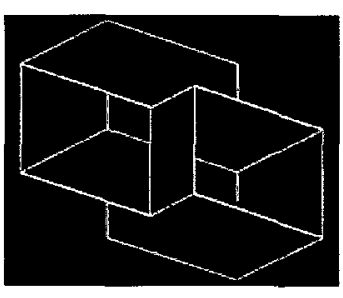

FIG. 43: STRUCTURAL CONSTEL LATION (1955), JOSEF ALBERS their relative flatness) suggest three-dimensional figures and relationships latent with contradictions and ambiguities. Just as Louis Albert Necker's observations of the 'Necker Cube', Albers' Structural Constellations are representations of 'ei- 
ther-or' and 'both-and' relationships.' Albers arranges the constellations of twodimensional straight lines in such a way as to challenge our reading of them; their directions constantly change, representing a motion of three dimensional spatial forms which factually, only exist in our imaginations. ${ }^{8}$ Albers uses geometry to arouse a kind of lure, where the idea of 'what you see is what you get' results

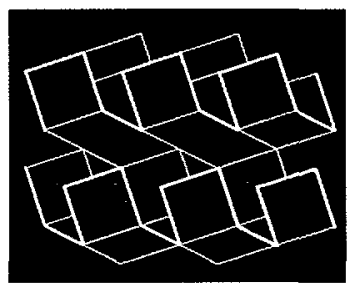
Fig 44 SiRUCTURAL CONSTEL LATION (1955) JOSEF ALEERS in more than one realizes. According to Albers, emphasizing the phenomena of seeing attempts to preserve an artistic authority, resulting in an autonomous or intentionless work through the removal of the author. ${ }^{9}$

1 Auerbach, Anthony W Structural Constellations Excurses on the drawings of Josef Albers c 1950-1960 p 213 2 ibid, Auerbach p 196

3 Yve Alain Bois 'El Lissitzky radical reversibility' in Art in America 76/4 (1988), p 172

4 Henderson D Linda The Fourth Dimension and Non Euclidean Geometry in Modern Art, p 294-95

5 ıbid, Bols p 175

6 ibid, Bois p 172

7 ibıd, Auerbach $p 206$

8 ibid, Auerbach o 213

9 ibid, Auerbach p 214 


\subsection{MICROMEGAS}

"It is not a matter of piling superimposed hierarchies one on top of another; rather, the trajectory of intentions transposes content into operation and at the same time displaces descriptive geometry by the structural. The transformation of object into operation imposes a temporal dimension on this process; a process whose meaning is not arbitrary and yet is not predetermined either." -Daniel Libeskind (Micromegas) ${ }^{1}$

Historically, the axonometric has origins dating back to ancient Greece and has developed alongside the emergence of perspectival projection. ${ }^{2}$ Whenever questions of measurability or verifiability in drawings arise, so does the axonometric. Not surprising then is that the earliest standardizations of axonometric techniques originated as a military tool to chart three-dimensional trajectories of artillery projectiles: Later, this developed in engineering schools during the eighteenth and nineteenth centuries as a measurable representational tool for the construction of mechanical and industrial parts. The advantage of an axonometric was its ability to provide the visual immediacy of the perspective with a measurable consistency that easily transmits to a corresponding plan, section and/or elevation view. ${ }^{3}$ It was not until the early Twentieth Century, however, when the axonometric was used by Russian avant-garde artists as more than just a scientific representational tool. Artists such as El Lissitzky utilized the axonometric as a vehicle to visually promote the ideologies and utopian visions of social reform. ${ }^{4}$ This reinterpretation of the axonometric as a vehicle for universal, abstract thinking however, according to Stan Allen, was never fully integrated into architectural practice until the projections of Daniel Libeskind, "where an investigation of the means of representation takes precedence over a realized building...architects have fully exploited the implied reversibility of depth and foreground that characterizes axonometric projection. ${ }^{\prime 5}$

Daniel Libeskind's Micromegas are of particular interest due to their axonometric characteristics and stunning similarity in conceptual intentions (without any prior knowledge) to that of Speculations. Libeskind's explanation of his intentions is, in fact, the very source of definition and understanding needed to grasp the capabilities of Speculations.

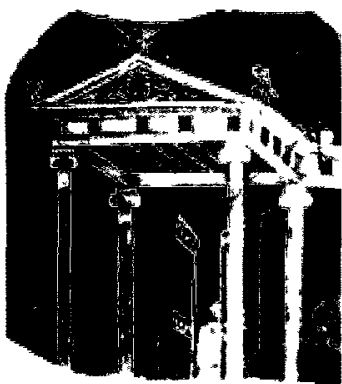

FIG 45: VASE FRAGMENT (IV C. BC). Magna GRECTAE TARANTO
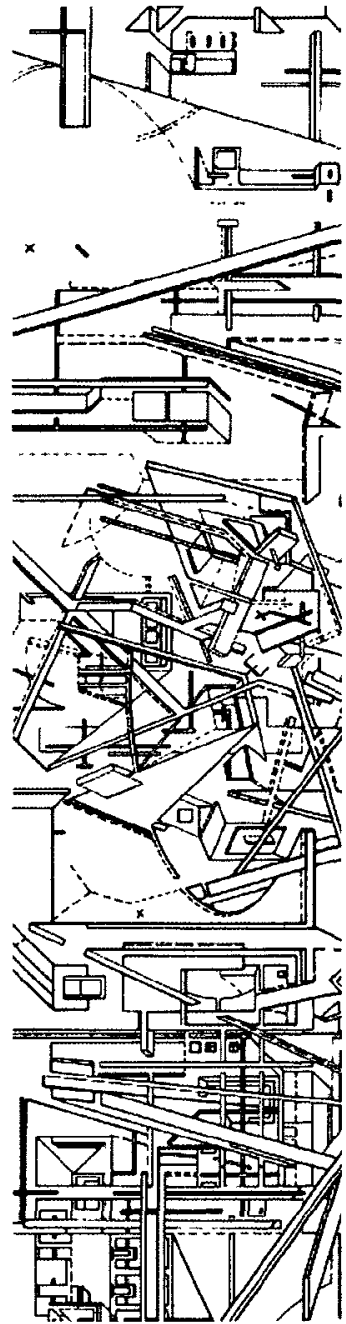

FIG, 46: MICROMEGA: ARCTIC FLOWER (CROPPED) (1979),

DANIEL LIBESKIND 
In The Space of Encounter, Libeskind's describes Micromegas as "attempts to express this inadequacy at the heart of perception for which no (final) terms are provided; a lack of fulfillment which prevents manifestation being reducible to an object-datum...there is a presentation, but always according to the mode of imperfection...these drawing and collages develop in an area of architectural thinking which is neither a physics nor a poetics of space" ${ }^{\prime 6}$ This 'area' of architectural thinking is comparable to the 'between space' discussed previously, where the experimentation of existing architectural methodologies guide us toward new discoveries that, in turn, give rise to new questions to explore. Although many forms appear to the observer in Micromegas, they remain incomplete or unattainable to recognition, thereby forcing one to re-evaluate their "[overlapping] concepts and premonitions.." As authentic abstractions, Micromegas "gives us what is most unique in incomplete but formalized levels of grasping objects...uniqueness is given in an impure fashion, blended as it is with elements representing categories of experience which must be progressively extracted from the general alienation of over-qualified intuition of spatial structure...through a series of successive steps, to realize the elimination of intuitive content and numerical relations, and leads to ever more encompassing (spherical) possibilities of configuration." ${ }^{8}$ It is our task then, to continue the questions they expose.

Developing Speculations was not simply a process of randomly drawing incomplete and overlapping forms with no apparent hierarchy but, rather, an operation to transpose a conceptual intention with the use of known axonometric techniques and tools. Similar to Micromegas, they characterize the transformation of an object into operation, imposing a process whose meaning cannot be pre-determined and yet, not arbitrary either. ${ }^{9}$

\footnotetext{
Libeskınd, Daniel The Space of Encounter Universe, 2000 p 87

2 Scoları, Massımo "Elements for a History of Axonometry" Archıtectural Desıgn Profile 59 The School of Venice, 1985 p 73

3 Allen, Stan "Practice Architecture, Technique + Representanon" 18, Routledge, 2009 (New York)

4 ibid, Allen p 24

5 ibid

6 Ibıd, Libeskınd p 87

7 ibid

8 bid

9 ibid
}

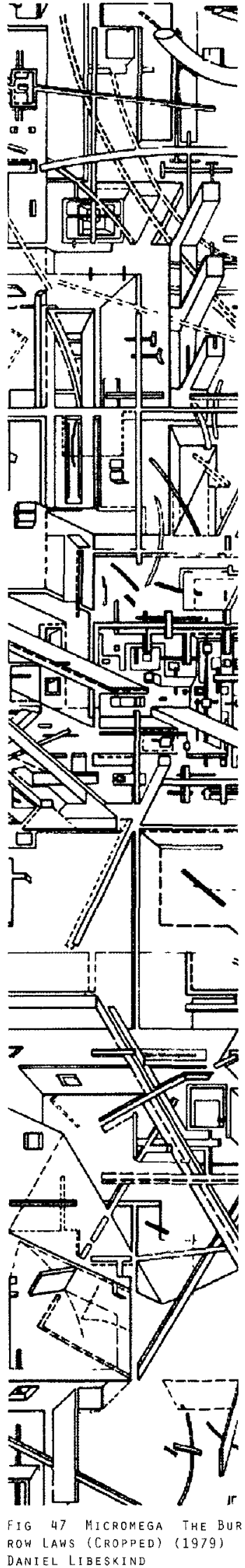




\section{CHAPTER 3:}

\section{FROM ILLUSIONS TO ALLUSIONS}

\subsection{DRAWING GAZE}

"When the architect is exposed to chaos there is a stirring up of the unconscious psyche, which produces fantasies, hallucinations, and visions. However, for all its horror and confusion, the experience of chaos is seen by architects as a positive experience, since it allows relationships to be seen in new and unusual ways." -Joy Monice Malnar and Frank Vodvarka ${ }^{1}$

Similar to Daniel Libeskind's Micromegas, Speculations fascinate and perplex the participant into a desire to fulfill their original pre-comprehensions of geometric forms. The participant is entrapped in a visual labyrinth where one's grasp of single or multiple forms inevitably reconfigures the pre-established grasp of others. ${ }^{2}$ Daniel Libeskind states how such drawings, "seek to reflect, on a deeper level of consciousness, the inner life of geometrical order whose nucleus is the conflict between the voluntary and the involuntary." ${ }^{3}$ Such conflicts force the participant to re-evaluate their pre-conceived or a priori understandings of geometrical relationships. Antony Flew clarifies this in A Dictionary of Philosophy: "An a priori proposition is one which can be known to be true or false without reference to experience, except in so far as experience is necessary for understanding its terms." ${ }^{4}$ Of course, the participant is only capable of experiencing as much as he or she is willing to give. That is, the drawings are defined by the limitations of the participant's perceptual and imaginative interactions. ${ }^{5}$ Sanford Kwinter in The Hammer and the Song, refers to Imannuel Kant's definition of this notion of experiencing the world as 'the formal domain,' where "that which we are interested in when we want to understand the diagram [drawing], belongs on the side of the perceiving mind or agent; it refers to an a priori organization. ${ }^{\prime 6}$ Often, Architect's clients struggle to visualize architectural diagrams such as plans, sections, elevations and axonometrics because they are unfamiliar or untrained to perceive how particular symbols and notations portray architectural arrangements. The reading of architectural representations relies heavily in this

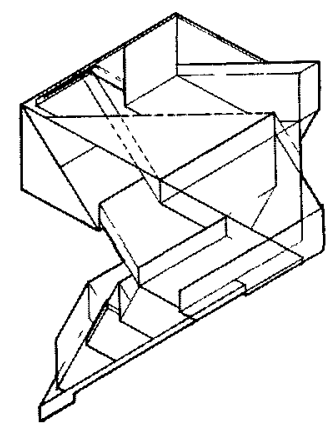

FIG 48: SPECULATION VIII (2010), JARED HAGENS

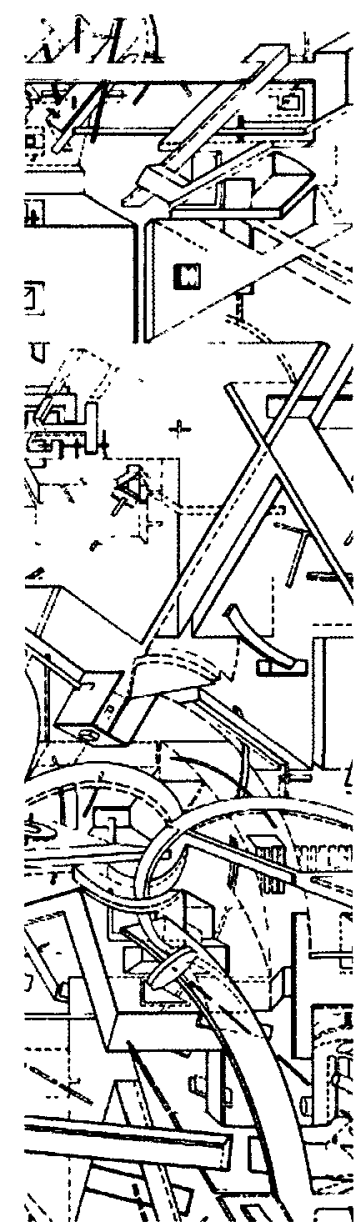

FIG 49 MICROMEGA, VERTI CAL HORIZONS (CROPPED)

(1979), DANIEL LIBESKIND 
'formal domain' where, as Robin Evans explains in Architectural Projection, the observer's imagination is crucial for the "mobilization of the projected information" or "projection" of potential future architectural objects.

Removing the 'activating imagination' of a participant establishes architectural projection as a mere 'technical facilitator' which leads him to realize that "drawings can propagate things but never generate them." ${ }^{8}$ This is an important point because it confirms how Speculations as drawings alone, unobserved, are FIG, 50: DRAWING GAZE. WWW. FLICKR, COM not capable of generating new forms. They can only propagate architecture and are reliant on the participant to fulfill its ability to generate architecture. As a tool for generating design, Speculations evoke a certain chaos, stirring up the unconscious psyche, freeing the architect's imagination from the constraints of habitual, repetitive designs of accepted practices. ${ }^{9}$ A means for the architect to conjure or discover spatial potentials that he or she could not otherwise have realized without influence can still be argued that the drawings are simply a tool that requires the participation of a knowledgeable user to fulfill their intentional uses.

Nader El-Bizri speaks of the imagination as a, "faculty" that "furnishes" one's a priori, allowing knowledge of phenomenal works to render as possible through "synthesizing the manifold of [one's] sensory impressions into the form of a unified image." Imagination allows for new understandings to formulate through recollecting or associating appearances with familiar accepted representations. ${ }^{10}$ Thus recalling Evans, who sees the imagination essential for the success of architectural representations as, "the observer's imagination is itself comparable to [the] projection" envisioned by the architect. ${ }^{11}$

\footnotetext{
1. Malnar, Joy Monice; Vodvarka, Frank. "Diagrams in Multisensory and Phenomenologıcal Architecture." Op.cit., The Diagrams of Architecture. ed. Garcia, Mark. p.114

2. Libeskind, Daniel. The Space of Encounter. Universe, 2000. p. 87

3. Ibid. Libeskınd. p.87

4. Flew, Antony. A Dictionary of Philosophy. Gramercy; 2 Sub edition (September 14, 1999)

5. Ibid. Lıbeskınd. p.87

6. Kwinter, Sanford. "The Hammer and the Song," Op.clt., Diagrams of Architecture. ed. Garcia, Mark. p.123

7. Evans, Robin. "Architectural Projection." p.21

8. Ibid. Evans. 0.21

9. ibid.,Malnar, Joy Monice; Vodvarka, Frank. p.114

10. El-Bizri, Nader. "Imagination and Architectural Representations." Op.cit., From Models to Drawings, p. 40

11. Ibid. Evans. p. 20
}

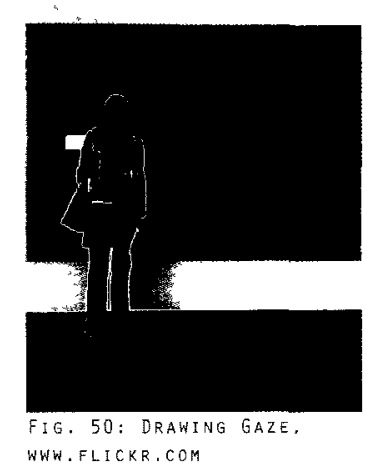




\subsection{ILLUSIONS + PERCEPTION}

"Thus our perceptual systems are influences by both prior experience as manifested in memory, and preference factors as they affect the perception of the contents of our milieu." -Joy Monice Malnar and Frank Vodvarka ${ }^{1}$

If one plays with illusion, does its falsehood become apparent? With Speculations, the spatial potentials are understood as impossibilities that necessitate another mode of representation. What step takes the spatial falsehoods to a higher degree of coherence without hindering the design process? How do Speculations act as a vehicle to generate further design? Here, a system for interpretation acts to translate the illusions of architecture to allusions of architecture, where proportions and scale of one unknown is confirmed in relation to another. This act of translation is a source for invention where the imaginative interpretations of the illusions materialize as reality. It is how to understand and generate concepts where associated rules or criteria can direct the design development process. Of course, Speculations has the ability to deceive viewers by presenting a false impression of reality from a fixed position. Unlimited vantage points however can be provided by utilizing the architectural scale model as a means to eliminate speculation and permit the confirmation of the viewer's per-
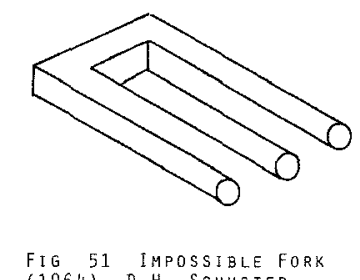
(1964) D H SCHUSTER ceptions.

A.C. Smith confirms how, 'as a next step', the architectural scale model methodology contains the necessary characteristics for translating the illusionistic qualities of Speculations into tangible allusions of architectural spaces: "When architects manipulate their scale model mechanisms they play with their imaginations. They can use the scale model to discover the unknown. Allusions and analogies appear to architects through the mental projection of thoughts on to the framework offered by the machine-like scale models. It is through scale models that architects can develop the allusions and analogies used to participate in a broader search for true definition."

Here we work with, if not depend on, the perceptions of the observer to achieve a definition(s) that can be taken forward or developed as spatial exercises of architecture. Perception is a process of interpretation and organization of sensations as a means to understand our experiences. Sensations are the immediate and unprocessed stimulations of the body's sensory receptors which

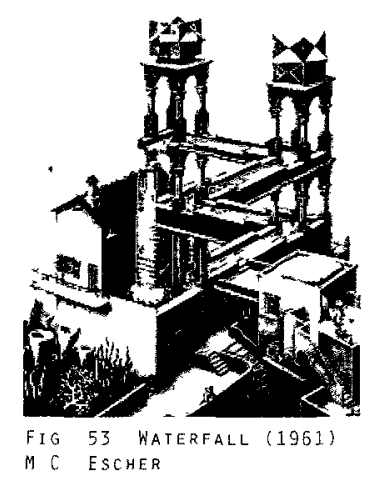


perception processes into one's experience or understanding of the world. This processing of raw sensory stimulation involves a set of mental activities that include thinking, knowing, and remembering. Past experience, or the knowledge acquired through past experience, is critical in making sense of our sensations and perceptions. ${ }^{3}$

Can it not then be argued that perceptions are unique to each observer because of a reliance on prior experience which varies according to cultural, ethnic, social and personal patterns. ${ }^{4}$ Joy Monice Malnar and Frank Vodvarka confirm this: "the perceptions of two individuals vary as a function of differences in the content of the information presented and the differences in the ability of individuals to pick up the information messages." ${ }^{5}$

Despite the many variants that affect individual perception, there still remains a general stability or 'constancy' in our perceptions. Perceptual 'constancies' match perceived objects showing why we can familiarize objects as having standard characteristics such as size and shape, regardless of their distance, lighting or angle of perspective. Perceptual constancy allows us to take into account the various conditions that potentially skew our senses in order to identify objects according to a known image. ${ }^{6}$ For example, if there are adequate visual cues available to validly asses one's distance from an object, the understood size of that object will remain stable. One's perceptions adapt to sensory stimuli and this adaptation forms a bases from which any new stimuli are perceived.

Again, the illusionary characteristics of the drawings act to intentionally challenge our perceptual constancies in an effort to provoke the imagination to formulate new spatial relationships. Similar to the 'figure and ground' illusion, the perceived relationship of a figures fluctuate so that seeing one form apparently excludes seeing the other. This often occurs even without conscious effort to shift attention. ${ }^{7}$

1 Malnar, Joy Monice, Vodvarka, Frank "Dlagrams in Multisensory and Phenomenologıcal Archıtecture" Op cit, Diagrams of Archı tecture ed Garcı, Mark p 114

2 Smith, Albert $C$ Architectural Model as Machine p 47

3 Winkler, Ramona Optical Illusions Ed Gerd Waloszek Aprıl 2006 November 2011 <http //www sapdesignguld org/resources/ optical_Illusions/optical_lllusions pdf>

4 ibıd, Mainar, Joy Monice, Vodvarka, Frank p 114

5 ibıd Malnar, Vodvarka p 117

6 ibid Winkler

7 bbid Winkler

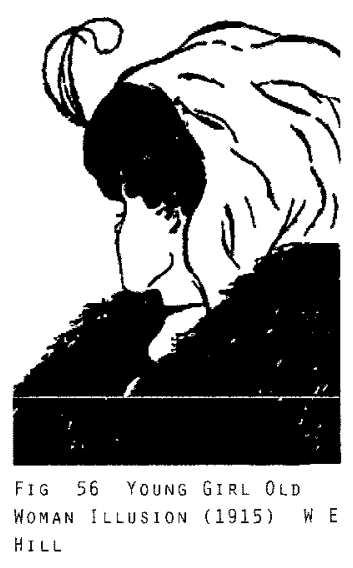




\subsection{MOdEL TRANSLATIONS}

"To be useful for architects, the free association reflected from the scale model machine needs to be governed. This governing comes from the relationship of the architect with his or her reference standard. If the reference standard governs too loosely, the message received from the scale model machine will appear uncanny or overly spontaneous. If the reference standard governs too much then the message reflected from the scale model machine will be lifeless."-Albert C. Smith ${ }^{1}$

Rules or criteria are needed to narrow the unlimited potential trajectories of any process, otherwise it can become infinite, chaotic and/or arbitrary. ${ }^{2}$ Design guides are necessary for developing a definition in order to coherently understand the messages conveyed throughout the process. Over governing the process, however, risks restricting the freedom of design that can lead to new unforeseen discoveries.

The physical model explorations of Speculations were attempts to clarify and develop potential spaces found within the drawings; a mechanism to achieve definition and mediate between the perceived chaos found in the drawings and architectural design. ${ }^{3}$ The models represent and document these explorations in chronological order, and exemplify the necessity to control the unlimited potentials of the design process. The models become subjective interpretations and conceivable translations of the impossible spaces found within drawings. According to A.C. Smith, "The architectural scale model helps the architect to create allusion and can be used to destroy illusion." ${ }^{4}$ The drawings deceive the viewer by portraying false impressions of reality and, as they are only viewed from one position, models become necessary to complete the invisible unknowns (in) behind the drawing's opacities. Each attempt to re-translate a drawing with changes in construction materiality as well as imagination, perception and construction methodology (resulting from knowledge acquired through previous processes and experimentations) result in uniquely different interpretations. This leads to the belief that within the interiority or the drawings and models, are traces of the

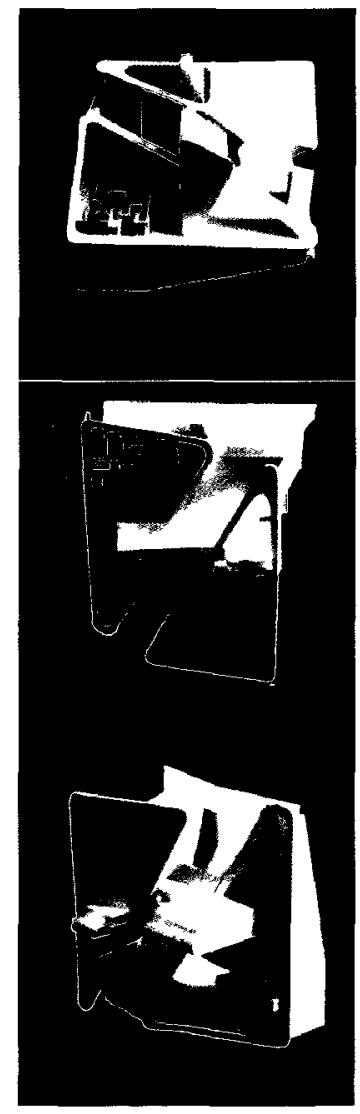

Fig 57 SPECULATION VI \& MODELS (2010) JARED HAGENS unlimited architectural potentials, alluded to through construction, materiality, proportions, patterns, etc. 
The architectural model in this case is a scale device that provides a means for architects to achieve the understanding, definition and measure of various unknowns. ${ }^{5}$ Models compel the architect to foresee the future building and potential problems which may occur. Due to the absence of scale caused be the illusions of the drawings, it was necessary to develop a proportion system to optimize their development as scale model allusions. Recognizing the proportions of geometries as fractions (full, double, half, quarter etc.) to one another, allowed the production of measureable (for example $1 \mathrm{~cm}, 2 \mathrm{~cm}, .5 \mathrm{~cm}, .25 \mathrm{~cm}$ etc.) material cuts to construct the perceived geometries. Thus, allowing to physically and irreversibly, determine the positioning of an illusionary form relative to all others. These determinations are translations of the drawing because they eliminate the geometrical illusions piece by piece and form, to the best of one's ability, a physical representation of their imaginative spatial interpretations. Smith confirms this importance of scale: "Scale allows the architect a means for climbing towards a definition, developing a balance or medium between a known and an unknown, creating a standard with which to refer and a way of peeling away to reveal that which is unseen." ${ }^{6}$ However, the measurable system developed provides a mere sense of scale as opposed to a pre-determined scale. Resisting the over-emphasis on precision allowed the models to develop into coherent allusions that freely continue the design process by projecting one's thoughts onto the scale model to make it appear (in the realm of our imagination) to take on a life of its own. ${ }^{7}$ Here the imagination mediates, according to Smith, "between ideas of memory and judgment" and the architectural model machine dwells in this realm in order to develop the free associations needed to conjure new ideas. $^{8}$

\footnotetext{
1 Smith, Albert C Architectural Model as Machine p 123

2 bid $p 123$

3 lbıd $\mathrm{p} X \mathrm{~V}$ ।

4 ibid $p 47$

5 ibid $p x X I$

6 Ibid oXVIII

7 ibıd $p X X \mid$

8 ibid
}

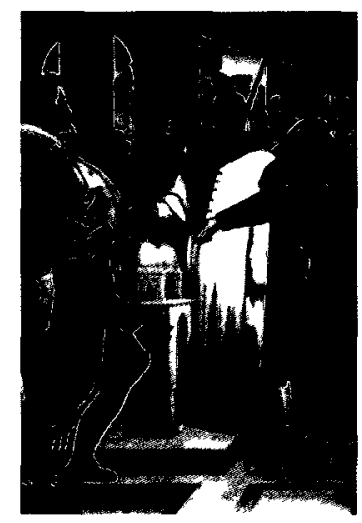

Fig 58 Michelangelo Pre Senting Model to the pope CAsa FIRENZE BUINARROT 1

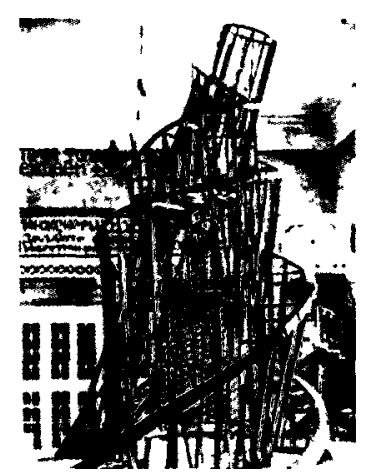

FIG 59 TATLIN S TOWER MONUMENT TO THE THIRD IN TERNATIONAL (1917) VLADIMIR TATLIN

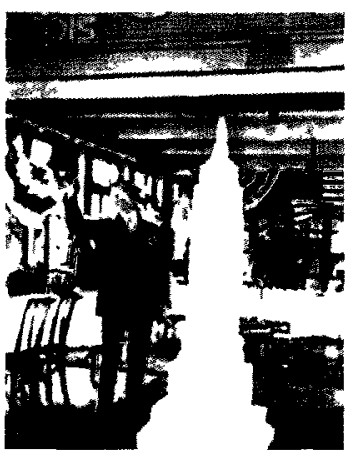

Fig 60 empire state build ING MODEL BETTMANN 


\section{I A G RA : \\ FROM ILLUSIONS TO ALLUSIONS}

The following matrix is an example of some of the models produced to translate the impossibilities (within Speculations) into possibilities. Models were constructed as closely as possible according to the visual cues provided in each Speculation drawing and then documented at various stages in order to demonstrate in physical form, other potential imaginative spatial variations interior to each drawing. These models are a necessary step to continue towards the realization of innovative architectural prototypes. The models, 3-dimensional representations, allow one to maneouver in and around the Speculation in order to develop greater association and discover new relationships.
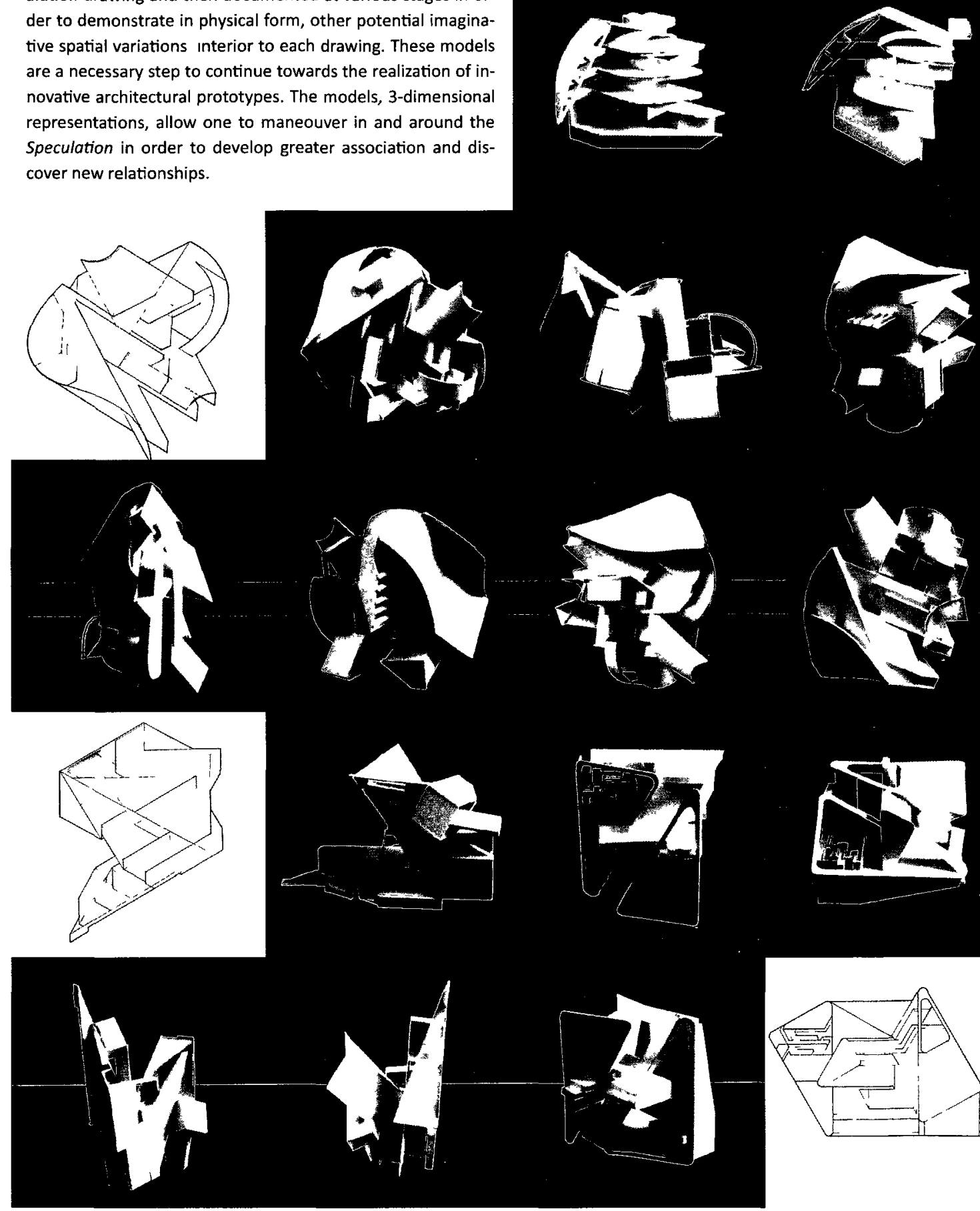

th

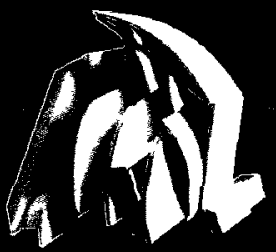

\section{西}




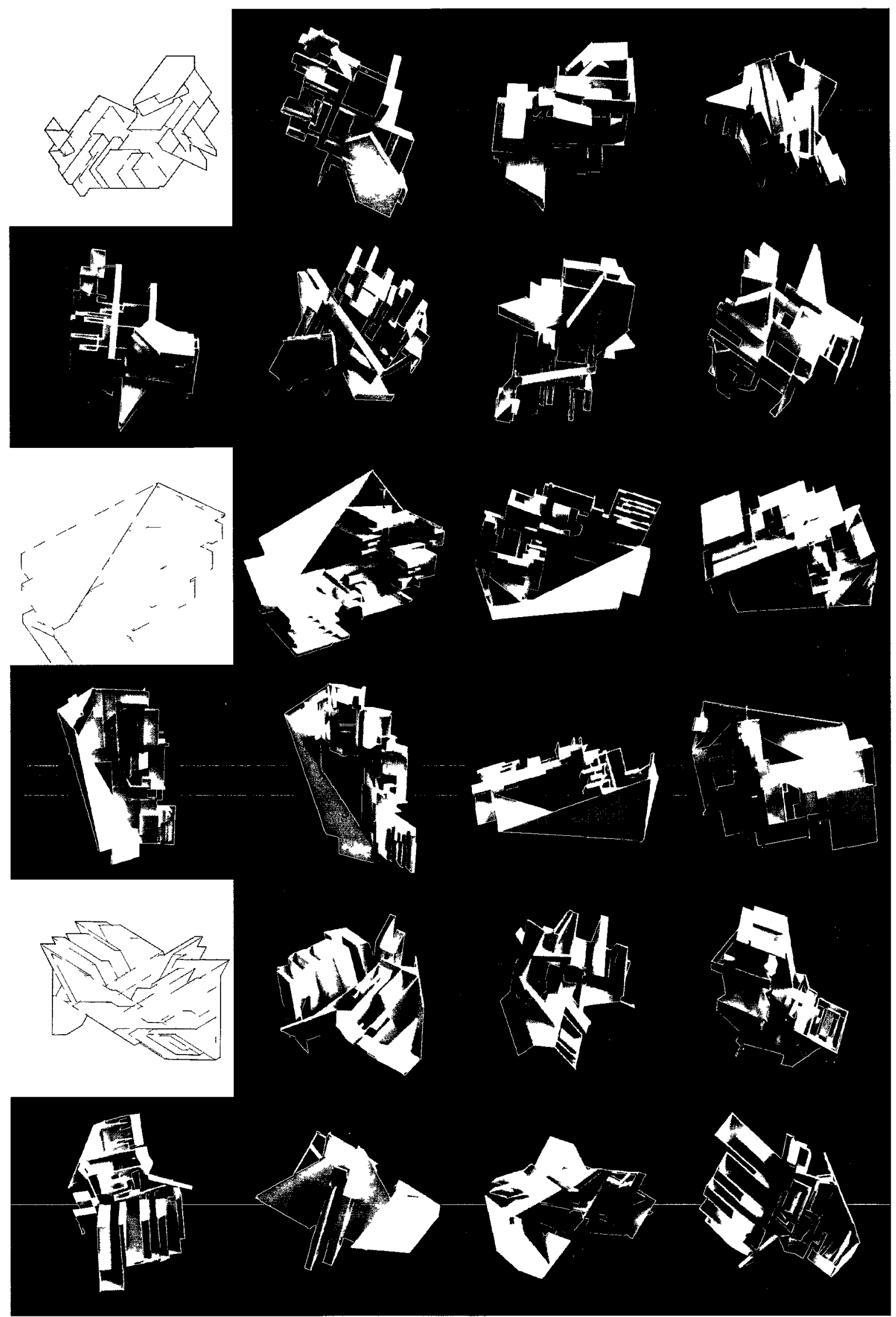




\title{
CHAPTER 4 :
}

\author{
DIAGRAMS: TRACES OF PETER EISENMAN
}

"Since the mid-20th century, the diagram has taken first place among the techniques and procedures of architectural knowledge, usurping the place of the drawing... the diagram has gained amazing prominence as a leading term in theoretical discourse." -Gerrit Confurius ${ }^{1}$

What is a diagram? Known in Latin as diagramma; it means variously that which is marked, figured, traced, symbolized, written or drawn out. Coming

FIG. 61: UNITE D'HABITATION DIAGRAM (1945), LE COREUSIER from the Greek term Dia- meaning 'across, out or between-two' and gramma meaning 'figure, mark or line that is made'. ${ }^{2}$ There are many different definitions and/or understandings but Mark Garcia defines a diagram in The Diagrams of Architecture as "the spatialisation of a selective abstraction and/or reduction of a concept or phenomenon. In other words, a diagram is the architecture of an idea or entity ${ }^{\prime \prime 3}$ However, among the design disciplines there is little consensus as to how to distinguish the diagram from the drawing, sketch, model, map, process, concept and/or even photograph, resulting in a diluted understanding that runs the risk of collapsing into even more general concepts of form, space, structure, process, pattern etc. Ben van Berkel and Caroline Bos reinforce this in Diagrams, simply stating (with particular importance to this inquiry) how, "an image is a diagram when it is stronger than its interpretations." ${ }^{\prime 4}$ So too then can it be inferred, as Hyungmin Pai argues in Scientific Management and the Birth of the Functional Diagram, "that plans, sections and elevations [and as previously mentioned, models], those traditional modes of architectural representation, are themselves diagrams. ${ }^{5}$ In this regard we have understood Speculations as diagrams; they generate as many interpretations, associations and definitions as there are observers willing to participate; they allow ideas to generate and/or be transmitted into other speculative forms. Historically, diagrams were understood as either an explanatory analytical device, or a generative device. In the design process, a generative diagram is also a form of representation but one that differs from

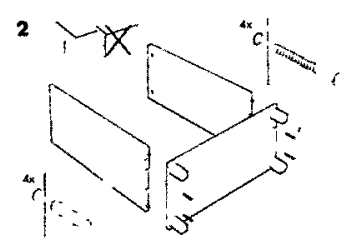

Fig. 62. CABINET BUILDING INSTRUCTIOHS DIAGRAM IKEA

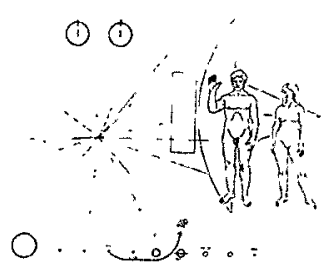

FIG. 63: DIAGRAM FOR EXRA TERRESTRLALS (1972), CARL SAGAN 
traditional forms of representation. According to Peter Eisenman in Diagram: An Original Scene of Writing, the diagram as a generator "is a mediation between a palpable object, a real building, and what can be called architecture's interiority." ${ }^{\prime 6}$ It inaugurates a cosmopoietic sensation, allowing for the imaginative emergence of other possible worlds. Speculations, as generative diagrams, are valued for their capacity to initially trigger such possibilities; possibilities which can only ever be partially realized and therefore maintain a continual applicability for developing a process ad infinitum. ${ }^{7}$ In such a process, closure or discontinuation can only ever be determined by external factors. Project requirements, propositions, aims and strategies are just a few of many externalities needed to develop the form of the diagram to the final form of a building. ${ }^{8}$

To explain the phenomena of being both content and expression, Berkel and Bos refer to Gilles Deleuze's classification of diagrams as abstract machines from A Thousand Plateaus: Capitalism and Schizophrenia. ${ }^{9}$ The diagrammatic or abstract machine "does not represent an existing object or situation, but is instrumental in the production of new ones." ${ }^{10}$ These are abstract because their conceptualizations are distinct form material reality. They are summaries and/or fragments of relationships and understandings. And they are machines because they assemble, organize and deploy this content. ${ }^{11}$ To inquire further into the theoretical development and applications of diagrams in architectural practice, it is important to situate the initial and influential diagrammatic studies of Peter Eisenman.

The architecture of Peter Eisenman is not simply summarized and/or defined as a cohesive "whole". His architectural theories and practice have undergone many theoretical shifts and changes. Though his early house studies (Houses I-X from 1967-82) are of a slightly different theoretical context, they are the foundation for his interest and theoretical development of an architecture
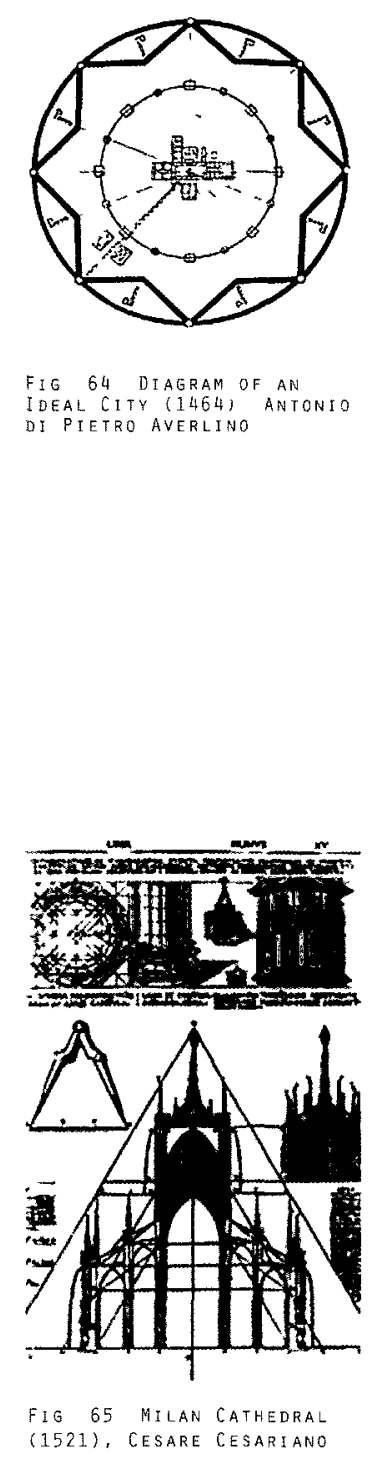

FIG 64 DIAGRAM OF AN FIG 64 DIAGRAM OF AN
IDEALCITY (1464) ANTONIO di Pietro AVERLINo

\section{.}


that has earlier been referred to as Deconstructivism.

Eisenman's house studies, in particular the earlier houses (House I-IV) were based on the notion of an architecture capable of revealing the power or methods of development within its own configuration. Eisenman believed in the ability to produce an environment that can accept or provide richer and more precise understandings of the structure of form in and of itself, as opposed to direct relationship to function and/or meaning. House / for example, posits an alternative to standard conceptions of spatial organization in an effort to discover operational or organizational systems capable of portraying and controlling the inherent logic within the relationships between forms and their corresponding function and/or meaning. ${ }^{12}$ Eisenman's early house studies in general, were attempts to separate form from function but, in an interview with Hans van Dijk, he contradicted and confused his true intentions when stating "without function there is no architecture." ${ }^{13}$ Though Eisenman's contradictions make it difficult to decipher a concrete theoretical context, it becomes apparent that his house studies are exactly that: studies which inquire into new potential understandings that may or may not always be clear and precise, undergoing a process which evolves with each new discovery or idea. This is apparent with House VI, for example, where Eisenman takes note of, and emphasizes the value of, process vs. outcome in the production of architecture.

For this inquiry, House $\mathrm{V} I$ is significant for several reasons. First, it recognizes the importance of process and thus provides necessary theoretical guidance and framework for conducting our inquiry, and further developing explorations into an architectural project. From this we learn to resist the compulsion to force the work to fit within a theoretical or conceptual context but allow the process to unravel and steer potential contexts. Secondly, Eisenman juxtaposes solids and voids to intentionally warp, distort and fluctuate the inhabitants spatial perceptions in an effort to critique conventional spatial understandings of architecture. ${ }^{14}$ These intentions echo with Speculations in their challenge of perceptual norms. And, much like House VI, these create formal arrangements that

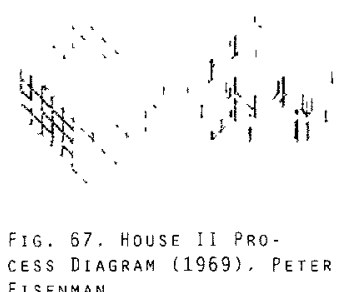

EISENMAN

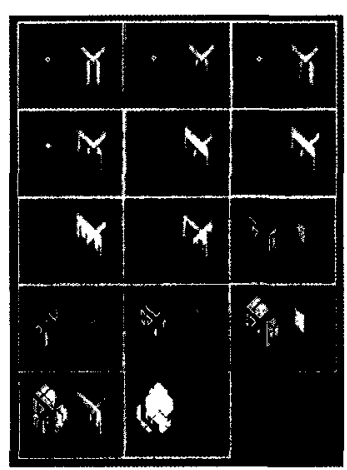

FIG 68. HOUSE VI PRO. CESS DIAGRAM (1975), PETER EISENMAN

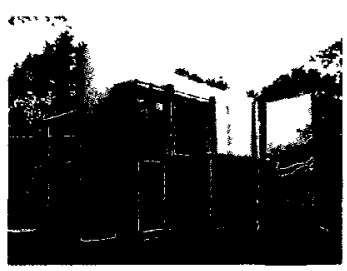

FIG 69. HOUSE VI EXTERIOR (1994), Peter EisenMan 
provoke a need to mentally re-order spatial elements and/or imagine alternative architectural potentials from within what physically exists. Thirdly, much like how House VI is a constructed moment 'of' the design process, so too can we see this process within the model constructions of Speculations. The models represent a construction of just one of the many potential architectures found within and in turn, allude to potentally many more.

Peter Eisenman's House $V I$ is not so much the end result of a process as it is a record of a process. ${ }^{15}$ Eisenman's architecture is known to be 'process driven' where a series of design procedures under the control of the architect result in architectural form(s). These graphic procedures have an internal logic which take form, guide, influence, and provide meaning and organize the manifestation of future architectural forms ${ }^{16}$ For Eisenman, design is the carrying out of a series of graphic procedures and operations to inscribe meaning onto architectural works. In doing so, the architect imparts meaning to a building which can be viewed as a process where visual cues and hints are intended to lead the viewer to interpret and decode the architect's design intentions and processes. ${ }^{17}$

In Peter Eisenman's House VI: The Client's Response, Suzanne Frank describes House VI: "The house, like the set of diagrammed transformations on which its design is based, is a series of film stills compressed in time and space. Thus, the process itself becomes an object; but not an object as an aesthetic experience or as a series of iconic meanings. Rather, it becomes an exploration into the range of potential manipulations latent in the nature of architecture, unavailable to our consciousness because they are obscured by cultural preconceptions. ${ }^{18}$ Eisenman's intentions with House VI were to transcend traditional views of designıng, seeing and understanding our environment. He hoped to "alienate the viewer from norms, expectations, and habits...a wake-up call, a shocking view into new spatial possibılities."19 ${ }^{19}$ achieves this by juxtaposing solids and voids in such a manner as to provoke a mental need to re-arrange the position of these elements in order to regain a conventional sense of spatial coherence or standardization. ${ }^{20}$ Frank explains this phenomenon, regarding architecture as a

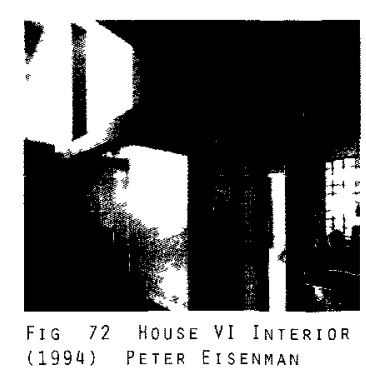


synthesis or transcendent state that arises out of a dialect between what is real and what is virtual; House VI (as a snapshot of design process) creates the necessary conditions to propose that dialect. ${ }^{21}$

Frank's coining of the term Dialect is interesting for us here because it can be referenced to Eisenman's later developed notions of deconstruction in architecture. Moneo mentions how, through later texts, Eisenman began to clarify the "often confused" architectural ideas about 'process' in his early works by referencing linguistics thinkers like Foucault, Deleuze and Derrida and providing “ideological proposals with real capacity to give content to his work... [ceasing] to be objective, abstract ideas, simple geometrical stimuli...that got a process of formal development going...now interpretations of historic evolution that could be materialized in a form." ${ }^{22}$ Though, for the purpose of this inquiry, Eisenman's theoretical influences will not be covered in depth, it remains important to note to situate Eisenman's transition from studies in form and process to his focus on the semiotics of the diagram. Here the diagram is essentially an expansion of the form development and process notions found in Eisenman's early house studies. And distinctive to Eisenman, is the use of the diagram in defining the design process. For Eisenman, the process of architectural development in fact forms a process, one in which he makes use of the architectural diagram to organize and elaborate theoretical developments. Eisenman's diagrams have since, for the most part of his career, been the foundation of his works and way of thinking.

One particular ideological influence (that Eisenman paralleled with architecture) is Jacques Derrida's notions of deconstruction in writing. Eisenman states "For Derrida, writing is initially a condition of repressed memory. The repression of writing is also the progression of that which threatens presence, and since architecture is the sine qua non of the metaphysics of presence, anything that threatens presence would be presumed to be repressed in architecture's interiority. In this sense architecture's anteriority and interiority can be seen as a sum of repressions. ${ }^{23} \mathrm{He}$ is inferring that there is already a form of representation interior and anterior to architecture which can be compared to or con-

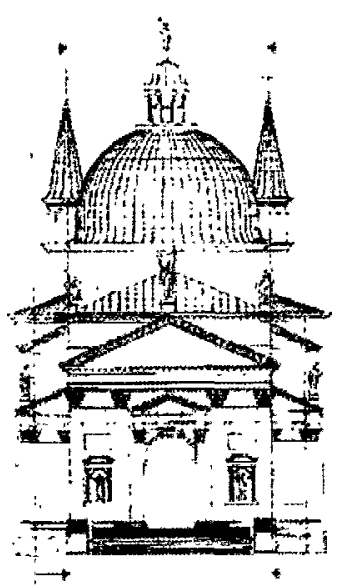

Fig. 73: ANALYTICAL DIAGRAM OF THE CHURCH OF THE REDEEMER: DIAGRAM OF ANTERIORITY (1982). PETER EISENMAN

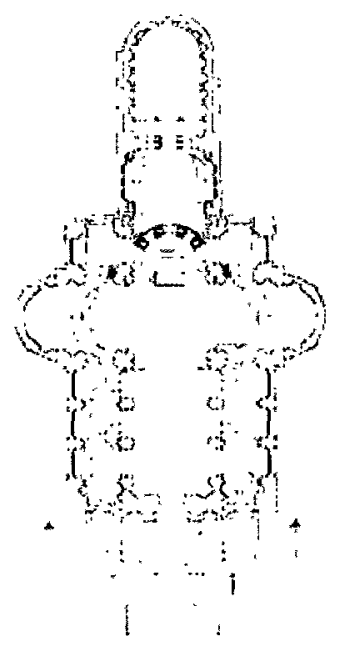

FIG. 74: ANALYTICAL DIAGRAM OF THE CHURCH OF THE RE DEEMER: DIAGRAM OF

ANTERIORITY (1982), PETER EISENMAN 
sidered as a form of writing. In this sense, architectural representations such as plans can be considered finite writings which contain interior traces of many other plans. Likewise, anterior traces are always present as they are a past summary of, and therefore are foundation to, all architectural representations. Mark Garcia explains this best for us when stating "For Eisenman, the diagram traces and writes, and can be traced and read in, architecture. As such, the diagram mediates between the history of architecture (diagrams of anteriority) and the ways in which this is traced in a real building and the other possible buildings that are within it (diagrams of interiority). Diagrams of exteriority, those from outside architecture, are defined as agents from the 'specific site, the program, or the history',"24

Eisenman's reform of the diagram, as explained in The Diagram and the becoming Unmotivated of the Sign, began to 'write' and 'rewrite' the metaphysics of presence in architecture, developing a design process that resists the susceptibility to influence or motive. He believed that architects (as designers) perform architectural sins by using externally motivated artificial signifiers to move architectural signs beyond their inherent internal motivations and structures. To Eisenman, the diagram acts as a resistant agent capable of overcoming the motivated sign in architecture; separating relationships between form, function and meaning by producing arbitrary connections to the signified. The diagram helps overcome the desire for a communicating signifier by blurring the relationship between the desiring subject, the designer and the desired object. ${ }^{25}$ According to Eisenman, "This removal and rupture allows a possible not-presence, a void within presence to be. This not-presence is a writing." ${ }^{26}$

Eisenman's notions have been widely accepted in the architectural theoretical discourse: In Imagination and Architectural Representations, Nader El-Bizri reinforces Eisenman's ideas, explaining how architectural drawings rerepresent the conventional standards of past representations which facilitate their generation. The repetition of similar pictorial architectural notations and symbols over time have formed the representational standards used in current

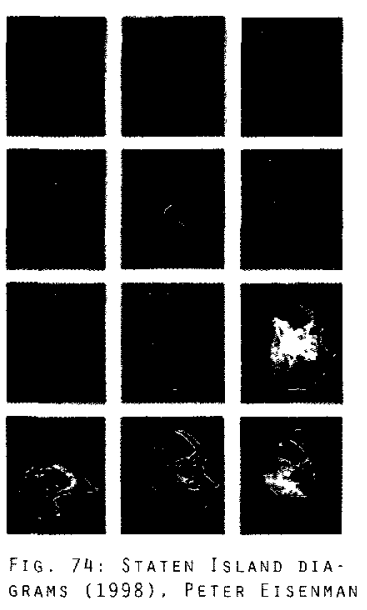
GRAMS (1998), PETER EISENMAN

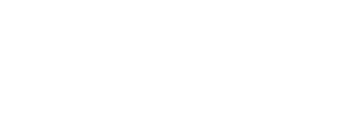
(n) 
architectural practice and anterior traces then, are always invisibly present as they form the very foundations for representing a new architectural presence. ${ }^{27}$ Also, indirectly referencing the anteriority of architecture in The Space of the Encounter, Daniel Libeskind speaks of the architectural drawing as, "as much a prospective unfolding of future possibilities as it is a recovery of a particular history to whose intentions it testifies and whose limits it always challenges. ${ }^{\prime 28}$; inferring that architectural drawings intrinsically represent the entire history of representational developments which formed their methodological foundation. ${ }^{29}$ Though each reference is referring to architectural representations, they indirectly relate to the notions of the traces of anteriority, interiority and exteriority in architecture which Eisenman earlier explored through the use of the diagram.

Utilizing Eisenman's notions as a significant conceptual influence, this inquiry continues to further develop by constructing a 'cabinet of wonder.' The 'cabinet' curates the architectural potentials unraveled throughout this inquiry, acting as a physical diagram of the work at hand and providing a means to continue exploring the architectural potentials contained within.

\footnotetext{
1 Confurlus, Gerrit Daldalos vol 74, 2000

2 Garcıa, Mark The Diagrams of Architecture p 22

3 ıbıd Garcla p 18

4 Berkel, Ben van, Bos, Carolıne "Diagrams" Op cit, The Diagrams of Architecture ed Garcla, Mark p 224

5 Pai, Hyungmin "Scientific Management and the Birth of the Functional Diagram" Op cit, The Dragrams of Architecture ed Garcia, Mark p 76

6 Eisenman, Peter "Diagram An Original Scene of Writing" Op cIt, The Diagrams of Architecture ed Garcia, Mark p 94

7 Zaera-Polo, Alejandro "Between Ideas and matters Icons, Indexes, Diagrams, Drawings and Graphs" Op cit, The Diagrams of Architecture ed Garcia, Mark p 240

8 ibid Zeara-Polo p 240

9 Deleuze, Gilles and Felıx Guattarı "A Thousand Plateaus Capitalısm and Schizophrenıa "Trans Brian Massumı Minneapolis University of Minnesota Press, 2003 p 511

10 ibid Berkel, Bos p 224

1 Kwinter, Sanford "The Harnmer and the Song" Op cit, Diagrams of Architecture ed Garcia, Mark p 124

11 Eisenman, Peter Eisenman Inside Out Selected Writungs 1963-1988 p 29

12 Dijk, Hans van "Interview Peter EIsenman"

14 Frank, Suzanne Peter Eisenman's House VI The Client's Response p 23

15 ibid Frank p 23

16 Davidson, Cynthia, ed Tracing Eisenman p 57

17 bid Davidson p 59

18 bid Frank p 23

19 Ibid Davidson $p 104$

20 ibid Frank $p 23$

21 ibıd Frank p 24

22 Moneo, Rafael Theoretical Anxiety and Design Strategies p 169

23 Eisenman, Peter “Diagram An Original Scene of Writing' Op cit, The Diagrams of Architecture ed Garcla, Mark $p 98$

24 ibid Eisenman p 93

25 Eisenman, Peter "The Diagram and the becoming Unmotivated of the Sign" Op cit, The Diagrams of Architecture ed Garcla, Mark p 205

26 ıbıd Eisenman p 210

27 El-Bızrn, Nader "Imagination and Architectural Representatons" Op cit , From Models to Drawings, p 35

28 Libeskınd, Daniel The Space of Encounter Universe, 2000 p 84

29 ıbıd El-Bızrı p 35
} 


\section{CHAPTER 5 :}

\section{CABINET OF WONDER}

"The expression of wonder stands for all that cannot be understood, that can scarcely be believed. It calls attention to the problem of credibility and at the same time insists upon the undeniability, the exigency of experience." -Stephen Greenblatt $^{1}$

The cabinet of wonder refers to the cabinets of curiosities or Kunstkammers that originated in Renaissance Europe as encyclopedic collections of types of objects whose categorical boundaries were yet to be defined. Cabinets of curiosities would often serve scientific advancement when images of their contents were published. The term cabinet, however, originally described a room rather than a piece of furniture. Eventually a cabinet came to be signified as a collection of objects or art that stimulate one's intellect. ${ }^{2}$

The wonder of these chambers referred to both the objects displayed and the subjective state they inevitably induced in viewers. But why were such collections particularly rampant during the late sixteenth and early seventeenth centuries? The answer according to Lawrence Weschler in Mr. Wilson's Cabinet of Wonder "lies in the avalanche of marvelous new stuff that had suddenly begun pouring over the transom into a previously parochial, hidebound, closedEuropean subcontinent. In particular, the stuff of the New World." ${ }^{3}$

Wonder was Europe's initial response to the emotional and intellectual experience of the radical New World where essentially, anything could be deemed possible and - vice versa - nothing could be deemed impossible. ${ }^{4}$ Weschler quotes the observations of Stephen Greenblatt In Marvelous Possessions: The Wonder of the New World where he explains, "The expression of wonder stands for all that cannot be understood, that can scarcely be believed. It calls attention to the problem of credibility and at the same time insists upon the undeniability, the exigency of experience. ${ }^{5}$ This sensation of wonder was what many of the cabinets at that time wished to preserve for observation and study. Wunderkammerns weren't simply displays of artifacts found in the new world

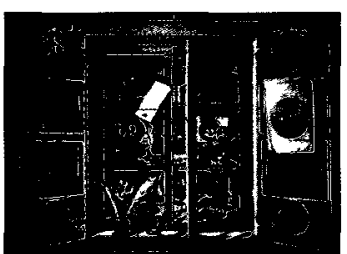

FIG 77 A CABINET OF CURI OSITY (1690) DOMENICO REMPS

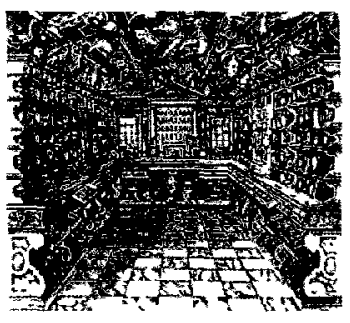

FIG 78 CALZOLARI'S MUSEUM (1522) FRANCESCO CALZOLARI 
but provocations aimed to expand the conceivable norms of social, educational and scientific understandings. For example, according to Weschler, "horns...were suddenly all the rage...rhinoceros horns, unicorn horns, sea unicorn horns, human horns etc...rhinoceros horns were real; and sea unicorns did exist so why couldn't unicorn horns or human horns exist as well?" Collectors, or Wunderkammer-men, were comparable to men of science because they looked upon elements of wonder as essential for enticing the study and discovery of natures secrets. To them, 'wonder' was understood as a form of learning that teetered between ignorance and enlightenment where one's unknowing began knowing. ${ }^{7}$

Though the element of wonder is underlined throughout the design process, it is important to note that some definition is necessary in order to guide and converge the unlimited diverging developments that potentially develop. For instance, the criteria to develop a 'cabinet' which contains this thesis inquiry, demonstrates how spatial development techniques generate and inspire highly imaginative spatial arrangements that can develop through the application of exterior influences or criteria such as program, client input, site analysis, zoning, materiality etc. The methods used to develop our 'cabinet of wonder' are analogous and applicable to those used for developing a full scale architectural project. By developing a relatively simple object however, we can eliminate the multitude of exterior influences common to a full-scale architectural project; allowing for just a portion of a potential overall architectural project to be highly developed. Thus, the resultant cabinet unit is perceived as a microcosm of the potential architectural space(s); a diagram of the architecture that exists within the traces of its own design. In a review on Bredecamp, Francesaco Fiorani stated that "The Kunstkammer was regarded as a microcosm or theater of the world, and a memory theater. The Kunstkammer conveyed symbolically the patron's control of the world through its indoor, microscopic reproduction. ${ }^{8}$ This allows for a high degree of development of a microcosm of a potential overall architectural project. Our cabinet will, in turn, allude to the potential spatial development of its containing space.

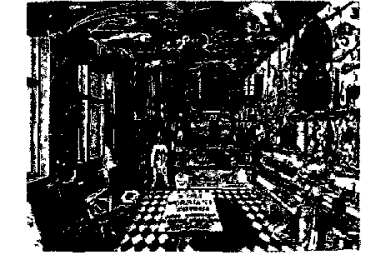

FIG 79 MUSEI HORMIANI HISTORIA (1655) OLE HORM

CLOSEO

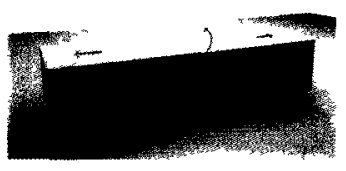

OPEN

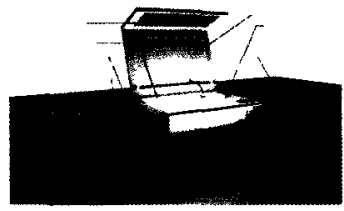

FIG 80 CAEINET OF CURIOSI TIES (DIGITAL RENDERINGS, 2011), JARED HAGENS
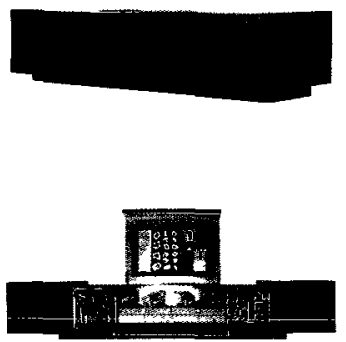

FIG 81 CABINET OF CURIOSITIES (2011) Jared Hagens 


\section{DESIGN PROCESS DIAGRAM \\ PROTOTYPE 7: CABINET OF WONDER}

The following diagram is a summary of the design process steps taken towards realizing the resultant Cabinet of Wonder. Though not all design variations are fully documented due to the duration and complexity of this process, they remain (as argued) not-present in the form of anterior, interior and exterior traces. Each documentation or summarization (variations 1-7) are alternative explorations in form, materiality and constructability - some influenced by others or by the intentional application of prototype development criteria. Such criteria (or exteriorities) are inclusive of time and budget constraints, constructability, advisor recommendations, changes in program or scope of work, evolving intentions and necessary alterations learned through trial and error.

Originating from Speculation III, model translations were constructed and documented at various orientations which provoke further imaginative spatial interpretations to potentially continue in the design exploration(s). As discussed in previous chapters, each variation inevitably results in newly acquired knowledge and therefore alternative imaginative associations to potential variations in form, construction and continuation as a 1:1 architectural prototype. As the end result of this process, it is evident that Prototype 7 or, the Cabinet of Wonder, successfully demonstrates the goals which speculations set out to achieve:

1. To develop an architectural methodology that challenges the strictures of architectural conventions and is no more or less capable of producing architectural artifacts

2. To demonstrate how the axonometric can be valued as a generator for design as opposed to a representation of design.

3. To demonstrate how resisting conventional standards leads to new discoveries in theory and practice that, in turn, propagate further discovery and knowledge. 
The cabinet of wonder at first acts as an illusion perceived as a generic bench that only subtly hints to being, and containing within, something 'other' than Itself. The intention of this subtlety is to ignite a sense of intrigue and wonder as to the potentials contained within. As a result, the 'bench' attempts to subconsciously educate notions of Interiority, Anteriority and Exteriority through making one aware of their role as a participant; someone literally 'exterior' to an 'interior' of what was originally perceived (via prior understanding) as a bench only later understood as a cabinet that entices a sense of wonder and intrigue through subtle constructed concealment. To prolong the sense of wonder, the cabınet is revealed in a series of stages, each of which, contain further concealed compartments. Upon opening the cabinet, one is greeted with three highly glossed colours that sharply contrast the monotone exterior wood finish. The colours red, green and grey are references to Peter Eisenman's House VI, which was an initial bibliographic inspiration to our inquiry. Red and green however are used to symbolize the combination of both architectural theory and practice methodologies, to form a 'grey-zone' which serves the drawing inquiry.

Similarly, the cabinet adopts this method of unfolding in stages; multiple trajectories reveal a carefully controlled 'field of operations' and process used within our argument. Concealed in the left wing is the thesis biblıography display which symbolizes the traces of anteriority found throughout the thesis. So too, all the documents stored within the cabinet represent the process or, traces of anteriority of the cabinet's development. According to Horst Bredekamp's analysis on cabinets of curiosities in The Lure of Antiquity and the Cult of the Machine: The Kunstkammer and the Evolution of Nature, Art and Technology "the juxtaposition of such disparate objects encouraged the finding of comparisons, analogies and parallels and favoured the cultural change from a world viewed as static to a dynamic view of endlessly transforming natural history."

Within the display case are the physical model explorations conducted which clarify and develop the potential spaces found within earlier drawings. The
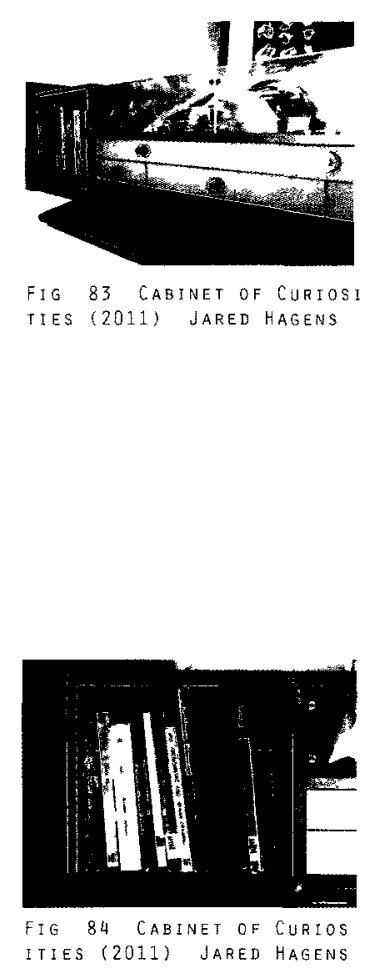

FIG 83 CABINET OF CURSOSI
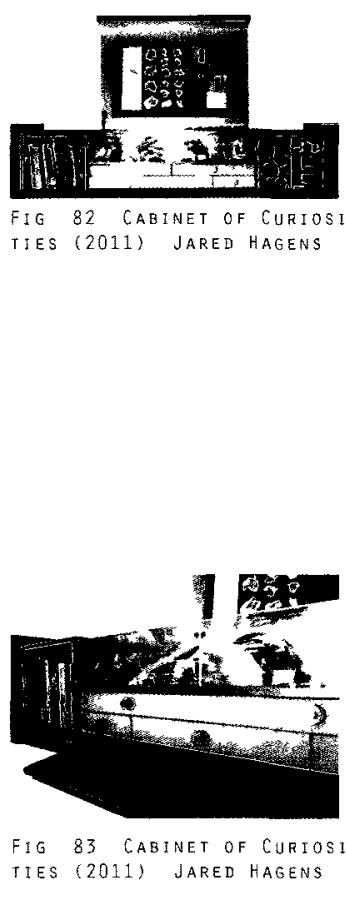

TIES (2011) JARED HAGENS 
models are organized to represent and document these explorations and point out the necessity of order for controlling the unlimited potentials of the design process. The models, as with every any other stored item, can be viewed as anterior traces of the thesis inquiry. Most importantly however, the models act as representations or documented traces of interiority found within the drawings they sought to clarify. The models are subjective interpretations and conceivable translations of the impossible spaces found within earlier drawings. And as stated in the documentation of their development process, these interpretations vary in translation due to changes in materiality, construction methodology, and most importantly, changes in imagination and perception caused by prior knowledge acquired through process and experimentation. Found within their interiority, are traces of the unlimited architectural potentials which their construction, materiality, proportions, patterns, etc. all allude too. Found within too, are the imaginative interpretations of participating observers whose own perceptions continue the potentially infinite exploration of potential architectural spaces interior to the models, made evident when simply altering the orientation of a model to formulate alternative interpretations.

Stored below the display case are the drawing explorations from which the original models were developed. The explorations are organized in separate stages to clarify the process from which original inquiries developed into a thesis inquiry. Similarly to the models, these documents represent traces of interiority and anteriority but also, are interior and anterior traces of the cabinet of wonder in which they are contained. Speculations, indeed!

\footnotetext{
1 Greenblatt, Stephen. Marvelous Possessions The Wonder of the New World. Chicago: University of Chicago Press, 1991, p. 13 2. Weschler, Lawrence. Mr. Wilson's Cabinet of Wonder. p.77

3 ibid Weschler p.77

4. ibid. Weschler p.77

5. ibid. Weschler. p.79

6. ibıd. Weschler. p.80

7. ibid. Weschler. p.89

8. Fiorani, Francesaco. Renaissance Quarterly 51.1. p.268

9. Bredekamp, Horst. The Lure of Antiquity and the Cult of the Machine The Kunstkammer and the Evolution of Nature, Art and Technology.
}
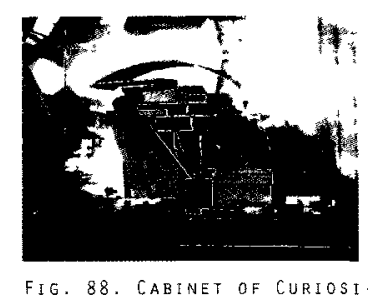
ties (2011). Jared hagens

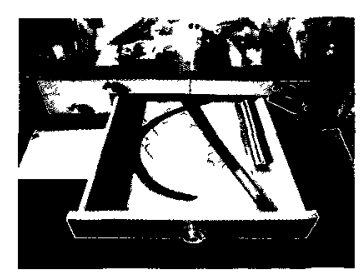

FIG. 89: CABINET OF CURIOSITIES (2011), JARED HAGENS 


\section{TOWARDS A CONCLUSION}

This study argues that Speculations illustrate the possibility to challenge conventional axonometric representational techniques and practices by demonstrating, through a continuous design development using models, a potential to evoke potential architectural spatial arrangements within the unrestricted database of the imagination. Speculations demonstrates how axonometric drawing methodologies hold within their anterior and interior traces, the potential to be manipulated, altered and/or developed into alternative methodologies capable of confronting preconceived habitual uses. As argued, axonometric representation in current architectural practices has mainly developed into a formal representation and communication tool for a finished design or idea. These are often, if utilized at all, the end product of the design process and are rarely utilized as a method for generating ideas and design in the initial stages of architectural development. It is through Speculations, that the accepted strictures of axonometric tendencies become apparent. In other words, typical axonometric uses are as restrictive as one allows them to be, and Speculations open up the unlimited potentials that reiteration offers to the architectural design process and discourse.

This thesis encountered Daniel Libeskind's Micromegas, El Lissitzky's Prouns, Josef Albers' Structural Constellations and Peter Eisenman's theoretical evolution of notions of Anteriority, Interiority and Exteriority of Architectural Diagrams, revealing the significance of the use of axonometry in the architectural discourse. The resulting reframing intended to serve as a tool for the principle argument of this thesis; Speculations, defined as architectural diagrams, could indicate an alternative and inspiring strategy to approach the architectural design process by integrating provoked imaginative speculative spaces prior to conducting any architectural production. In turn, this allows for the design process to initiate and develop in accordance with, and from, unrestricted imaginative influences as opposed to the limitations imposed when one is invited to conform to practicing accepted norms.

Daniel Libeskind's Micromegas indicate how Speculations are operational in nature; imposing a process that is neither pre-determined nor arbitrary.

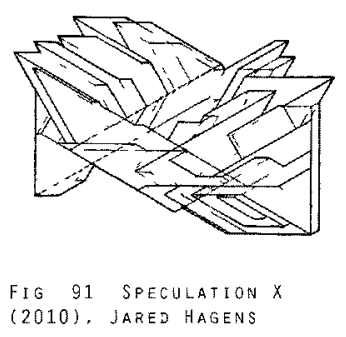


Speculations prevent one's imagination from forming a reducible definition or understanding of the perceived object(s); existing as neither a physics nor a poetics of space. ${ }^{1}$ Speculations illustrate illusionary characteristics which avoid perceptual traps allowing one to imagine unlimited (or zero) potential spatial formal arrangements. And, as argued, this ability to create perceptual shifts, is also comparable to Josef Albers' Structural Constellations which allow for objects to form both/and or neither/or relationships. ${ }^{2}$ Both Libeskind's and Albers' works recognize the role of the spectator's creative imagination as necessary to the realization of their intentions; this extends to Speculations. ${ }^{3}$ According to Robin Evans, Lissitzky's Prouns also greatly depended upon this for his painterly transformations into architectural representations. ${ }^{4}$ And much like the intention to develop Speculations as a departure from axonometric practice tendencies, Lissitzky's Prouns were a departure from the confinements dictated by the strictures of Modernism, Constructivism and Suprematism. ${ }^{5}$

This inquiry has sought to reveal just a few of the many relevant theoretical and practiced architectural methodologies which can be used to develop greater understanding and definition in the potential abilities and applicability of these Speculations for architectural design development. Connecting the characteristics of Speculations to those similar in works from artists and architects reveal such understandings, definitions and potentials but, none more so, than the work of Peter Eisenman. Eisenman's House VI served as an initial case study that emphasized the importance of process and helped direct the inquiry toward the understanding that architectural representations and Speculations could be defined as diagrams. Diagrams, which Eisenman claims, have anterior, interior and exterior traces of architecture in which any presence confirms the existence of those not present. Speculations reveal the wonder in their own cabinet(s) of curiosities.

\footnotetext{
1 Libeskınd, Daniel The Space of Encounter Universe, 2000 p 87

2 Auerbach, Anthony $W$ Structural Constellations Excurses on the drawings of Josef Albers c 1950-1960 p 206

3 ibıd, Auerbach 0214

4 Evans, Robin Architectural Projection $p 19$

5 Lodder, Christina Russian Constructivism London and New Haven Yale University Press, 1983 p 180
}

FIG 92 SPECULATION II

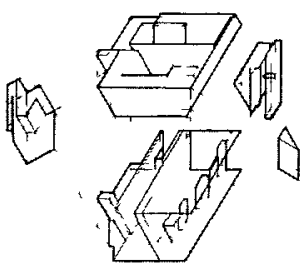
(2010) JARED HAGENS

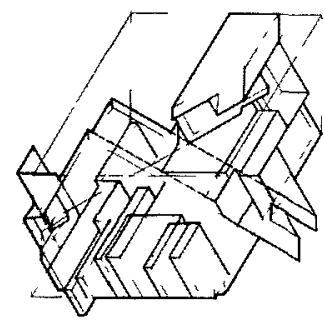

Fig 93 SPECULATION XIJI (2010). JARED HAGENS 

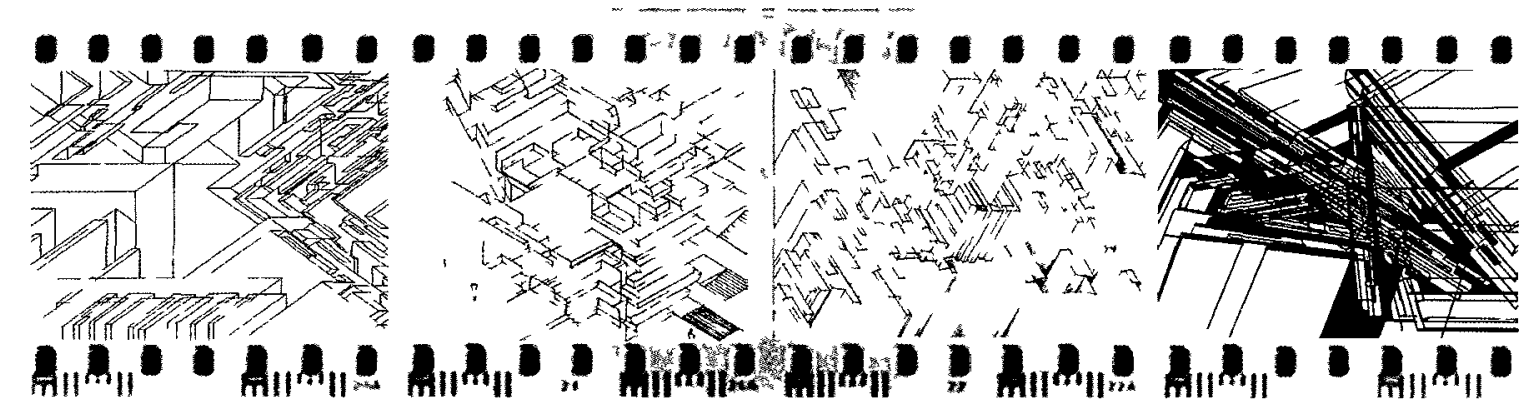

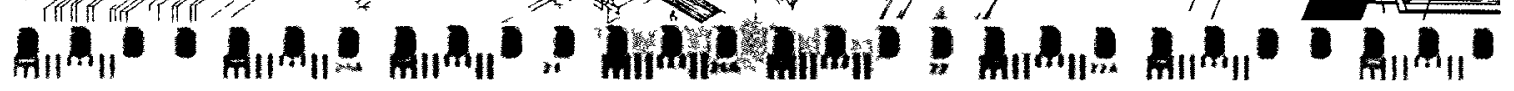
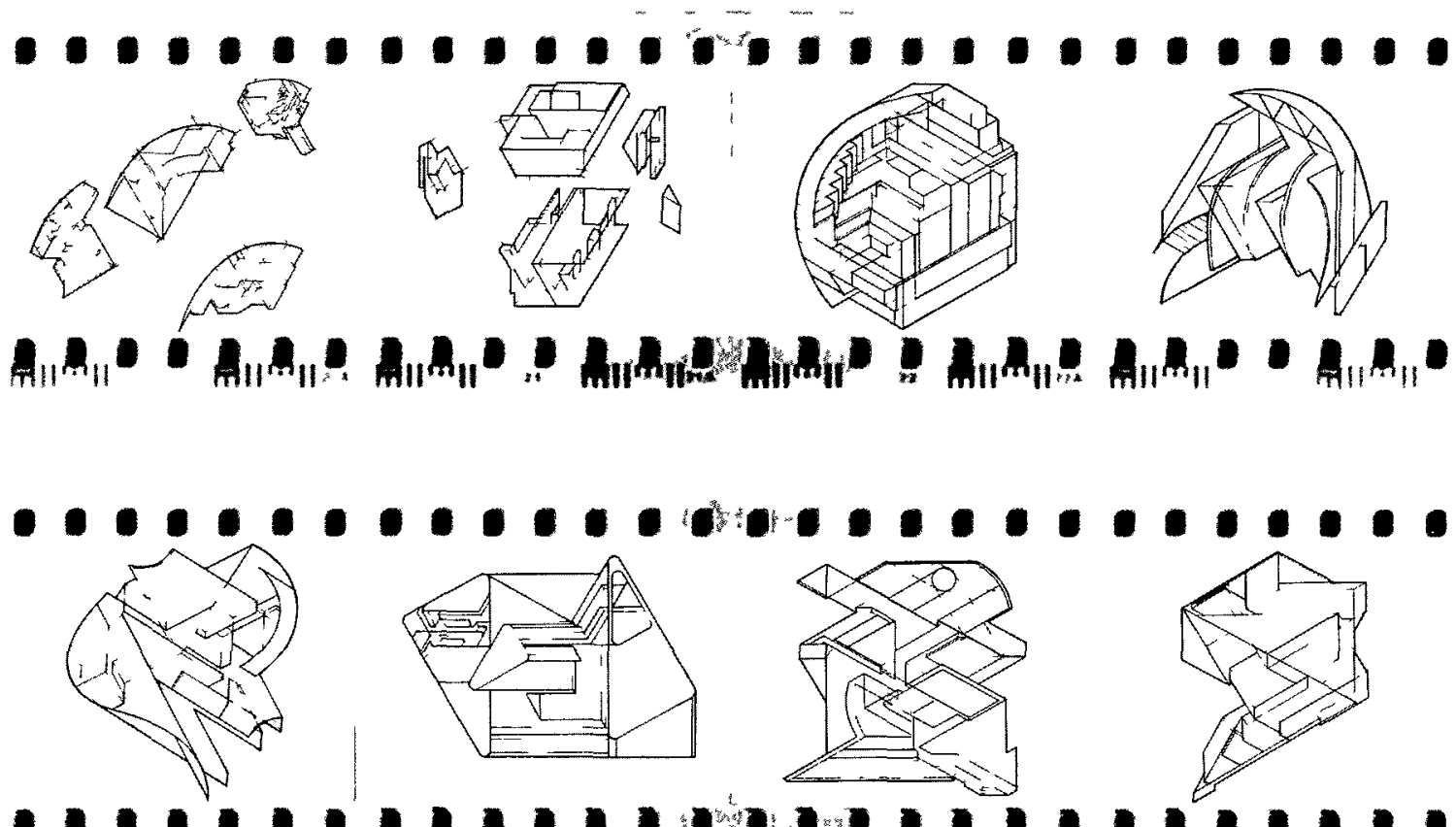

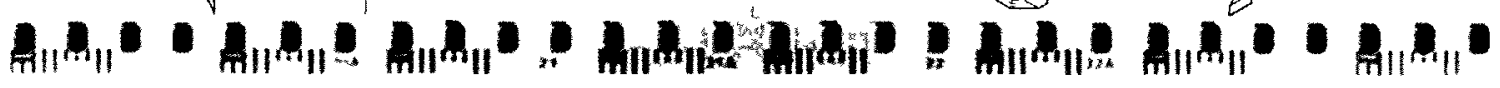

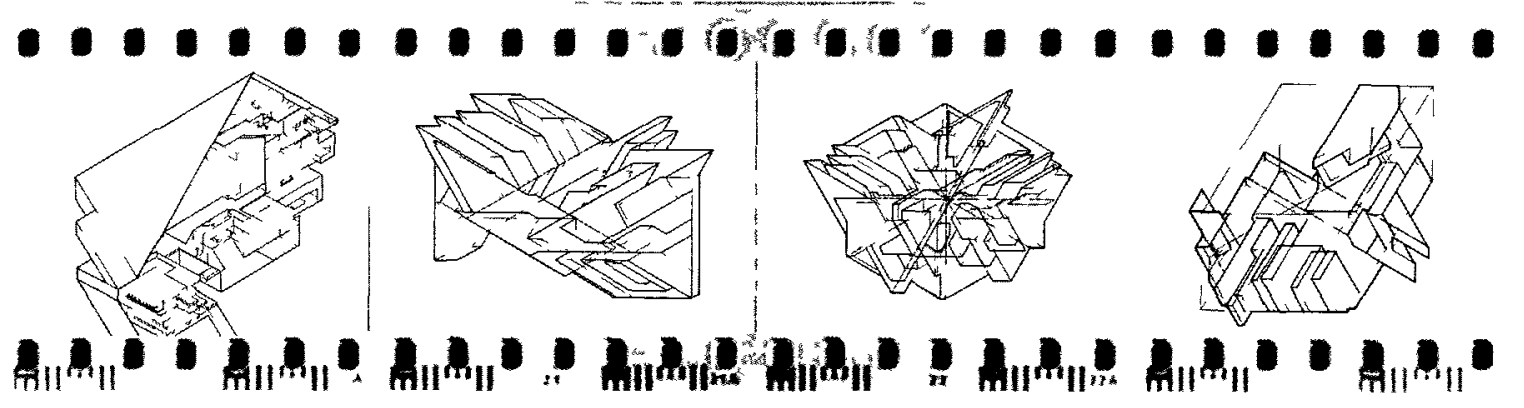




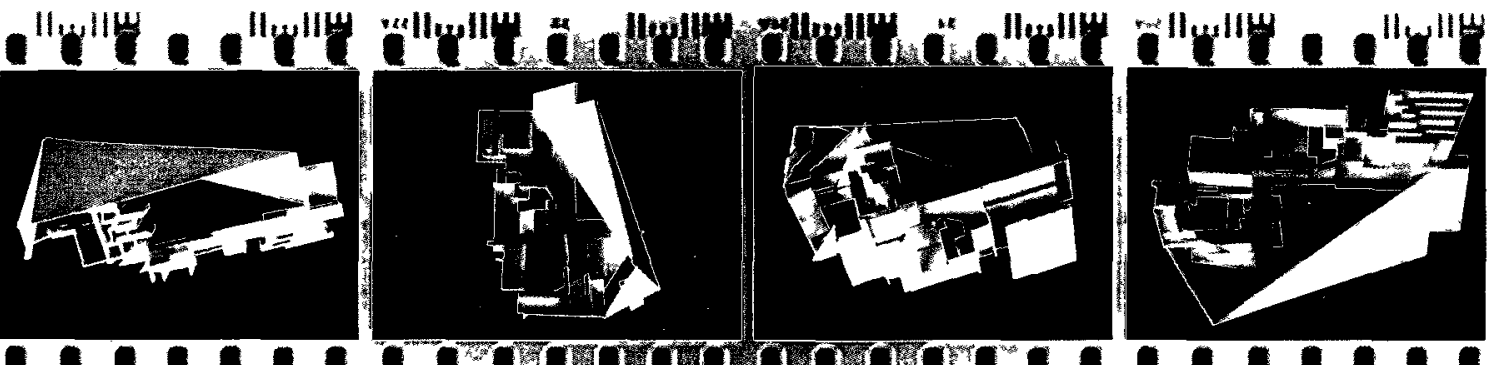

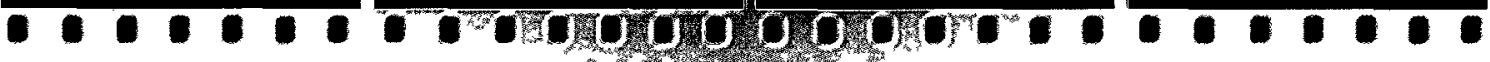

-

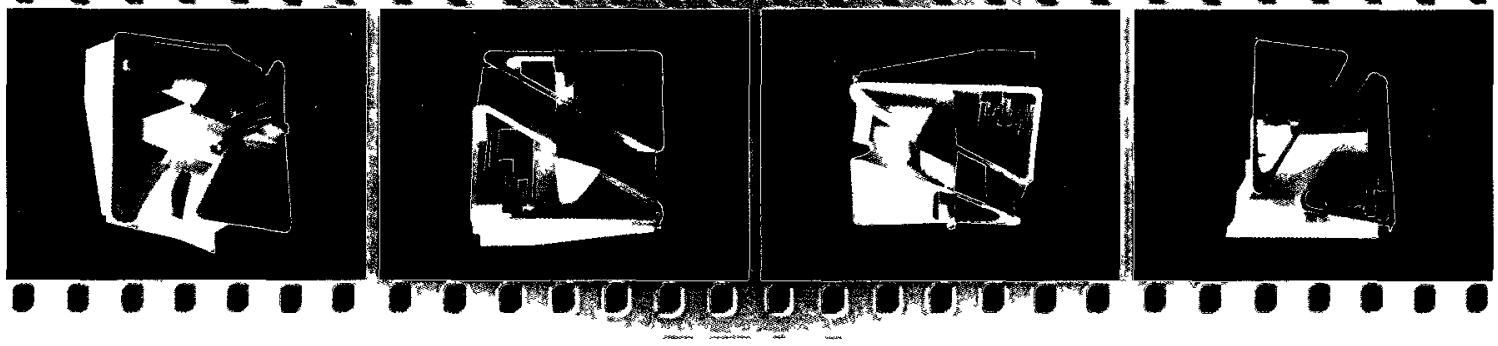

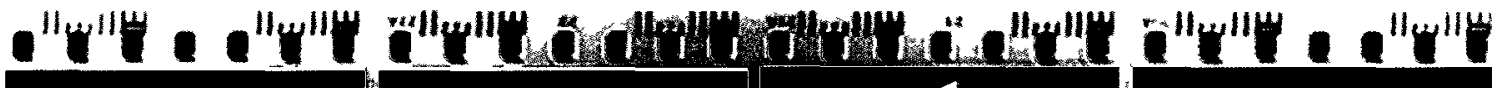
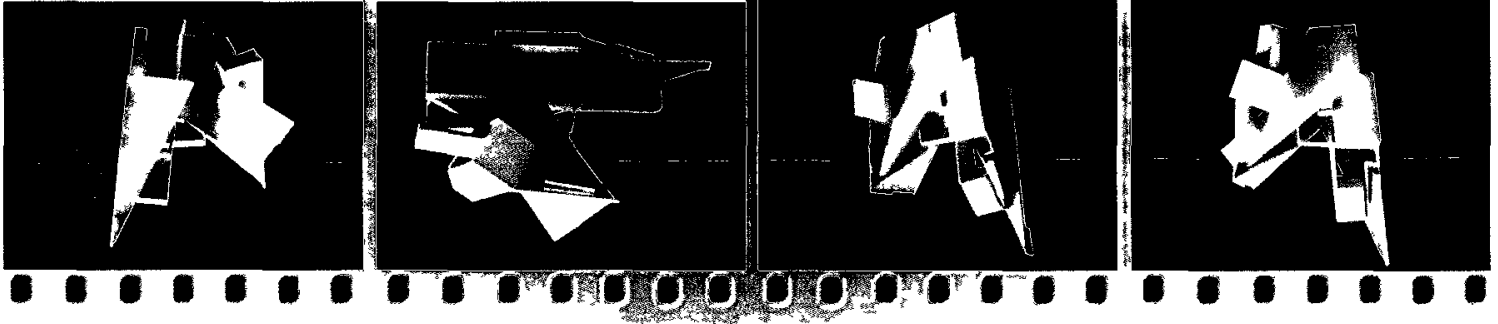

"
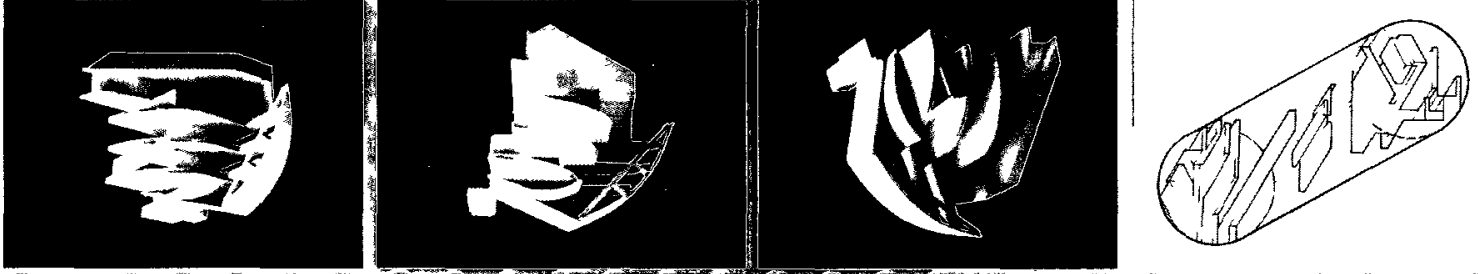

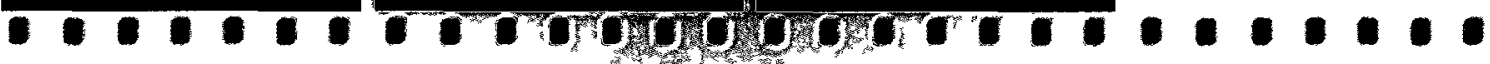



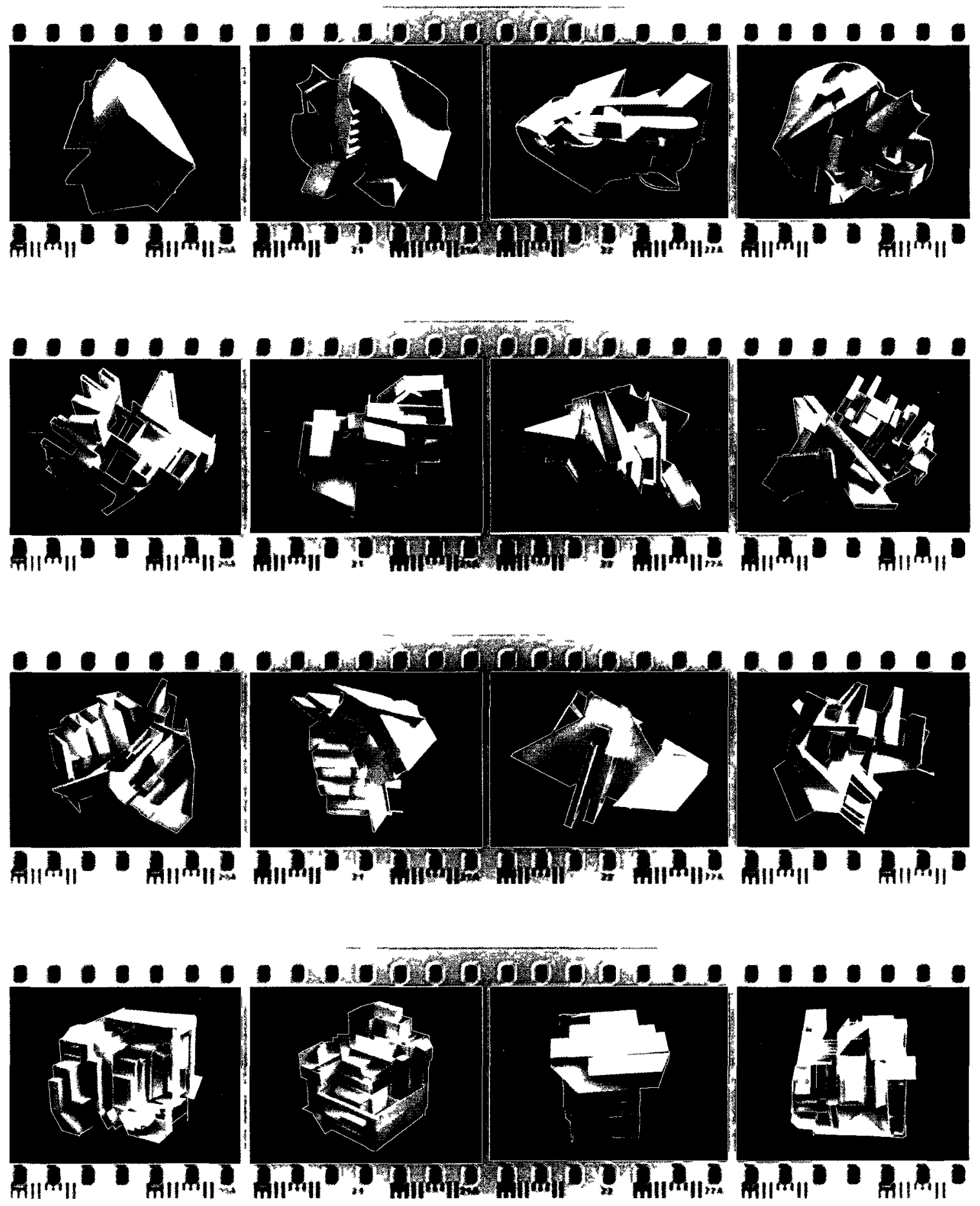

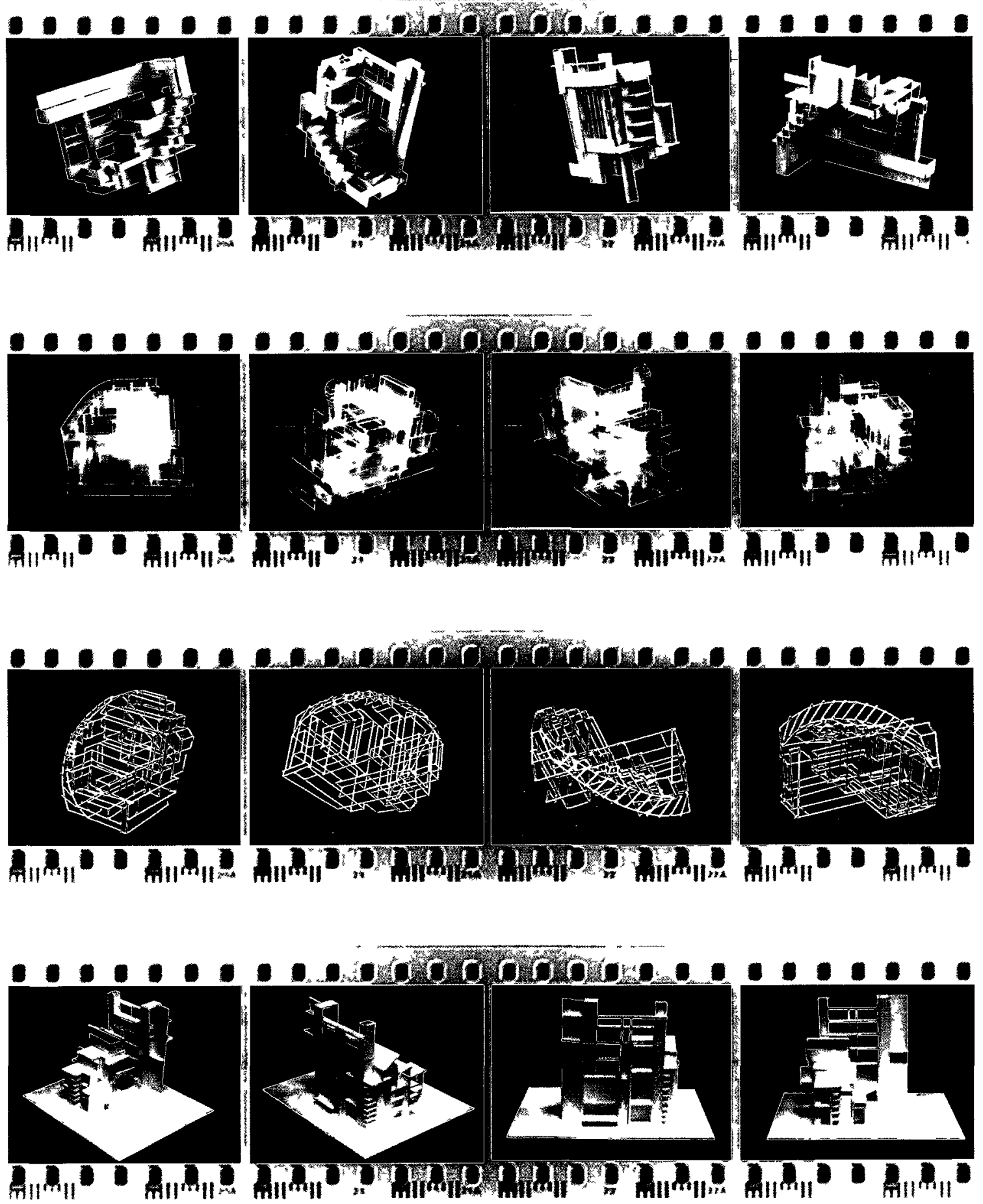


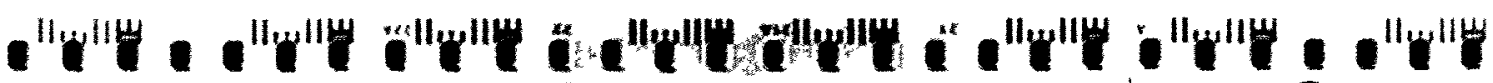
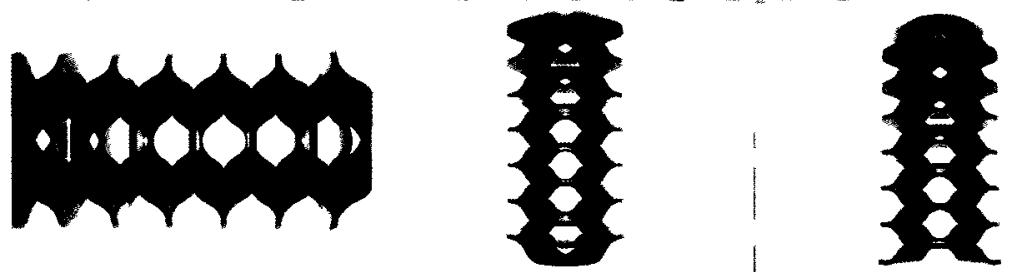

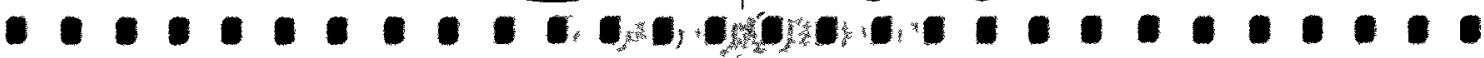

a
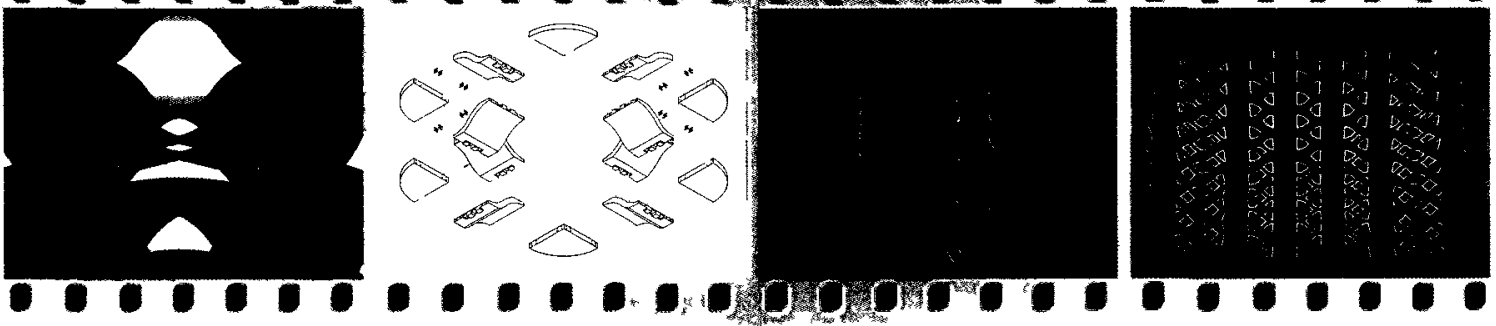

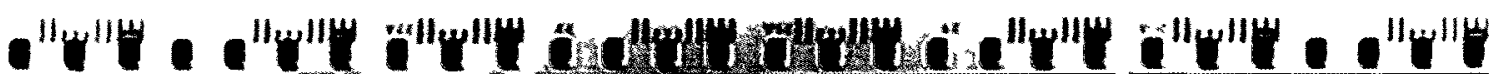
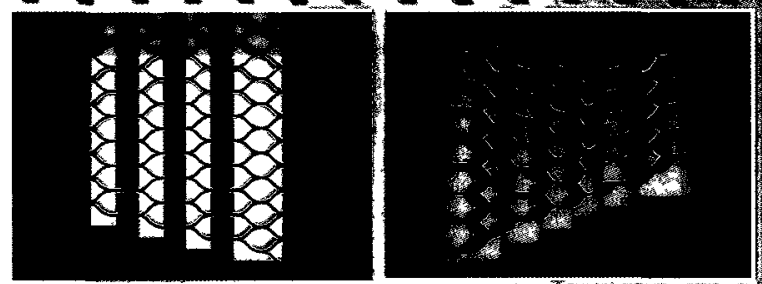
OEIPUit 6

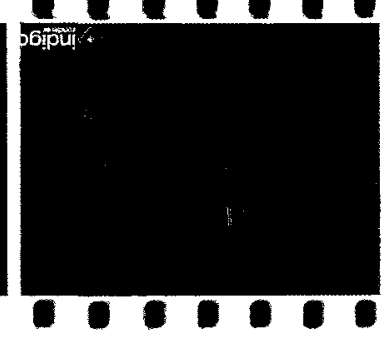

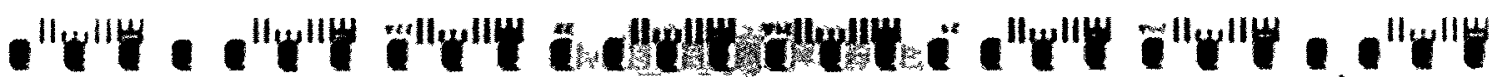
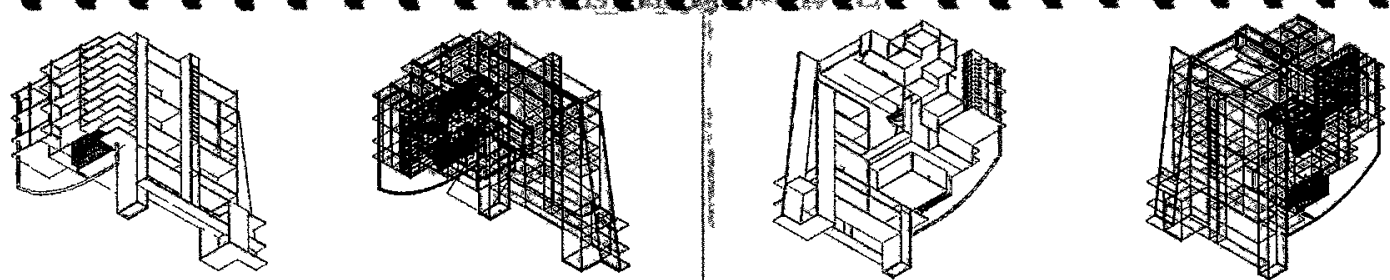

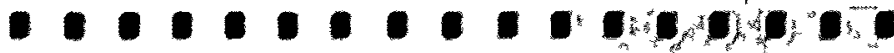




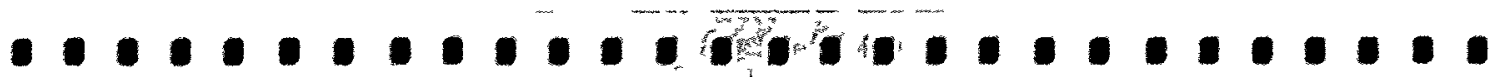
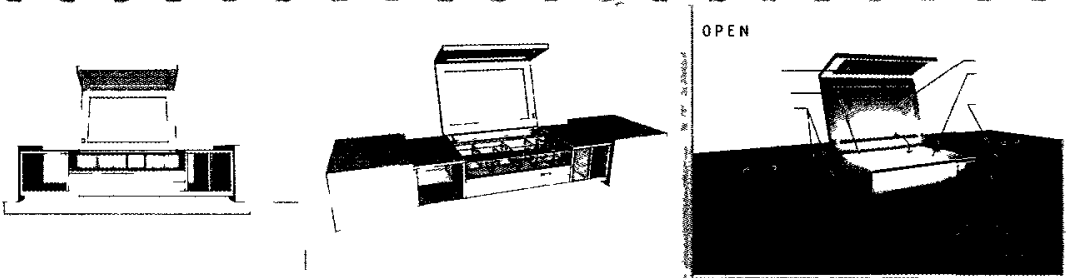

CLOSED

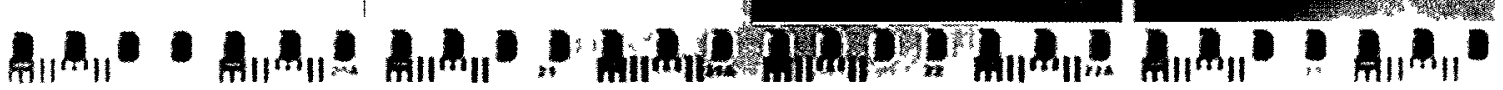

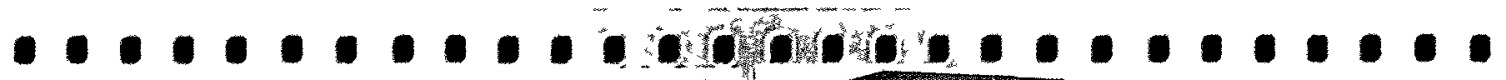
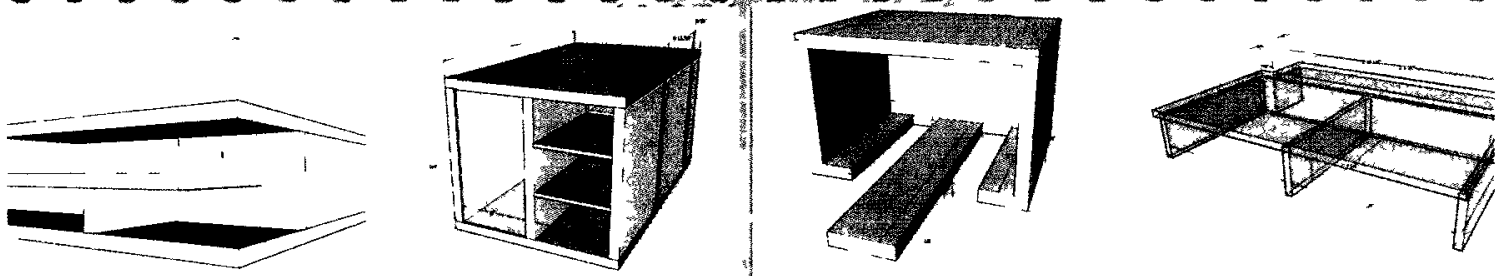

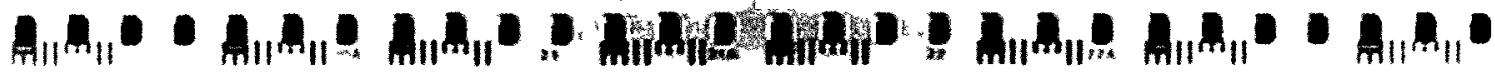

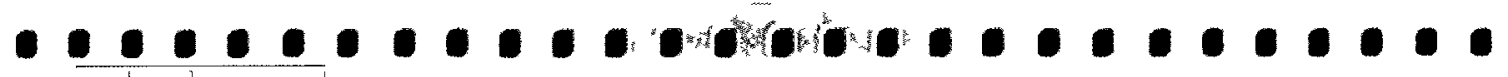

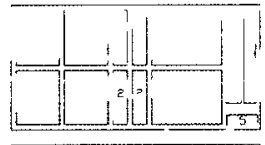

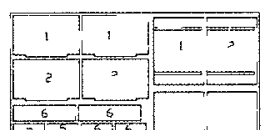
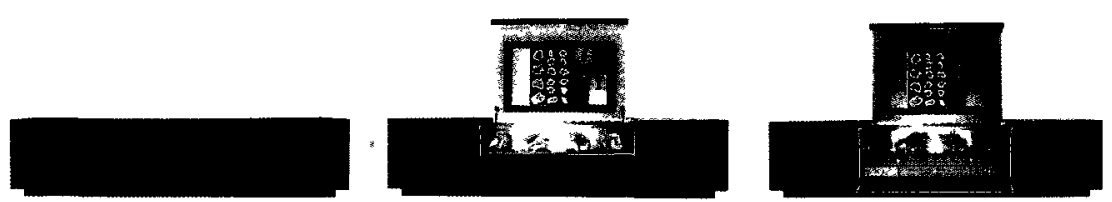

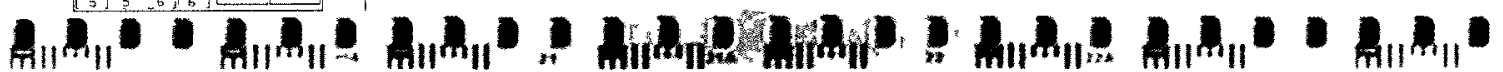

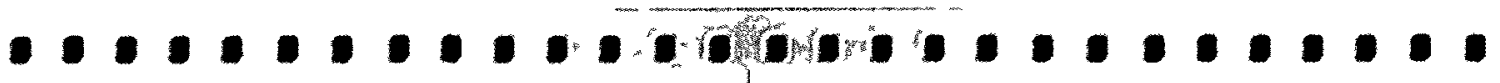
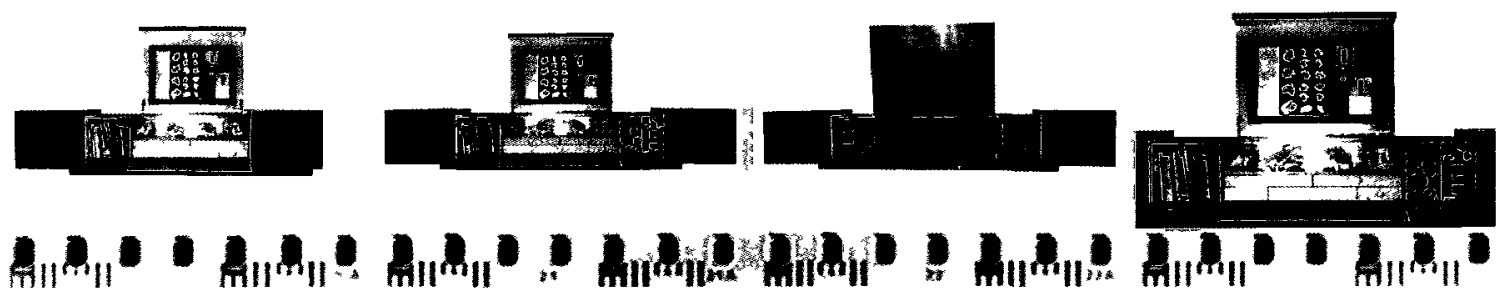

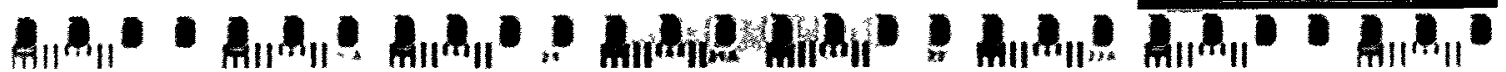



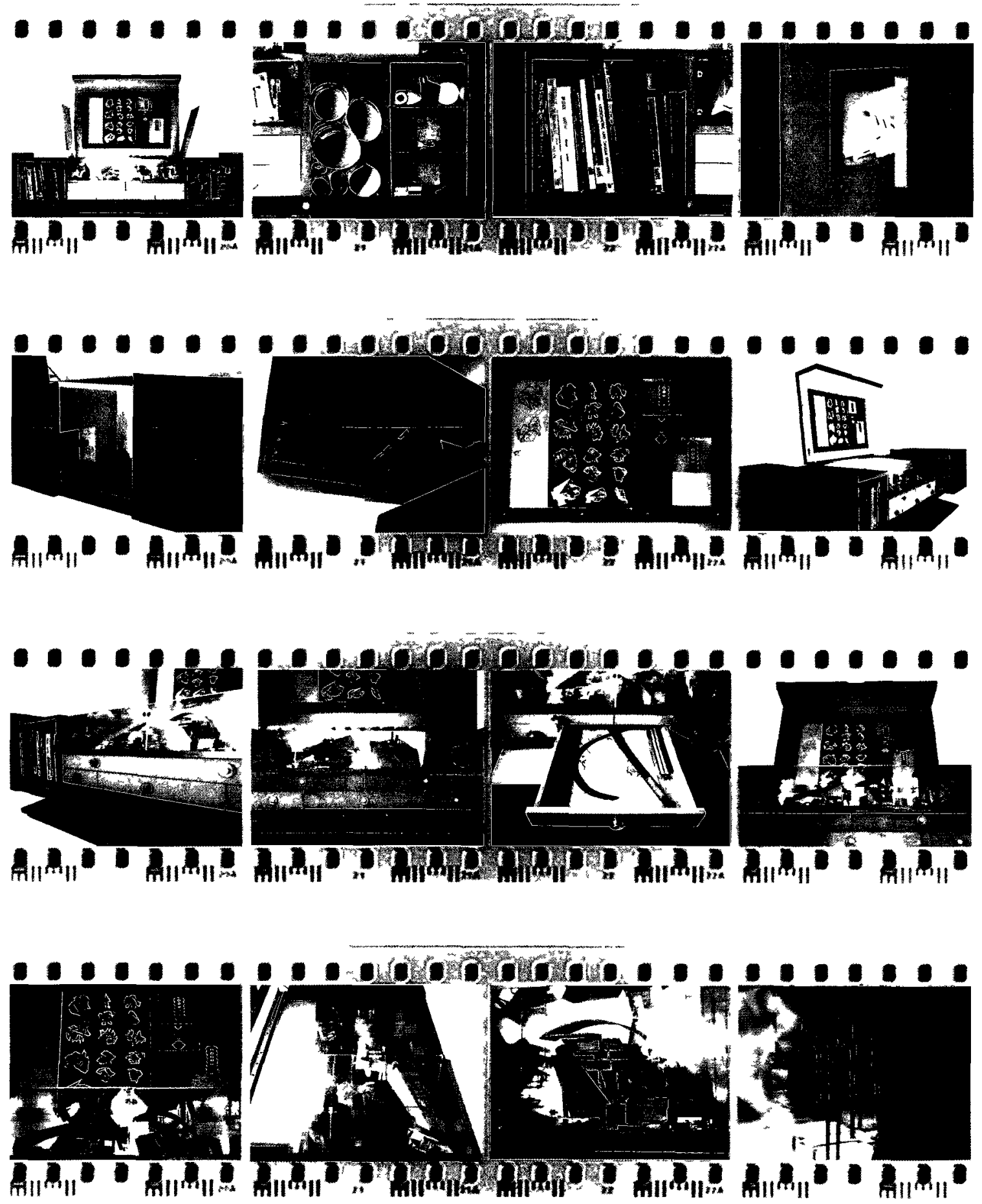


\section{APPENDICES}

\section{CONTENTS}

Appendix A: ARchitectural Representation \& CONVENTIONS

$P G .6164$

10 - ARCHITECTURAL REPRESENTATIONS

11 PRACTICE ARCHITECTURE TECHNIQUE + REPRESENTATION AUTHOR STAN ALLEN

12 EROM MODEls to Drahings EDItORS MarCo frascari jonathan Hale \& bradley Starkey

13 IHe Diagrams of architecture Editor mark garcia

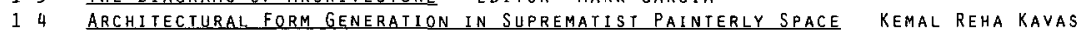

20 AXONOMETRIC DRAWING

21 PRACTICE ARChitecture IECHNique + Representation Author StAN Allen

30 - MICROMEGAS

31 Ihe space of encounter author daniel Libeskind

32 Practice ARCHITECTURE IECHNIQUE + REPRESENTATION AUTHOR STAN ALLEN

4.0 RESISTING BUILDING INFORMATION MODELING

41 from MODEls to Drawings Editors Marco frascari jonathan halle B badey Starkey

5.0 - COSMOPOIESIS

51 From Models to Drawings editors Marco frascari Jonathan hale \& Bradley starkey

52 PRACTICE ARCHITECTURE TECHNIQUE + REPRESENTATION AUTHOR STAN ALLEN

APPENDIX B: WORKS FROM EL LISSITZKY \& JOSEF ALBERS

$P G \quad 65-67$

10 - EL LISSITZKY'S 'PROUNS'

11 ARCHITECTURAL FORM GENERAIION IN SUPREMATIST PAINTERLY SPACE KEMAL REHA KaVAS

12 PRACTICE ARCHITECTURE TECHNIQUE + REPRESENTATION AUTHOR STAN ALLEN

13 Aachitectural MOdEL as MaCHine author a C SMITH

2.0 - Josef albers' 'Structural constellations

Appendix C: Perception, the Drawing gaze \& Imagination

$P G .68-69$

1.0 - PERCEPTION

11 ARCHIIECTURAL MODEL AS MACHINE AUthor a C SMITH

12 OPTICAL ILLUSIONS CREATOR RAMONA WINKLER

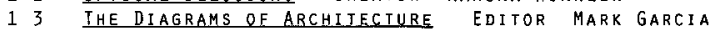

20 - DRAWING GAZE

21 ARCHITECTURAL FORM GENERATION IN SUPREMATIST PAINTERLY SPACE KEMAL REHA KAVAS

22 THE SPACE OF ENCOUNTER AUTHOR DANIEL LIBESKIND

23 ARCHIIECTUBAL MODEL AS MACHINE AUTHOR AC SMITH

24 IHE DIAGRAMS. OF ARCHITECTURE EDItOR Mark GarCia

30 - IMAGINATION

31 From Models to Drahings edtors marco frascari Jonathan hale \& Bradley Starkey

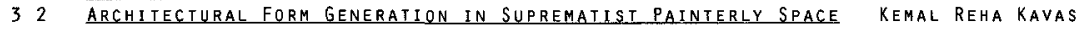

Appendix D: ARchitectural Scale MOdels

$P G \quad 70$

1.0 - ARCHITECTURAL MODEL as a Machine

1 I ARCHITECTURAL MODEL AS MACHINE AUTHOR A C SMITH

Appendix E: Peter EIsenman's House Vi: Design \& Process

10 - HOUSE VI

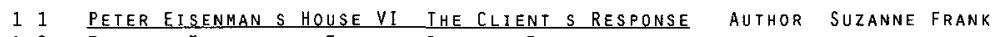

12 IRACING EISENMAN EDITOR CYNTHIA DAVIDSON

13 THEORETICAL ANXIETY AND DESIGN STRATEgIES AUTHOR RAFAEL MONEO

20 DECONSTRUCTION

$\begin{array}{llll}2 & 1 & \text { THE DIAGRAMS OF ARCHITECTURE EDITOR MARK GARCIA } \\ 2 & 2 \text { DECONSIRUCTION A STUDENT GUIDE AUTHOR GEOFFREY BROADEENT }\end{array}$

APPEndix F: ARchitectural Diagrams

PG $\quad 73 \quad 77$

10 - DIAGRAMS

11 Practice archliecture teshnique + Representation author Stan allen

12 THEORETICAL ANXIETY AND DESIgN STRAIEgIES AUTHOR RAFAEL MONEO

20 - ANTERIOR/INTERIOR/EXTERIOR TRACES

21 THE DIAGRAMS OF. ARCHIIECIURE EDITOR MARK GARCIA

22 THEORETICAL ANXIETY AND DESIgN STRAIEGIES AUTHOR RaFAEL MONEO

23 PRACTICE ARCHIIECTURE TECHNIQUE + REPRESENTATION AUTHOR STAN ALLEN

24 TRACING EISENMAN EDITOR CYNTHIA DAVIDSON

$\begin{array}{lll}2 & 4 & \text { TRACING EISENMAN EDITOR CYNTHIA DAVIDSON } \\ 2 & 5 & \text { FROM MODELS TO DRAWINGS EDITORS MARCO FRASCARI JONATHAN HALE \& BRADLEY STARKEY }\end{array}$

26 THE SPACE OF ENCOUNTER AUTHOR DANIEL LIBESKIND

30 - MODEL DIAGRAMS

31 ARChItectural MOdel as Maghine Author a C SMITH

40 The 'ABStract Machine'

41 PRACTICE. ARCHITECTURE TECHNIQUE + REPRESENTATION AUTHOR STAN ALLEN

41 THE DIAGRAMS OF ARCHITECTURE EDITOR MARK GARCIA

Appendix G: CABinet of Curiosities (Wunderkammern)

$P G .78$
PG 7172 


\section{APPENDix $A$ :}

\section{ARCHITECTURAL REPRESENTATION \& CONVENTIONS}

\section{0 - ARchitectural CONVEntions}

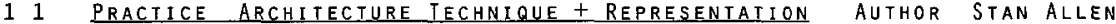

1) If conventional practice and theoretically driven critical practices are similarly structured, it cannot be a question of going beyond theory, or of leaving theory behind What is proposed here is instead a notion of practice flexible enough to engage the complexity of the real, yet sufficiently secure in its own technical and theoretical bases to go beyond the simple reflection of the real as given Not a static reflection of concepts defined elsewhere (either the codes of professional practice or the dictates of ideologically driven theory) but a rigorous forward movement, capable of producıng new concepts out of the hard logic of architecture's workıng procedures 1

2) Practice necessarily respects the verifiable laws that govern matter and forces, but it is also attentive to the fact that these laws operate without regard to consistency or established conventions of rational expression This attention to the gaps and inconsistencies In theory's fit to reality is, as TS Kuhn has pointed out, a tremendous source of invention and creativity It is precisely when practice and experımentation turn up inconsistencies in the "normal science" that new theories are produced 2

3) Too often, contemporary practice oscillates between mechanical repetition and shallow novelty Conventional practice renounces theory, but in so doing, it simply reiterates unstated theoretical assumptions The protocols of normal practice may be modified or adapted in response to circumstance, but are rarely challenged Design is reduced to the implementation of rules set down elsewhere If theory imposes regulated ideological criteria over the undisciplined heterogeneity of the real, the unstated assumptions of conventhonal practice enforce known solutions and safe repetitions ${ }^{3}$

4) Practice is not a static construct, but is defined precisely by its movements and trajectories There is not theory, there is no practice There are only practices, which consist in action and agency They unfoid in time, and their repetitions are never identical it is for this reason that the know-how of practice (whether of writing or design) is a continual source of innovation and change Tactical improvisathons accumulate over tnme to produce new models for operation But these new patterns of operation produced in practice are always provisional Inasmuch as they derive from experience and data, they are always open to revision on the basis of new experiences, or new data Delıberately executed, architecture's procedures are capable of producıng systematic thought serıal, precise, and clınıcal, somethıng that resembles theory but will always be marked by the constructive/creative criteria of practice 4

5) De Certeau's cunnıng optimısm suggests a notion of practice capable of continually reworkıng the lımıts of a dısciplıne from withın He offers a way out of the either/or dilemma of practice seen exclusively as a mechanical repettion (agent of institutional authority), or the neo-avant-garde positions of transgression or critique His view affirms that practices always unfold in time, moving on multiple and undisciplined trajectories At the same time it is a realistic vision, recognizıng that it is impossible to effectively operate outside of any discıplıne's "field of operations" 5

6) The purpose of writing is not so much to explain, or to justify a particular work of working method, as it is a contnual process of clarification In most cases, practical, experımental work comes first, and the writing down comes after ${ }^{6}$

7) "Theory needs a project a static construct, a persistent template of beliefs against which individual actions are compared, and tested for conformance" 7

8) In architectural production, the drawing of lınes is generally aımed at clarıfyıng ideas of space, a graphıc progressıon towards resoluthon in form ${ }^{8}$

9) Through drawing, the drawer is able to translate the seen, or make visıble the imagined, through economical means that reflect the fundamental bulding blocks of vision We tend to recognize a line, or a discernible contrast between one tone and another, as short hand for distinguishıng between two areas Boundary recognition then enables the discrimination of shapes, which may or may not conform to those that are familiar An understanding of those 'Invariant' aspects of the visıble world allows us to account for unfamiliar representations, to which further understanding is provided by the meanings, or 'affordances', that the perceived forms or environments have for the viewer ${ }^{9}$ 
10) Individually (or in combınation with other extracted forms) determıne how to manıpulate and develop the extractions into comprehensıble architectural spaces from which orthographic drawings can be developed ${ }^{10}$

11) An architectural drawing is an assemblage of spatial and material notations that can be decoded according to a series of shared conventions in order to effect a transformation of reality at a distance from the author The drawing as artfact is unimportant it can be just as convincingly described as a script, a score or a recıpe a set of instructions for realızıng a buildıng ${ }^{11}$

12) The architectural drawıng is transitive in nature, unıquely capable of producıng somethıng new from somethıng else ${ }^{12}$

13) Representation is not sımply content added onto building, but an entre intellectual and social construct that makes it possible to Imagine and construct new fragments of reality ${ }^{13}$

14) Design does not operate exclusively on the basıs of resemblance, but on the basis of abstract codes and a complex instrumentalIty ${ }^{14}$

15) The detachment of architecture's representational codes allows the designer to experıment with relative freedom But abstraction is more than an expedient By working with the abstract materials of number, proportion and interval, the architect can structure internal relationships and move smoothly between the visible and the invisible Invention follows, and paradoxically, a more complex appearance is produced than if appearance were the starting point 15

16) Visualization presumes that abstraction is a liabılity to be overcome, and attempts to bring the designer closer and closer to realIty ${ }^{16}$

12 Erom Models to Drawings editors marco frascari jonathan hale \& Bradley Starkey

17) architects have developed draftıng technıques that allow them to perform their thought-experıments in sets of graphıc analogies Workıng from a 'great un-digital database' of instinctive information pıcked up from experiences architects have worked out their thought-experıments on paper, dıscoverıng somethıng new about the bult world even though they have no new data ${ }^{17}$

18) They should instead be seen as the essental part of architectural production, rather than works of art in their own right 18

19) Consequently, in elaborating theories of architecture, drawings are always considered - and presented - as ancillary components rather than being treated as the most important architectural agents, since they carry embodied in them the non-verbal essence of architectural theory ${ }^{19}$

20) By reading and drawing 'architectural ımagıng' line-by-lıne, architects read and draw 'between the lınes' to foster architectural Imagination For architects, that which is between the lines is in reality earlıer - more archaic and genuine - than the lines themselves, for that which is shown invisibly is that which appears most powerfully and most directly in architecture Architecture is not represented directly rather, it is that which lies between the lines that appears most directly as it is able to manifest itself, reveal itself, give Itself, exhibit itself, arrive and materialize That which occurs in this invisible realm is not 'somewhere else, it is In the drawing itself the architecture that is able to be discerned in-between is not elsewhere ${ }^{20}$

21) The real architectural drawing does not result from a vision of the absent, but instead it provokes one Rather than resulting from the gaze aımed at it, the drawing summons insight by allowing the invisible to saturate the visıble, but without any attempt or claım of reducing the invisible to the visible lines of the drawing The drawing attempts to render visible the invisible as such, and thus, strictly speakıng, shows nothıng It teaches the gaze to proceed beyond the visıble Image into an infinity whereby something new of the invisible is encountered Thus the true drawing gaze never rests or settles on the drawing itself, but instead rebounds upon the visible into a gaze of the infinite ${ }^{21}$

22) Architectural traditions are rich in potential lessons and alternatives History offers ample evidence for an architecture result from a poetic translation of its representations 22

23) Even in their conventional forms, architectural drawings or models ('les maquettes', in distinction from the paradıgmatic sense of 
'models' as 'exemplars') do in some instances inspire originality and discovery, beyond the expedient descriptive functions or generative operations that they perform in presenting concrete or hypothetical expressions of current or future constructible architectural realities Moreover, the creative reception and adaptive assımilation of what architectural representations stimulate all reflect the Imaginative capabilities of the designer, the critic as well as the contemplatıng observer Imaginative associations and varıations determıne the potential unfolding of inventiveness in reference to the inspırational possibilites locked in time-honoured architectural representations in this sense, notable architectural drawings and models (maquettes') do not merely 'render the invisible visible as such', but they furthermore offer pointers and directives to events that carry manifold possibilities of realization, and are thus not reducible in their bearıngs to solely beıng geometrıcal or physıcal instruments that formally represent prospective or actual habitable structures ${ }^{23}$

24) This inquiry focuses on basıc phenomena associated with visual perception in view of examıning some of the multiple functions of ımagınation in architectural conventional representation in the effort to also critically rethınk the experiential and intellective condıtions of 'envisioning architecture in abstentia' 24

25) Invisibility conditions the possibilities of perceptual experiencing in terms of engulfing what is physically present by an active Imagınıng 25

26) drawing with a ruler and compass sufficed to signal geometry ${ }^{26}$

\section{IHE Diagrams of ARchitecture EDItOR MARK Garcia}

27) The diagram for me is a graphic representation of a concept There is no architecture without a concept Architecture is the materialization of a concept That first materialization is often a diagram because I cannot go from the concept to a building without first going through a whole series of stages, some are highly abstract and some are very material The diagram is one of the early steps in the process 27

28) Why use diagrams? Diagrams practice delays the relentless intrusıon of signs, thereby allowing architecture to articulate an alternative to a representational design technique $A$ representational technique implies that we converge on reality from a conceptual position and in that way fix the relationship between idea and form, between content and structure When form and content are superimposed in this way, a type emerges This is the problem with an architecture that is based on a representational concept it cannot escape exısting typologies In not proceedıng from signs, an instrumentalizıng technıque such as the diagram delays typologıcal fixation Concepts external to architecture are introduced rather than superimposed Instances of specific interpretation, utilization, perception, construction and so on unfold and bring forth applications on various levels of abstraction 28

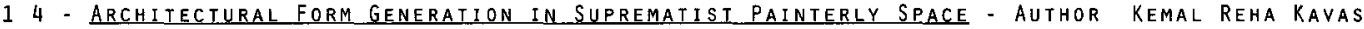

29) Robın Evans thınks that there is a close relation between the archıtects' Interest in two dimensıonal geometrical inquiries and theır belief in architectural representation as a form generative process Evans claıms that there are sensıble reasons for the architects' belief in the power of geometry ${ }^{29}$ For Evans, architects are consumers of geometry, If not its producers ${ }^{30}$ Evans argues that without "the architect's faith that geometrically defined lınes will engender somethıng else more substantial yet discernıble through the drawing," there would be no architecture ${ }^{31}$

30) In Evan's understanding, "architecture is considerably less than building" in contrast to the general idea that "architecture is more than mere buildıng" 32 The reason for Evans' specific comprehension of architecture becomes his assertion that "architects do not make buildıngs, they make drawings of buildings" 33

31) Robın Evans further assocıates the capacity of projection to convey "the generıc message inscribed in paper" with architectural representation ${ }^{34}$ Evans implies that ideas become "architectural" only if "they are given definition prior to being constructed "35 Evans argues that this quality of being "architectural" is what gives architecture its peculiarity because specifically, "the anterior definition of the object, whereby all significant decisions are normally taken before the thing itself is even begun" belongs only to the object of architectural representation ${ }^{36}$

32) Robın Evans states that, "architectural drawıngs are projections" 37

33) For Evans, "architectural representations" Indicate the direction opposite to the given ones, for architectural representation is 
Intended to be used so as to extract information to create objects, whıch are "embodıed" by the drawing prior to the objects' realızathon 38

34) For Evans, architectural drawings were erroneously seen to be solely dependent on the "purposes of construction and dissemınaton," which became justifications for the exıstence of these drawings ${ }^{39}$

35) Agreeıng with Lambert, Eve Blau and Edward Kaufman Invite the spectator to"look not only through these representations to the objects they depict but also at the representations themselves and the ways in which they convey information, ideas and attitudes about architecture" 40

36) Robın Evans argues that there are three sorts of "active ımagınation" those of the architect, the observer and the drawing itself 41 Evans argues that, at this point he does not associate these categories with "the mental faculty of the imaginıng" because this cannot be claımed for the part of the drawing ${ }^{42}$ Evans asserts that what he calls "active imagination" is closely related with the mode of projection used in the architectural drawing ${ }^{43}$

37) Evans argues that, as "the product of an intense Imagınation and a massive effort of ımagınative intellıgence," orthographıc projection is capable of emanating a great variety of effects, in each of its utilization ${ }^{44}$ immergences of axonometric projection and of the sketch Evans claıms that the sketch and the axonometric are modes of graphical expression belonging to two extremes of a polarity, which are respectively the "synthetic, indefinite, amorphous" that lacks "obvious geometry" versus the "analytic, exact, rectilınear that is full of obvious geometry" 45

38) Boıs suggests that "the internal logic of axonometry offers a critique of perspective's contradıctions" 46 For Leah Dickerman, axonometry creates "an a temporal, universalizıng and subject-less mode of spatial representation by dispensing analogy with human perception, breakıng the correspondence between viewpoint and vanıshıng point central to the conceptualızation of perspective as a model of sight" 47 Dickerman argues that axonometry constructs "an Irrationality, an Imagınary space, unconstraıned by the rationalIsm and discıplınary logıc of a sıngle, fixed viewpoint alıgned with a vanıshıng point" dictated by perspectives ${ }^{48}$

39) Robın Evans locates the axonometric between the perspectival and orthographic modes of projections as "an expeditious way of representing the third dimension without sacrificing the scale measure of the plan, elevation and section," namely the constituents of the orthographic set 49

40) For Evans, the perspective is the "mımetic" representation of "the way we see thıngs" usıng the "convergence of the "projectors, the array of imaginary lines on a single point" Evans states that, in contrast, in orthographic projection, which is mostly used in the "professional design and production" phases of architecture, the "projectors do not converge to a point but remain parallel" 50

41) does not "correspond to any aspect of our perception of real world" Therefore, axonometric projection might be thought to entall the "abstract and axıomatic" nature of the orthographic set claımed by Evans ${ }^{51}$

42) "So it is not surprising that orthographic projections are commonly encountered on the way to buildings, while perspectives are more commonly encountered comıng from buildıngs" 52

43) For Evans, these presentation drawings "propagate a completely defined Idea" and do not "test or modıfy" an unfinıshed Idea 53

44) Evans argues that the repudiation of the role of "active ımagınation" durıng the reading of the architectural projections may lead to theır evaluation as "a mere technıcal facılıtator" whıch asserts that "drawing can propagate thıngs but never generate them" 54

\section{0 - AXONOMETRIC DRAWING}

\section{PRACTICE ARCHITECTURE TECHNIQUE + REPRESENTATION AUTHOR STAN ALLEN}

1) the avant-garde visıon of a new world Perspective records what already exısts, whereas axonometric constructs that which does not yet exist 1

2) But these instrumental technıques are given a new meanıng in the context of avant-garde practice For these artists, the visual 
abstraction of these technıques - the indetermınacy of the represented spatial field - becomes primary Instrumentality may work agaınst the symbolic, but a new metaphysics of infinite space works against the instrumental A symbolic dimension is grafted onto these technical practices ${ }^{2}$

3) Axonometric has its origin in ancient visual practices, and Massımo Scoları has argued for a history of contnuous development of parallel projection alongside of perspectival projection Parallel projection appears whenever questions of measurability, predıction and verifiability arise Therefore it is not surprising that the earliest systematic description of axonometric projection occurs in the context of military use, where it was utilized to chart the three-dimensional trajectory of artillery projectiles In the eighteenth and nıneteenth centuries, axonometric drawing was taught in engıneerıng schools and its development and dissemınation was closely related to mechanızation and industrialızation ${ }^{3}$

4) axonometric combıned the immediacy of perspectival view with the measurability and transmissibility of orthographic projection Axonometric projection, origınating in the abstract and instrumental world of the technical disciplines, does not pretend to map visıon It is concerned instead with construction and consistency of measurement ${ }^{4}$

5) The reınterpretation of axonometrıc projection by avante-garde artists, as a vehıcle for unıversal, abstract thınkıng, was never fully Integrated into architectural practice As Yve-Alain Bols has pointed out, it is only in more recent practice - the projections of Daniel Libeskind or the axonometric models of Peter Eısenman, for example, where an investigation of the means of representation takes precedence over realized buldıng - that architects have fully exploited the implied reversıbılity of depth and foreground that characterizes axonometric projection ${ }^{5}$

\section{0 - MICROMEGAS}

\subsection{IHE SPACE OF ENCOUNTER - Author DANiEL Libeskind}

1) In any case, a drawing is more than the shadow of an object, more than a pile of lines, more than a resignation to the inertia of convention The act of creation in the order of procedures of Imagination, here as elsewhere, coincides with creation in the objective realm ${ }^{1}$

2) An authentic abstraction gives us what is most unique in incomplete but formalized levels of grasping objects it does so because at first uniqueness is given in an impure fashion, blended as it is with elements representing categories of experience which must be progressively extracted from the general alienation of over-qualified intuition of spathal structure This 'purification' attempts, through a series of successive steps, to realize the elımınation of intuitive content and numerical relations, and leads to ever more encompassIng (spherical) possibilities of configuration ${ }^{2}$

3) It is not a matter of piling superımposed hierarchies one on top of another, rather, the trajectory of intentions transposes content Into operation and at the same time displaces descriptive geometry by the structural The transformation of object into operation imposes a temporal dimension on this process, a process whose meanıng is not arbitrary and yet is not predetermined either ${ }^{3}$

4) My work attempts to express this ınadequacy at the heart of perception for which no (final) terms are provided, a lack of fulfillment which prevents manifestation being reducible to an object-datum Only as horizons, in relation to time, can forms appear in this exploration of the 'margınal' where concepts and premonitions overlap There is a presentation, but always accordıng to the mode of imperfection, an internal play in which deferred completeness is united with a mobilized openness The work remains an indefinite series because this dialectic cannot be halted As such, these drawings and collages develop in an area of architectural thinkıng which is neither a physics nor a poetics of space ${ }^{4}$

\section{PRACTICE ARCHIIECTURE TECHNIQUE + REPRESENTAIION AUTHOR STAN ALLEN}

5) But in this case the representations can only refer to other representations This work (even when constructed) remaıns locked within a limited scope of problems specific to the discipline of architecture, and its own internal history It is incapable of takıng advantage of the instrumental capacity of architectural projection to transform reality and thereby, of necessity, to engage the soctal 5 


\section{0 - Resisting Building Information Modeling}

\section{EROM MODELS TO DRAWINGS EDITORS MARCO FRASCARI JONATHAN HALE \& BRADLEY STARKEY}

1) However, in the light of the new possibilities generated by the use of electronic media, a different and passionate challenge of these ımmobıle and sterile cırcumstances is needed to alter the present perception of the nature, skılls and means that govern the concelving and makıng of architectural models and drawings ${ }^{1}$

2) "The new electronic ımagıng prevents ımagınıng, and the resulting representations promote acts of merely logıcal 'thınkıng about architecture' rather than bringıng archıtects, contractors, clıents and critics to thınk withın architecture ${ }^{\prime 2}$

3) Efficiency is the disposition to be motivated towards the satisfaction of one's final desires The problem of course is that in their search for the architectural 'final desıre', the computer programmers who have pre-determıned the digital encodıng cannot pınpoint the final cause of an imaginative architectural event As this is always an essential aspect of the specific conditions of an architectural mandate, and thereby undetermınable in advance, so they substitute it with the most common pseudo-final cause - the ultimate desire of entrepreneurs for financially profitable results Successfully substituting ongoing cosmopoietic tactics with cosmopolitan strategies, BIM is seen as a novel technology that is still under development, therefore justifyıng all of its varıous shortcomıngs ${ }^{3}$

4) The traditional design tools were analogical toois the square used on paper to guide the tracing of lines corresponded to the square used on site to guide the erection of walls Without a doubt the digital mımıckıng has been detrimental, but such programs as BIM are further removing from the process of conceiving of buildings the possibility of emotionally and bodily conjuring up of experimentations in architectural theory ${ }^{4}$

5) By the analogical nature of drawings, architects free themselves from a fixed modus operandi, which becomes habitual through the constant repetition of accepted building procedures 5

6) However, in drawing, designers take part in a mult-modal dialogue played out on a surface with visıble tracings Viewing and respondıng to their own drawn lınes, even as they trace them down, a compellıng reflexivity emerges born out of the relation occurring between the designers and their drawings In their analogic procedures they follow the Vitruvian precept that indicates construction as 'a continuous and meditative process completed by the hands, Their thoughts engage a separate temporality from the flux of the cosmos by which effects occur indiscernibly before or after their causes ${ }^{6}$

7) Drawıngs make use of a particular sensory conjunction - that between feelıng and seeıng By both lookıng at and feelıng a surface of a drawing, designers are in contact respectively with both the outward appearance and finish of an edifice, and also the interior inauguration and solidity of construction The chıasm among the senses makes the designer aware of the complex interplay between the inside and the outside it thereby provides a new locus of architectural invention, since to draw is to enter into participation with both the inscriptions and the scribing that mark the surface of a drawing ?

8) Today the growing obsession with productivity and rationalization has transformed the process of maturation from the idea to the built work into a systematic representation that leaves little place for the invisible to emerge from the process of translation Computer graphics, with its seductive manipulation of viewpoints and delusions of three-dimensionality, are mostly a more sophisticated 'mechanism of composition' 8

9) Computer graphics tend to be just a much quicker and more facile tool that relies on mathematical projection, a basıc tool of in dustrial production The tyranny of computer graphics is even more systematic than any other tool of representation in its rigorous establıshment of a homogeneous space and its inability to combine different structures of reference ${ }^{9}$

10) This emerging 'architecture of resistance', celebrates dreams and the Imagination without forgetting that it is made for the Other, and aıms at revealıng depth not as homologous to breadth and height (3D), but as a significant first dimension that remaıns mysterious and remınds us of our lumınous opacity as mortals in a wondrous more-than-human world 10

11) 'the model-gaze reduces the possibilities of innovation' and 'stfles the pursuit of the absent referent beyond the present model' After all, one would argue that the workıngs of imagınation, which are at play in visual perception and in the contemplative as well as discernıng intellection, are not readıly constrained by what is visually given through modes of architectural representation ${ }^{11}$ 


\title{
$5.0-$ COSMOPOIESIS
}

\author{
5.1 - From MOdels to DRawings - Editors: Marco frascari, Jonathan hale \& Bradley Starkey
}

1) Architects are bound to treat as real that which exists only in an imagined future, and to specify the ways in which the foreseen things can be made to exist. In doing so they must predict the future nature of an artfact and that it will work as expected. In other words, the drawing process is a cosmopoiesis that can help to invent better futures and make potential worlds. A set of architectural drawings always corresponds to an infinite set of bult possibilities. ${ }^{1}$

2) Cosmopoiesıs, or world makıng, 'always starts from a world already at hand; the makıng is remaking.'2

3) By tracıng drawings, architects perform an act of world-makıng: a cosmographic expression that is also the root to future cosmopoiesıs. $^{3}$

$$
5.2 \text { - PRACTICE: ARCHITECIURE IECHNIQUE + REPRESENTATION - AUTHOR: STAN ALLEN }
$$

4) These revolutionary artists of the early twentieth century wanted to go beyond art's traditional role of interpreting the world to Imagine an art capable of constructing new worlds. Hence the attraction of axonometric projection. Axonometric, because it could transmit abstract information, and because it was measurable and precise, was the ideal tool to delineate the avant-garde vision of a new world. Perspective records what already exısts, whereas axonometric constructs that which does not yet exist. ${ }^{4}$

5) Through his [El Lissitzky] Prouns, utopian models for a new and better world were developed. This approach, in which the artist creates art with socially defined purpose, could aptly be summarized with his edict "das zielbewußte Schaffen" - "task oriented creation." 5

\section{3 - IHE DIAgrams of ARCHItecture - Editor: Mark Garcia}

6) The diagram does not belong to a logic of representation, like the other signs, but inaugurates a logic of sensation aimed at bringıng forward new worlds. The diagram allows the emergence of another possible world. ${ }^{6}$

7) "a set of architectural drawings always corresponds to an infinıte set of bult possibilities"?

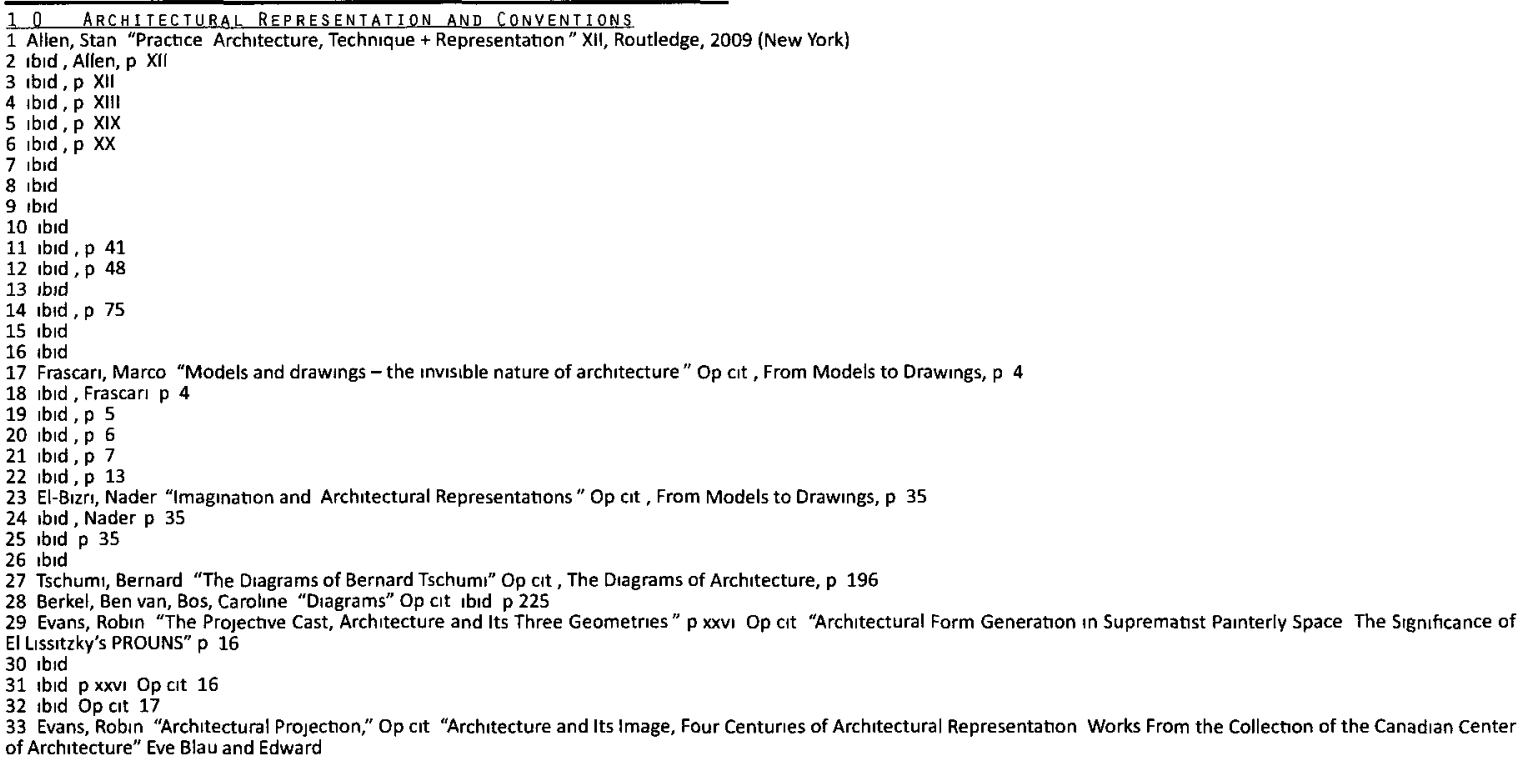




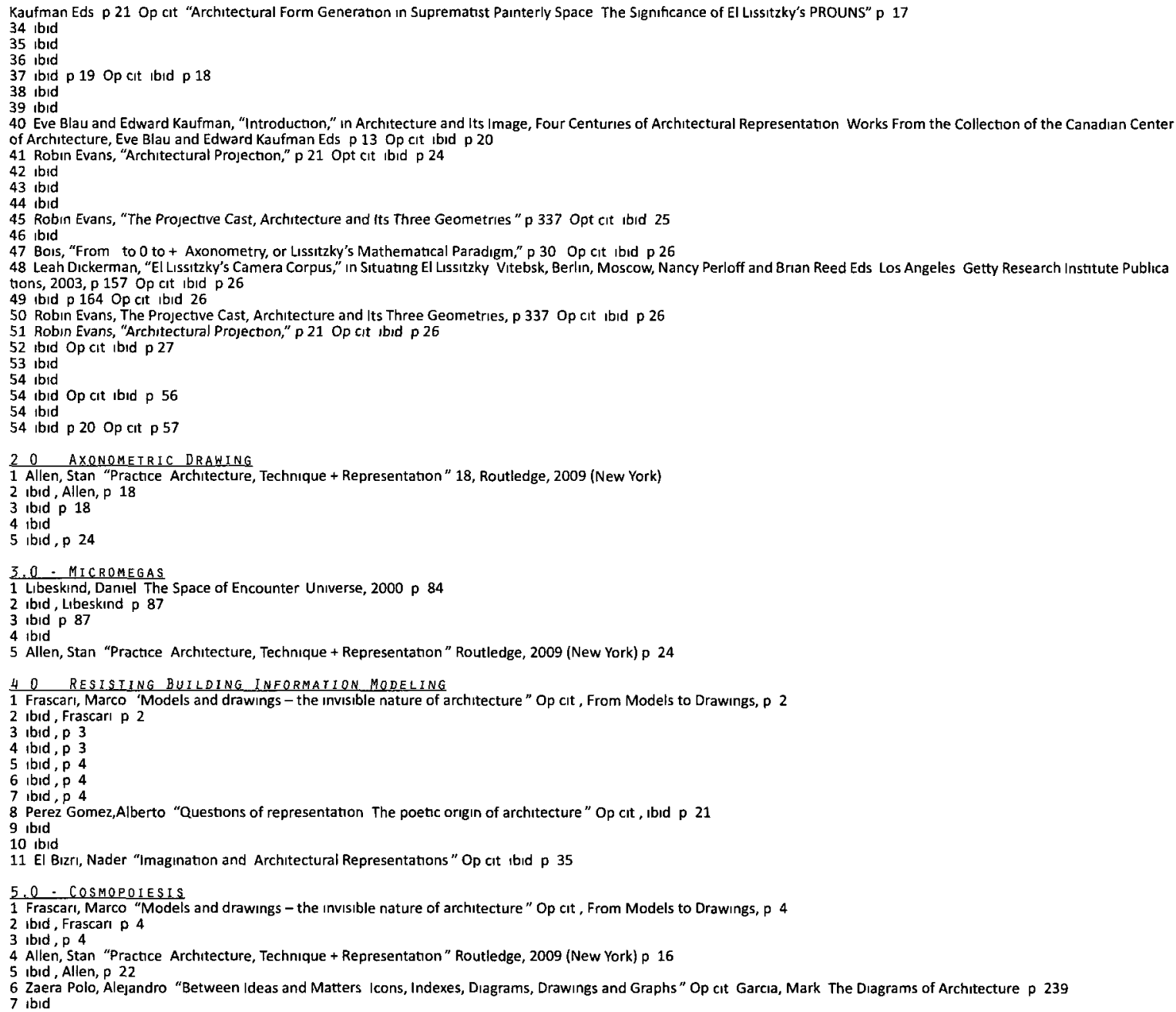




\title{
APPENDIX B :
}

\section{WORKS FROM EL LISSITZKY \& JOSEF ALBERS}

\author{
1.0 - EL LISSITZKY'S PROUNS
}

\section{ARCHITECTURAL FOrM GENERATION IN SUPREMAIIST PAINTERLy SPACE Author Kemal ReHa Kavas}

1) Alan C Birnholz argues that, sımılar to Klutsıs' work, most of the PROUNs presented "an architectonıc ıdea, such as a bridge or a cIty," but without any "concern of concrete architectural plans" 1 Similarly Yves Alain BoIs states that Lissitzky's success concerning the PROUNs was "being able to sustain a radical suspension of alternatives, to destabilize the spectator's spatial assumptions, without replacing them with ready-made solutions" 2 Emphasizing the same point, Birnholz claims that the PROUNs may be regarded as exercises for "the floating complex of spatial forms" implyıng architectonic ideas rather than proposals for particular programs or sites ${ }^{3}$

2) PROUN 1-E (1919-20) (Figure-11) enables a more explıcit suggestion of architectural forms, asserting "a more concrete architectonic Idea proposıng a Suprematist-town, a Suprematist system for a town square" by presenting the spatial arrangement In bird's eye view 4

3) For Evans, in contrast to the perspectival, the orthographic projection had traditionally been "the preponderant method for devisıng, pıcturıng, and transmitting ideas of buildıngs before they are bult" 5

4) However, Robın Evans thınks that the works of Doesburg and Lissitzky are indicative of a unique contribution to the use of the axonometric To Illustrate this quality Evans refers to Yves-Alaın Boıs who considers Doesburg and Lissitzky's axonometrics as "the first attempts to use this kind of projection in the service of aesthetic aıms rather than practical ones" 6

5) Evans claıms that the axonometrics provided Lissitzky with the possibility of Introducing "a change of sensıbılity by exploiting a visual ambiguity that causes the viewer to lose his bearıngs" 7 It is inferable from the argument of Evans that axonometric projection contributed to the conveying of the Suprematist sense of weightlessness or floating through challenging the viewer by superseding "the more familiar" perspectival projection in which, habitually, the viewer "knows his place" 8

6) Evans argues that this "active form generation" was triggered by the imagınative capabilities of the architect and the observer along with the potentrals inherent in the orthographic projection itself ${ }^{9}$

7) Although in the PROUNs, Lizzitsky assigned certain materials into the abstract surfaces through his special use of colour, he generally applıed this with an awareness that "new materials could be developed to approxımate the effect of the PROUNs in actual buildıngs" 10 Hence, it is possible to claim that the PROUNs maintain abstraction by preventing the complete disengagement from the specific conditions withın which architecture is obliged to act 11

8) L D Henderson argues that in contrast to Malevich's Suprematism, LIssitzky's PROUNs are indicative of an affinity with "a new expression of space" with a "transitory nature" 12 Henderson notes that Lissitzky used the term "Imaginary space" and explained it as follows "so temporal that it would exıst only as long as the object was in motion" 13

9) Every form is the petrifed snapshot of a process Therefore, work is a station in evolution and not its petrified aim ${ }^{14}$

10) Alan C Birnholz claıms that the experience of movement suggested likewise in the PROUNs "occurs wholly inside the spectator's mınd," strengthenıng Lissıtzky's proposal of the transformation of spectator's role "from passıvity to particıpation" 15

11) Birnholz's emphasis for the active role of the spectator may be related with Robın Evans' assertion of the creative imagination of the spectator as well as that of the architect as the prerequisite for the achievement of architectural representation ${ }^{16}$ As already mentioned, Robın Evans suggests two principle possible roles for architectural projections that "relates pictures to thıngs" either "to record or propagate thıngs already made" or "to project thıngs as yet unmade" 17

12) The surface of the PROUN ceases to be a picture and turns into a structure round which we must circle, lookıng at it from all sides, peerıng down from above, investigating from below Circling around it, we screw ourselves into the space We have set the PROUN in 
motion 18

13) It can be inferred that the use of color and three dimensıonal Illusions in the two dimensional surface of PROUNs aıms to "convey qualsties of abstraction or materialıty to our perceptions" as claımed by Lodder 19

14) The PROUN approach of El Lissitzky, therefore, offers an alternative view of "constructivism" contrasting with the mainstream Constructivist view that sees in the drawing no potential beyond the two-dimensional projection of the design object already conceptualized in physıcal space according to technical concerns 20

15) It makes a point of underlınıng Lissıtzky's deployment of the kınd of subjective ambıguity we touched on earlier in connection with 'geometrical ıllusıons', the varıous kınds of perceptual confusıon that can be evoked by relatively sımple 'geometric' figures ${ }^{21}$

16) Henderson's claim that, 'Often, Impossible overlappings and intersections, as well as the tendency of forms to fluctuate back and forth, suggest that only a higher dimensıonal space could encompass such contradıctions,' 22

17) Boıs suggests that axonometry 'abolishes perspective' and renders infinity 'thınkable by placıng the centre of geometrıc projection into infinity'You will recall that the notion of a centre of projection at infinity first appeared as a means of reconciling perspective and orthography, but that would not be so clear if you based your interpretation, as Boss seems to do, on LIssitzky's explanation of Suprematist space in 'A and Pangeometry', the text Bois regards as the 'official "birth certificate" of axonometry' ${ }^{23}$

18) Thus Bois is able to attribute the spatial ambiguities which can occur when a drawing lacks sufficient contextual pointers the ambiguites which are, of course, a promınent feature of the Prouns directly to axonometry He notes, 'The protension/retension or plus/minus effect of axonometry is intensified in almost all of the Prouns,' and remarks in a footnote, 'Josef Albers's Structural Constellations_a kınd of abstract versıon of the famous duck-rabbit figure_are the mechanical exploitations of this seesaw property inherent in axonometry'24

19) Havıng convinced hımself or having allowed Lissitzky to convince hım that what he calls 'radıcal reversıbılity' (In other words, the Necker cube effect) is somehow essentral to axonometry understood as a paradigm, Bois can speak of the 'magic of axonometry's fundamental ambıguity' The magıc, I thınk, comes from the investment of a subjective ambiguity with the (Implıcitly objective) indexicality associated with primary geometry, that is, projection This is the magıc which enables Bois to pull the rabbit out of the hat for his own time, as it had enabled Lissitzky before hım Bois's version is adjusted to a mılder political clımate III On Structure and Representation epıstemologıcal wish-Images and an intellectual milieu more tolerant of ambiguity and more accustomed to formalıstic allegories 25

20) Lissitzky considered his Prouns documents because they were, for hım, blueprints for action, charts for a strategy to be adopted in order to transform society This may appear to contradıct the theory that the Prouns intensify perceptive ambiguity, but I do not thınk this is the case they must be considered as abstract models of radical freedom and, as such their task on the ideological and theoretical levels is to fight against dogmatism and catharsıs, on the pıctorial level, this task becomes the deconstruction of perceptive Illusıons 26

21) Milka Blıznakov argues that El Lissıtzky achıeved to establısh a new system of spatial representation which responded to the inevitable needs of architectural realm such as materiality, applicability and stability 27

22) the PROUNs to acquire the capabulity of suggesting architectural representation by the introduction of three-dımensıonal Illusion ${ }^{28}$

23) PROUNs may be regarded as preparatory experıments that arose due to "the need for a certain degree of documentality even in abstraction" in order to "transcend the confinements dictated by the uncompromising strictures of Modernism" 29

24) LIssitzky represented an alternative interpretation of constructivism different from the mainstream lıne ${ }^{30}$

25) LIssitzky's PROUNs may be consıdered as a starting point for a further attempt to reintroduce individual artistic skıll and craftsmanship into the form generative process of architecture, which had been saturated by technical constraints of mechanization and collectivity ${ }^{31}$

26) "and I [EI LISSItzky] created the PROUN as an intermediary station on the road between painting and architecture I have treated canvas and wood panel as a building site which placed the fewest restrictions on my constructional ideas" 32 
27) Through the definition of the PROUN, El Lissitzky had expressed his profound understanding of the multidımensıonality of architectural production, which would otherwise be conceived withın the narrow limitations of traditional understandıng ${ }^{33}$

28) Robın Evans emphasizes the "Imaginative roles" of both the architect and the observer to argue that the communicative function of the drawing is modified by both of them ${ }^{34}$

29) This is the drawing's form generative quality achieved through the interaction of the producer's and the spectator's imaginative capacities 35

30) PROUNs constitute "inter-changeable situation between painting and architecture" 3648 that inevitably necessitate a three-dımensional mental construction through illusion 37

31) It should be noted that the mentioned Illusionary quality of the PROUNs is in conformity with the principal Ideas of Malevich, such as the emphasis on the role of human mind as the principle source of spatial intuition and the idea of liberation from gravity ${ }^{38}$

\section{Practice. Architecture technique + Representation Author Stan Allen}

32) These revolutionary artists of the early twentieth century wanted to go beyond art's traditional role of interpreting the world to Imagine an art capable of constructing new worlds Hence the attraction of axonometric projection Axonometric, because it could transmit abstract information, and because it was measurable and precise, was the ideal tool to delıneate the avant-garde visıon of a new world Perspective records what already exists, whereas axonometric constructs that which does not yet exist ${ }^{27}$

33) "Perspective," Lissitzky writes, "Iımits space, it has made it finite, closed" The world is put into a cubic box, which creates a static "façade view" of the world Suprematism, on the other hand, "has extended the apex of the finite visual cone of perspective into Infinity it has broken through the blue lampshade of the heavens" In Lissitzky's "Irrational" space, viewpoint and vanishıng point are both located at infinity The infinite extension in depth coincides with the suspension of the subject's privileges of self-location The viewing subject and the object of representation both inhabit the same extended field Projection operates to simultaneously extend and collapse distance "Suprematist space can be formed in front of the surface as well as in depth [ ] Suprematism has swept away the Illusion of three-dımentional space on a plane, replacing it with the ultimate Illusion of irrational space with attributes of Infinite extensibility in depth and foreground "28

34) By extending the vanıshıng point to infinity, the constructions of perspective are rendered at one and the same time more flexıble from an instrumental point of view, and more universal from a philosophic point of view ${ }^{29}$

35) It was not only infinite space that was made visible in axonometric projection, but also new concepts of time if perspective, dependent on a fixed point of view, seemed to freeze time and motion, the atypical space of axonometric suggested a continuous space in which elements are in constant motion ${ }^{30}$

36) could be exploited here to suggest the sımultaneity of space and time The reversıbılity of the spatal field allowed for the sımultaneous presentation of multiple views ${ }^{31}$

37) Distanced from the viewer (who, in axonometric projection is usually located not in front of, but above or below the object), the represented object can be freely rotated, dismantled or reconstructed Axonometric and technical drawings lend themselves to the multiplication of views in an effort to describe the complex totality of the object 32

38) They were fascınated by the reversıbılıty of the spatial field in axonometrıc, which seemed to render space extensive Axonometric projection was an ideal device to represent universal geometries and infinite space These artists suggested by implication that axonometric, although originally derived from the technical disciplınes, may sımultaneously map a new condition of vision - a modern condition of vision marked by the fundamental abstractness of technology and the universal geometries of mathematics ${ }^{33}$

39) If we compare the implied space of the proun drawings with the 1923 proun space, it becomes evident that the infinite extension of the visual field is more present as representation than as experience ${ }^{34}$ 
40) The proun space is still a representation device, a construction suggesting something beyond itself 35

41) The classıcal symbolısm of measurable figurative space is exchanged for a new symbolısm of infinıte abstract space ${ }^{36}$

42) The double metaphysics of early modernısm - infinite space and sımultaneous time available only as a metaphor 37

43) El Lissitzky defined them ambiguously as "the station where one changes from painting to architecture "38

44) Prouns was essentially El Lissitzky's exploration of the visual language of suprematısm with spatial elements, utiızıng shıftıng axes and multiple perspectives, both uncommon ideas in suprematism Suprematism at the time was conducted almost exclusively in flat, 2D forms and shapes, and El Lissitzky, with a taste for architecture and other 3D concepts, tried to expand suprematism beyond this ${ }^{39}$

45) Through his Prouns, utopian models for a new and better world were developed This approach, in which the artist creates art with socially defined purpose, could aptly be summarized with his edict "das zielbewußte Schaffen" - "task oriented creation "40

\section{ARCHITECTURAL MODEL AS MACHINE - AUTHOR A C SMITH}

46) Interconnecting forms distorted the regularity of shapes, creating a feelıng of movement Different shapes, scales, and textures enhanced these dynamic tensions Prouns deployed a space that tended to reach out in front of the picture plan, as opposed to the infinity behınd it ${ }^{41}$

47) The resulting ımage is not a painting but a structure around which we must cırcle, lookıng at it from all sides, peerıng down from above, investigating from below We screw ourselves into the space Proun does not serve any particular goes, as it has the power to create such goals (and, Indeed, the power to create new materials by creating the new forms which demand them) It transcends both the engineer and the traditional artist, somehow superseding the individual producer of architecture through the introduction of the principle of collective creativity 42

48) Lissitzky realized that a smooth transition from the imaginary space of the prouns to the real space of architecture was very difficult ${ }^{43}$

\section{0 - JOSEF Albers' 'Structural CONStellations'}

1) Structural Constellations originate in the sphere of drawıng and make their appearance on the stage of art They are bound to the tradition of which we have explored a few epısodes in this essay even if perhaps, in truth, more intimately because, they seem to highlight the paradoxes of that tradition The contrarıness of Structural Constellations relies on the artist's ability to predict certain types of reaction to his work Albers's work, I would argue, is less concerned with transmitting a message than it is with preparıng a rendez-vous with the viewer Hence the importance of the appearance of the work, not just in the sense of what it looks like, but in the sense of the time and place it shows up, perhaps to ambush the viewer's expectations The immediately captivating aspect of Structural Constellathons, despite the resolute flatness of their construction (emphasized in the engravings and intaglios by the engagement with the material surface), is the compellıng suggestion of three-dimensıonal figures and relationships On inspection, however, the Images which appear from Albers's constructions seem to contain contradictions and ambiguities It is as if Albers has arranged a clash of the 'elther-or' that Necker first remarked in a puzzlıng 'both-and' An aspect which is not quite so obvious, even as one puzzles over what a Structural Constellation could be a drawing of, is the 'both-and' in which abstraction and representation are twisted round one another ${ }^{1}$

2) Somewhat overawed by Albers's abstraction, Finkelsteın insısts, regardıng Structural Constellations, 'Albers has completely freed the structures to assert their own reality, independent of any reference, intellectual or emotional, to any other reality,' moreover, that Albers has 'disınherited the traditional conventions for reconstructing the visıble, three-dimensional world of our experience and has replaced them with the creation of a dynamic and self contained world in which the elements form and space, or object and environment, or positive and negative, or material and ımmaterıal, no longer have meaning by traditional definition, in fact, it has become increasingly difficult, if not impossible, to distinguish these elements or concepts from each other' This 'other world', of course, is 
Finkelsteın's own creation in which he has hypostatized his embarrassment as an absolute impossıbility, which he tries to dignıfy as the 'meanıng and essence' of the works 2

3) Françoıs Bucher's opınıon ıs typıcal and possıbly ınfluenced subsequent commentators These experıments [ı Structural Constellations] are probably [Albers's] most important and as yet least developed discovery They elegantly begin an honest visual exploration of the little known characterıstics of non-Euclıdean dımensıons. ${ }^{3}$

4) Benezra's almost Ironic comment, 'Albers' non-Euclıdean geometry postulates a sphere of the imagınation where such relations are possible'4

5) Structural Constellations seem to present us with a mıse en abîme of all the problematics of geometry and meanıng we have dıscussed so far An analysis could easily prompt an inventory of the ambiguities, aporias and slippages with which geometry leaves us in the field of representation Albers seems to make use of geometry for all the expectations it can arouse as a kınd of lure 5

6) I prefer to show some straight lınes, un-modulated and two-dımensional, which through their constellations challenge our reading of them, and with this, our Imagination As we regard these, their directions constantly change We perform perceptual effects by addıng and seeıng spatial qualities and motion, both of which do not exist factually, but only in our producing and seeing them 6

7) In Aibers's work the promise becomes a lure because it was always so Geometry, conjured by no more than straight-edge drawing was the sign by which modern art (If we trace this back to Albert) staked its claims both to representation and to higher truth But why did it become a lure when Albers made it so? Because Albers insists that what you see is what you get Except that seeing is probably more than you bargained for Albers makes a point of the phenomena (Indeed, the phenomenology) of seeıng, about whıch the proponents of Suprematism or Neo-plasticısm as much as of perspective itself were anxious to keep quiet in order to preserve their authority as artists. ${ }^{7}$

8) Albers's works implicate a you (that is, the viewing subject") at the expense of an I (that is, the first person of the artist-creator) The work is autonomous, not in the sense inherited from l'art pour l'art, or because it has somehow escaped the contingency of its material form, but because the author has withdrawn from the work We might call it an intentionless work. ${ }^{8}$

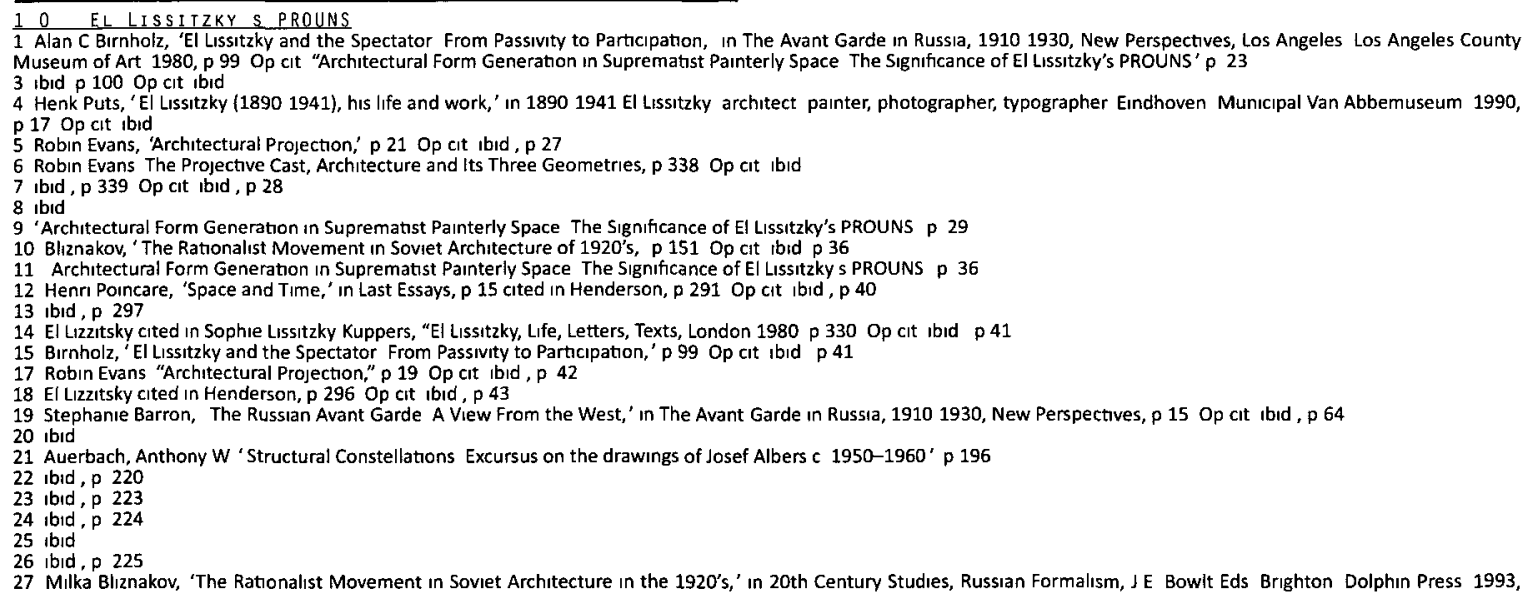


pp 150151 Op cit "Architectural Form Generation in Supremanst Painterly Space The Significance of El LISSItzky's PROUNS" p 5 28 "Architectural Form Generation in Suprematist Painterly Space The Significance of El Lissitzky's PROUNS" p 7

29 Lodder, Russian Constructivism, pp 180-188 Op cit ibid p 8

30 Bowlt, "Manipulating Metaphors El Lissitzky and the Crafted Hand," pp 133-148 Op cit ibld , p

31 "Architectural Form Generation in Suprematist Painterly Space The Significance of El LIssitzky's PROUNS" p 15

32 El Lissitzky cited in Sophie Lissitzky Kuppers, El Lissitzky, London, 1980, p 325 Op cit ibid, $p$ 15

33 Architectural Form Generation in Suprematist Painterly Space The Significance of El Lissitzky's PROUNS" p 16

34 ibid, p 20

35 ibid

36 Lissitzky cited in Lodder, Russıan Constructivism, p 183 Op cit ।bid, $p 22$

Architectural Form Generaton in Suprematst Painterly Space The Significance of El LIssitzky's PROUNS" p 22

38 Bliznakov, "The Rationalist Movement in Soviet Architecture in the 1920's," p 150 Op cit ibid , p 22

99 Allen, Stan "Practice Architecture, Technıque + Representation" p 16

40 ibid, Allen, p 16

41 ibid pg 16

42 tbid $p$

43 ibid

44 ibid

46 ibid, p 22

47 ibid

48 ibid

49 ibid

50 ibid

51 ibid

53 Smith, Albert C Architectural Model as Machıne p 103

54 ibid, Smith p 105

55 ibid $p 106$

20 JOSEF ALBERS' STRUCTURAL CONSTELLATIONS

1 Auerbach, Anthony W "Structural Constellations Excursus on the drawings of Josef Albers c 1950-1960" p 206

$\begin{array}{lll}2 & \text { ibid, p } 207 \\ 3 & \text { ibid, p } 209\end{array}$

4 ibid

5 ibid p 210

6 ibid p 213

7 ibid p 214

8 ibid 


\section{APPENDIX C:}

\section{PERCEPTION, THE DRAWING GAZE \& IMAGINATION}

\section{$1.0-$ PERCEPTION}

\section{ARCHItectural MOdel as Machine Author a C SMITH}

1)If one plays with an Illusion, its falsehood may become apparent Albert appears to be recommending allusion in the small-scale model "Allusion" means figurative or symbolic reference, or 'to allude' may also mean to play with This differs from 'illusion' which is an erroneous interpretation that can be agaınst play Albert is makıng the case that we should play with our small-scale models, through the projection of our ideas 1

2) "An Illusion can create a deceptive appearance of an object through false belief" 2

3) The architectural scale model helps the architect to create allusion and can be used to destroy illusion Stage sets, trompe l'oeils and certain types of architectural drawings all have the ability to deceive the viewer by presenting a false impression of reality because they are viewed from only one position The allusion of the design scale model can permit the development of analogy and interpretation 3

\section{OPTICAL ILLUSIONS - CREATOR RAMONA WINKLER}

4) Perception is the process by which organisms interpret and organize sensation to produce a meanıngful experience of the world Sensation usually refers to the immediate, relatively unprocessed result of stimulation of sensory receptors in the eyes, ears, nose, tongue, or skın Perception, on the other hand, better describes one's ultmate experience of the world and typically involves further processing of sensory input in practice, sensation and perception are virtually impossible to separate, because they are part of one continuous process 4

5) Organızıng raw sensory stimulı into meanıngful experıences ınvolves cognition, a set of mental activities that includes thınkıng, knowing, and remembering Knowledge and experience are extremely important to perception, because they help us make sense of the input to our sensory systems 5

6) What is noteworthy is stability in perception despite gross instability in stimulation Such matches between the object as it is perceived and the object as it is understood to actually exist (regardless of transformations in the energy of stimulation) are called perceptual constancies Dimensions of visual experience that exhibit constancy include size, shape, brightness, and colour ${ }^{6}$

7) Perceptual constancy denotes the tendency of animals and humans to see familiar objects as having standard shape, size, colour, or location regardless of changes in the angle of perspective, distance, or lighting The impression tends to conform to the object as it is or is assumed to be, rather than to the actual stimulus Perceptual constancy is responsible for the ability to identify objects under various conditions, which seem to be "taken into account" during a process of mental reconstitution of the known image?

8) Perceptual constancy tends to prevall for these dimensions as long as the observer has appropriate contextual cues, for example, perception of sıze constancy depends on cues that allow one a valıd assessment of his distance from the object With distance accurately perceived, the apparent size of an object tends to remain remarkably stable, especially for highly familiar objects that have a standard size 8

9) Not only does perception involve organization and groupıng, it also involves distinguishing an object from its surroundıngs Notice that once you perceive an object, the area around that object becomes the background 9

10) The "figure and ground" Illusion is commonly experienced when one gazes at the Illustration of a black vase the outlıne of which is created by two white profiles 10

11) The fluctuations of figure and ground may occur even when one falls delıberately to shift attention, appearıng without conscious effort SeeIng one aspect apparently excludes seeing the other ${ }^{11}$ 
12) In other words, the perceiver is said to be perceptually adapted to past sensory stimuli, his adaptation level forms a kınd of zero point against which any new stimulus is perceived 22

13) First, people learn the general sıze of objects through experience and use thıs knowledge to help judge size ${ }^{13}$

14) Thus, the apparent brightness of a stımulus depends not only on its own lumınance but also on that of the surroundıng stımulatron ${ }^{14}$

15) Depth perception is the abılity to see the world in three dımensions and to perceive distance ${ }^{15}$

16) Interposition Probably the most important monocular cue is interposition, or overlap When one object overlaps or partly blocks our view of another object, we judge the covered object as being farther away from us 16

17) Texture Gradient A texture gradient arıses whenever we view a surface from a slant, rather than directly from above The texture becomes denser and less detailed as the surface recedes into the background, and this information helps us to Judge depth 17

\section{8) Linear perspective The more the lines converge, the farther away they appear ${ }^{18}$}

19) Size Cues Another visual cue to apparent depth is closely related to size constancy if we assume that two objects are the same size, we perceive the object that casts a smaller retinal ımage as farther away than the object that casts a larger retnal Image This depth cue is known as relative sıze, because we consider the size of an object's retnal Image relative to other objects when estimating its distance Another depth cue involves the familiar size of objects Through experience, we become familiar with the standard size of certain objects Knowing the size of these objects helps us judge our distance from them and from objects around them 19

20) Height Cues We perceive points nearer to the horizon as more distant than points that are farther away from the horizon called relative height, because when judgıng an object's distance, we consıder its height in our visual field relative to other objects 20

21) These observations concern circumstances in which people perceive movement in the absence of actual physıcal motion of the stimulus 21

22) People may perceive motion when none actually exists 22

\section{IHe Diagrams of ARCHITECTURE - Editor MARK Garcia}

23) The Kaplan's belıeve that the perception is strongly influences by prior experience, that preference factors include contents and organization, and that variations in the preference are the result of cultural and ethnic patterns, as well as personal experience ${ }^{23}$

24) Thus our perceptual systems are influences by both prior experience as manifested in memory, and preference factors as they affect the perception of the contents of our milieu ${ }^{24}$

25) Charles W Rusch suggest that awareness may have developed from the human need to reduce the sheer amount of information in the environment for survival This entailed the 'filterıng out' of less immediately vital material, and the concomitant 'structurıng' of the remaınder, I e giving it meanıng Such 'recodıng' of Information is used to symbolize a large amount of detaled data, and leads to the ongoing process known as reflection 25

26) As we record only those stımulı that have a bearıng on particular needs, perceptions may differ 'The perceptions of two individuals vary as a function of differences in the content of the information presented and the differences in the abılity of individuals to pick up the information messages 26 


\section{0 - DRAWING GAZE}

\section{ARCHITECTURAL FORM GENERATION IN SUPREMATIST PAINTERLY SPACE AUTHOR KEMAL REHA KAVAS}

1) Evans claıms that the removal of the "activating imagınation" from the reading of the architectural projection might lead to its appreciation as "a mere technical facilitator" which ımpicitly accept that "drawing can propagate things but never generate them" 1

2) Robın Evans claıms that the imagınation of the observer plays a crucıal role for the "mobilization of the projected information" concernıng the accomplishment of architectural representation - the creative "embodıment" thus "projection" of the architectural object that is "yet unmade" 2

\section{2 the space of encounter Author daniel Libeskind}

3) Most of all, however, I am a fascinated observer and a perplexed participant of that mysterious desire which seeks a radical elucidation of the origınal pre-comprehension of forms - an ambition which I thınk is implicit in all architecture ${ }^{3}$

4) These drawings seek to reflect, on a deeper level of consciousness, the inner life of geometrical order whose nucleus is the conflict between the voluntary and the involuntary Once again thıs appears as an under passable condition pointing to a dynamic ground which testifies to an experience receiving only as much as it is capable of giving, draws only that which allows itself to be drawn into 4

\section{3 - ARChitectural MOdel as Machine Author a C SMith}

5) When the architect is exposed to chaos there is a stiring up of the unconscious psyche, which produces fantasies, hallucinations, and visions However, for all its horror and confusion, the experience of chaos is seen by architects as a positive experience, since it allows relationships to be seen in new and unusual ways 5

\section{4 - IHE DIAGRAMS OF ARCHITECTURE EDITOR MARK GARCIA}

6) Kant - the world of experience divided into a 'material' and a 'formal' component Material referred to sense-qualities found on the side of the object, the world, or, in the Kantian Jargon, of the 'manıfold' The formal domain, that which we are interested in when we want to understand the diagram, belongs on the side of the perceiving mind or agent, it refers to an a priorı organızation The formal, however, appears on the side of the subjective, it corresponds to the a priorı schema which on its own is hollow, and must be filled in with data acquired from outside through the senses 6

\section{$3.0-$ IMAGINATION \\ 31 From MOdels to Drawings editors marco frascari jonathan hale \& bradley starkey}

1) Seeing here surfaces of an opaque cube in immediate vision is sufficient to judge that what is seen is a 'cube' Even though its other three sides are not visible The wholeness of the cube as a geometric solid formed of six planar un-curved surfaces cannot be offered to vision in its entrety unless the cube is fully transparent However, each of these surfaces can be visually inspected and varies by rotating the cube in space or moving around it The cube is revealed in its visible aspects in the successive unfolding of its manifold ap pearances through movement in space-time Seeıng three surfaces of the cube as skewed and sharp-edged planes extended in depth, and identifyıng them as such as being three square-surfaces associable with a cubic geometric solid, is sufficient to judge with prior knowledge that this configuration of planes is a 'cube' This phenomenon is founded on an experimental trust in the structure of what is seen, along with the perceptual confidence that what appears in parts is the whole that remains invisible in its plenitude The fullness of the cube is this revealed through 'authentic' visible aspects that are perceived in immediate direct vision and in presence along with Imagıned supplements that are taken in trust to be the concealed 'potentrally visible' aspects of that cube, which structurally complete its formal fuliness This phenomenon points to the perception of a unified objective structural identity withın a stream of manıfold appearances Each visible aspect of an object is dependent of the structural whole of which it is a park ${ }^{2}$

2) Imagınation as a faculty that furnıshes the a priorı grounds of the possıbility of subjective experiencing synthesizing the manifold of sensory impressions into the form of a unified Image' hence rendering our knowledge of the phenomenal work possible, as well as recollecting appearances into representations that underlie the concepts of 'understandıng' 2

3) Imagination secures a ground for the discernment and comparative measure of the eidetic quiddity of a given object of visual per- 
ception Perceiving a thing in parts, and by way of the unfoldıng of a continuum of its manifold visible aspects, engages the imagination in revealıng the structural fullness of the form or that thıng, even if the thıng is invisible in its wholeness The formal plenitude of an object of vision supplements the immediately visible facets of this object with 'potentral perceivable' imagined aspects that may become unconcealed in actuality ${ }^{3}$

4) Drawing as a leakıng barrier is defective and fragmentary In an attempt to trace the 'successive displacement of thought', drawing 'always says something less with respect to the sum of what can be experienced' The lines 'point at something more And we are always searching for something hidden, or merely potentral, following its traces whether they appear on the surface ${ }^{4}$

5) Without undermınıng the importance of precisıon - the plan, the section, the detall, all drawn with exactitude - without denyıng that at the later stages of design one is held accountable for every line made, it is important to learn to trust in the unfoldıng of the idea, to be receptive to the growth of the image, to allow the drawing to lead, but at the same time be able to select, discard or further build upon uncovered possibilities ${ }^{5}$

6) Imagination secures a ground for the discernment and comparative measure of the eidetic quiddity of a given object of visual perception (namely what classical scholars desıgnated also as beıng a 'forma universalıs') Perceiving a thing in parts, and by way of the unfoldıng of a continuum of its manifold visıble aspects, engages the imagination in revealıng the structural fullness of the form and that thıng, even if the thing is invisible in its wholeness ${ }^{6}$

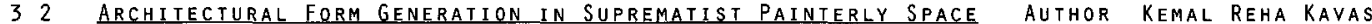

7) Evans asserts that the role of imagınation is so sıgnificant for achievıng architectural representation that the contribution of "the observer's imagınation is itself comparable to projection" envisioned by the architect ?

8) Evans argues that, based on the ımagınative faculty of the observer, archıtectural drawings have the potenthal to convey "a constant Interplay between the passive portrayal and active remodelıng of realıty" 8

1 Smith Albert C Architectural Model as Machine p 28

2 ibid $p 45$

422 Winkler Ramona Optical Illusions Ed Gerd Waloszek April 2006 November 2011 <http//www sapdesignguild org/resources/optcal_Illusions/optical_Ilusions pdf> 23 Malnar Joy Monice Vodvarka Frank Diagrams in Multisensory and Phenomenological Architecture Op cit Garcla Mark The Diagrams of Architecture $p 114$

24 ibid $p 115$

26 ibid p 117

20 DRAWING GAZE

1 Robin Evans Architectural Projection p 20 Op cit Architectural Form Generation in Suprematist Painterly Space The Significance of El Lissitzky s PROUNS p 21 2 ibıd p 21 Op cit ibid

3 Libeskind Daniel The Space of Encounter Universe 2000 p 87

4 ibid

5 Smith Albert $C$ Architectural Model as Machıne $p 114$

6 Kwinter Sanford The Hammer and the Song Op cit Garcia Mark The Diagrams of Architecture p 123

30 DRAWING GAZE

1 El Bizrr Nader Imagination and Architectural Representations Op cit From Models to Drawings p 39

2 ibid $\mathrm{p} 40$

3 ibıd

4 ibid

5 ibid

6 ibid $p 39$

Robin Evans Architectural Projection p 21 Op cit Architectural Form Generation In Suprematist Painterly Space The Significance of El Lissitzky s PROUNS p 20 8 ibid 


\title{
APPENDIX D:
}

\author{
ARCHITECTURAL SCALE MODELS \\ 1.0 - ARChitectural MOdel as Machine - Author: A.C. SMith
}

1) If the scale model machıne is over governed, it becomes sodden (lifeless) and may fall into the sea Conversely, there is the real possibility of being burned by the chaos created through an ungoverned technology By following a moderate mediating course Daedalus, the architect, reached his goal 1

2) Italo Calvino, who writes in Six memos for the next millennium, 'In order to escape the arbitrary nature of exıstence, Perec, like his protagonıst, is forced to impose rigorous rules and regulations on hımself, even if these rules are, in turn, arbitrary But, the miracle is that this system of poetics, which might seem artificial and mechanical, produces inexhaustible freedom and wealth of invention ' Architects today may be forced to impose sımılar standards upon themselves Some standards are necessary in order to coherently interpret the message of the scale models and to engage in the search for a definition of invisible things 2

3) The scale model is a mechanısm for creating definition, mediating between perceived chaos and human designs Positioned in the marginal area between lifelessness and the uncanny, the visible and the invisible, the architectural model appears to offer architects an understandable way with which to develop and define their concepts 3

4) They (arch Models) can be less ambıguous than drawings Accordıng to Stanford Hohauser, architectural models are the most easıly understood presentational technıque ${ }^{4}$

5) Scale allows the architect a means for clımbıng towards a definition, developıng a balance or medium between a known and an unknown, creating a standard with which to refer and a way of peelıng away to reveal that which is unseen 5

6) Architectural models are subjective The subjective model is one that is derived from the mind and not from external objective sources 6

7) A representation can be an ımage, likeness or reproduction in which some manner of a thing is presented to the mind or ımagınation ${ }^{7}$

8) The architectural scale model should be viewed as a mechanısm for creating definition, mediating between chaos and humanity's designs It is a mechanısm that helps architects develop an understandable scale with which to measure the unknown thing, such as a future bulding The architectural model machine should be consıdered a scale device, which helps extend an architect's intellectual might in an attempt to understand, define, and measure various issues 8

9) Sometimes however, the projection of thoughts on to the scale model machıne can make it appear to take on a life of its own This happens in the realm of our imagination 9

10) For Hume, the ımagınation was also a mediation between ıdeas of memory and judgment From Arıstotle to Kant, Imagınıng is seen as a mediatıng or middle-range power This is the area in which the scale model machıne dwells in this way the scale model is a machıne for ımagınıng, for developing the free associations needed to develop new ideas ${ }^{10}$

11) Also, consider that the scale model not only compels the architect to think about a future building, but also serves as a condurt for thınkıng about and creating definıtions 11

12) The architectural model is a thınkıng mechanısm used in makıng the invisıble visıble ${ }^{12}$

13) The maquette can warn the architect of future problems and can allow marvel, wonder, astonıshment, and surprise into the design process 13

14) The work sımulacrum comes from the Latn word sımılar whıch means to make lıke or to sımulate A sımulacrum is a representation, Image or effigy having merely the form or appearance of a certain thıng without possessing its substance or proper qualities it can be 
an Imıtation or sham which can create a superficial likeness, appearance or semblance ${ }^{14}$

15) Better than that the models are not accurately finıshed, refined, and highly decorated, but plaın and sımple, so that they demonstrate the ingenulty of hım who conceived the ıdea, and not the skill of the one who fabricated the model 15

16) If one plays with an illusion, its faisehood may become apparent Albert appears to be recommending allusion in the small-scale model "Allusion" means figurative or symbolic reference, or 'to allude' may also mean to play with This differs from 'illusion' which is an erroneous interpretation that can be agaınst play Albert is making the case that we should play with our small-scale models, through the projection of our ideas 16

17) Connection between the name Daedalus and the Greek word daıdala which means to make or manufacture 'Daidala' are therefore capable of creating dangerous Illusions Daidala, or art objects, can appear to be what they are not, and the metal plates give a value to the objects that they would not otherwise have The princıpal value of 'dıadala' is that of enablıng inanımate matter to become magically alive, of 'reproducing, life rather than 'representing' it ${ }^{17}$

18) An Illusion can create a deceptive appearance of an object through false belief ${ }^{18}$

19) The architectural scale model helps the architect to create allusion and can be used to destroy illusion Stage sets, trompe l'oeils and certain types of architectural drawings all have the abılity to deceive the viewer by presenting a false impression of reality because they are viewed from only one position The allusion of the design scale model can permit the development of analogy and interpretation When architects manıpulate their scale model mechanısms they play with their imaginations They can use the scale model to discover the unknown Allusions and analogies appear to architects through the mental projection of thoughts on to the framework offered by the machıne-like scale models It is through scale models that architects can develop the allusions and analogies used to participate in a broader search for true definition 19

20) If one accepts that an architectural scale model can serve as a representation of ınvisible things, then the scale model can be regarded as a form of icon An Icon is an Image, likeness or representation of somethıng It is a picture of a sign that is IIke an Image of the thıng it indıcates or represents 20

21) It is a mechanısm that helps architects develop an understandable scale with which to measure the unknown The architectural model machine is a scale device, which helps extend the architect's intellectual might in an attempt to understand, define, and measure ${ }^{21}$

22) The scale model provides architects a mechanısm with which they can test and re-examıne their ideas in this attempt ${ }^{22}$

23) Sometimes, however, the projection of thoughts makes the scale model machıne appear to take on a life of its own This life is a reflection of an individual's ımagınation The scale model is a machıne for ımagınıng, for developıng the free associations needed to develop new ideas 23

24) To be useful for architects, the free association reflected from the scale model machıne needs to be governed This governıng comes from the relationship of the architect with his or her reference standard if the reference standard governs too loosely, the message received from the scale model machıne will appear uncanny or overly spontaneous if the reference standard governs too much then the message reflected from the scale model machıne will be lifeless 24

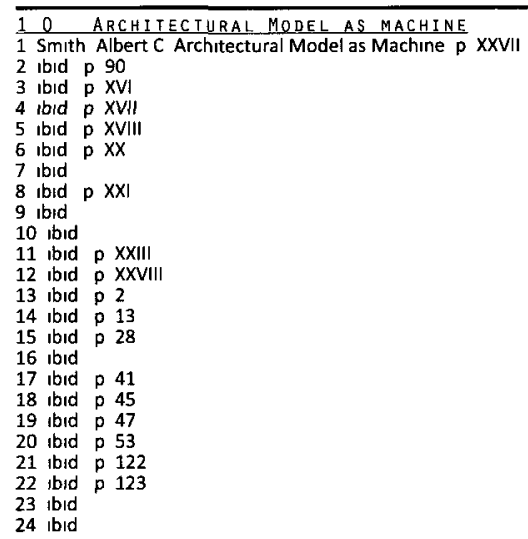




\title{
APPENDIX E:
}

\section{PETER EISENMAN'S HOUSE VI: DESIGN \& PROCESS}

\author{
$1.0-$ HOUSE VI \\ 11 - Peter eisenman S house Vi the Clients Response author suzanne frank
}

1) In house VI, a particular juxtaposition of solids and voids produces a situation that is only resolved by the mind's finding the need to change the position of the elements This mental attempt to reorder the elements is triggered by the precise size, shape, and juxtaposition of real walls, but is instead in our conception of their potentnal location The sense of warping, distortion, fluctuation, or articulathon occurs because of the mind's propensity to order or conceptualıze physical facts in certain ways - such as the need to complete a sequence $A-B$, or to read symmetries in a straight line about a fulcrum or along a diagonal Iıne in relation to a datum ${ }^{1}$

2) that is the end result of a process - but more accurately a record of a process The house, like the set of diagrammed transformations on which its design is based, is a series of film stills compressed in time and space Thus, the process itself becomes an object, but not an object as an aesthetic experience or as a series of iconic meanings Rather, it becomes an exploration into the range of potential manipulations latent in the nature of architecture, unavallable to our consciousness because they are obscured by cultural preconceptions ${ }^{2}$

3) Architecture is based on a dialectic between what is real and what is virtual Architecture is the synthesis or transcendent state that arises out of that dialectic This synthesis can only take place in the mind Design involves creating the necessary conditions of dialectic between virtual space and real space House $\mathrm{VI}$ proposes that dialectic ${ }^{3}$

\section{TRACING EISENMAN EDITOR CYNTHIA DAYIDSON}

4) Eisenman's architecture has been "process driven" That is to say, for Eisenman, architectural form is the outcome, or registration, of a series of design procedures These procedures are under the control of the architect, carried out by graphic means, and have their own internal logic That logic in turn is seen to be embedded in the architectural object as meaning and formal organization 4

5) For EIsenman, design is the inscription of meanıng into, or onto, the work by means of a series of more or less rigorous operations carries out by the designer Eisenman as an architect imparts meaning to the building, which is in turn registered by its increasing complexity This formal intricacy is intended to elicit a "decodıng" operation as the viewer is invited to unpack the process of the makıng of the object, much as the indexical sign elicits a reconstruction of causes from effects, or a detective reconstructs a coherent narrative of the crime from scattered clues 5

6) Thus the object not only is the end result of its own generative history but also retains this history, serving as a complete record of It, process and product beginnıng to become interchangeable ${ }^{6}$

7) Describıng house VI, Eisenman explaıned that "this work is an attempt to transcend our traditional view of desıgnıng, seeing, understanding our environment it is an attempt to alıenate the individual from the known way in which he perceives and understands his environment to an environment which presents itself through a logical structure of space spatial relationships that are both perceptual and conceptual Alienating the viewer from norms, expectations, and habits served as a wake-up call, a shockıng view into new spatial possibilities?

\section{3 - Iheoretical AnXiety and Design Strategies author Rafael Moneo}

8) Of course knowing this was most disturbıng, and Eısenman felt obliged to introduce the concept of 'process', the idea being that a project must be read in terms of the sequence in time that has made it possible On its own, the object doesn't reveal the architect's Intentions - or ideas, if you will For them to be perceptible, it is necessary to give evidence of process Representing the architecture is not a mere matter of definıng the object, but of takıng stock of the process behınd it And so we see how the ideal grid on which the architect is to work is activated by a first, formal impulse that gives rise to a series of transformations and inventions, and these are documented at every single phase of the work The process is made visible by documenting it Registering its different stages helps us understand the development of the formal operations dictated by the mind through time This is something that the object, which we only see in its final state, does not lend itself to EIsenman's desire to put on record what he calls the 'ideas' that generated the 
architecture makes hım confuse them with the process Only by knowıng about the process can we have access to the essence of his architecture 8

9) For Eisenman, architecture is manifested in its gestation 9

10) And because of the virtual erosion of the exterior faces, elements of the structure appear here and there, becoming autonomous Iconographic features with a value of their own Eisenman's interest in asserting the autonomy of the architectural form, its lack of obligations to function and use, is manifested in an architecturally canonical element, namely the staircase Proof of this autonomy is the staircase's formal ambivalence Eisenman manifests this through the paint colors, which confer on the upper end of the staircase a value identical to that of the lover, while presenting it from being confined between two vertical planes House VI emphatically assets the importance of the nucleus, hence the loss of interest in the periphery which has less energy and vibrancy than we saw in the facades of house II In other words, the cube loses its value as such when the nucleus becomes the basıs for defining it ${ }^{10}$

11) Thereafter Eisenman would try to Justify his projects through texts that explicated the new themes of interest, suggestıng that architecture had the capacity to reflect in them In addition to linguists lıke Chomsky or pure visualists like Slutzky, Eisenman began to resort to thınkers lıke Foucault, Lacan, Deleuze, Derrıda The "architectural Ideas" he had pursues in his early works - Ideas which, as we saw, were often confused with the inithation of the process - gave way to ideological proposals with real capacity to give content to his work His projects ceased to be objective, abstract Ideas, sımple geometric stimulı over a neutral and universal scheme that got a process of formal development going They were now interpretations of historic evolution that could be materialized in a form, if one grants that there is room for metaphor in architecture Architecture was once again spurred by reality, history ${ }^{11}$

12) Decomposition goes further in that it proposes a radically altered process of making from either modernısm or classicısm Decomposition presumes that origıns, ends, and the process itself are elusive and complex rather than stable, simple or pure, that is, classical or natural However, decomposition is not merely the manifestation of the arbitrary, the intuitive, or the irrational or the makıng of somethıng sımple from somethıng complex By proposing a process which at root is the negative or inverse of classıcal composition, the process uncovers (or deconstructs) relationshıps inherent in a specific object and its structure which were previously hidden by a classıcal sensıbility Rather than workıng from an orıgınal type toward a predıctable end, decomposition stats with a heurıstic approxımation of end, an end which is immanent withın the new object process 12

13) The result is another kınd of object, one which contains a nonexistent future as opposed to an irretrievable past The removal of the identity and significance from objects signals a uselessness The futtle object and the process of decomposition are no longer arbitrary objects and anomalous processes, nor a mutation of classicism In this new time they may have become, albeit accidentally, the destny of architecture today ${ }^{13}$

14) "In house II, the built object becomes a diagram of the process The object and the diagram are both one and the other, the real house operatıng sımultaneously as a diagram"14

15) Eisenman understands the computer's incredible potential in the transformation and manipulation of form But this potentnal needs a starting point, a graphic abbreviation, a diagram For Eisenman, the diagram is to computer-generated architecture what the part was to the architecture governed by academic compositional criteria With the computer as a tool, Eisenman decided it was possible to present the beginnings of his career through the notion he so enthusiastically puts forward in his latest publication ${ }^{15}$

\section{0 - DECONSTRUCTION MOTIFS}

\section{IHE DIAgrams of ARCHIIEcture Editor Mark Garcia}

1) For Derrida, writing is inithally a condition of repressed memory The repression of writing is also the progression of that which threatens presence, and since architecture is the sine qua non of the metaphysıcs of presence, anything that threatens presence would be presumed to be repressed in architecture's interiority In this sense architecture's anteriority and interiority can be seen as a sum of repressions While all discourses representation, architecture must be seen as a special case because of its privileging of presence If Derrida is correct, there is already given in the interiority of architecture a form of representation, perhaps as the becoming unmotivated of the architectural sign This repressed form of representation is not only interior to architecture, but anterior to it it is this representation in architecture that could also be called a writing How this writng enters into the diagram becomes a critical issue for 
architecture ${ }^{1}$ (Garcia 98)

2) A plan is a finite condition of writing, but the traces of writing suggest many different plans it is the idea of the trace that is important for any concept of the diagram, because unlike a plan, traces are neither fully structural presences nor motivated signs Rather, traces suggest potential relationships, which may both generate and emerge from previously repressed or unarticulated figures But traces in themselves are not generative, transformative or even critical A diagrammatic mechanism is needed that will allow for both preservation and erasure and that can sımultaneously open up repression to the possibılity of generating alternative architectural figures which contain these traces ${ }^{2}$

3) Derrida savs 'we need a sıngle apparatus that contains a double system, a perpetually avaslable innocence and on infinite reserve of traces' 3

\section{2 - DECONSTRUCTION. A STUDENT GUIDE - AuthOR GEOffrey BROADbent}

4) In the architectural debate, no element may function as a sign without referring to another element which is not present The result of this combination is that each element turns itself into a sign which combines other elements of the system Each web is a text produced only by transformıng one text from the others Nothıng, neither amongst the elements nor withın the system, is not found to be either present or absent 4

5) Thus, it is a question of breakıng down the author's powers in order to impose meaning and to offer a continual narration, continuity, in the final instance is reduced to signs (signs of signs) that leave fragments which pass from production to consumption 5

6) There are no fixed systems of representation in the synthesıs - only routes or paths of explanation A readıng (of a poem, picture, or buildıng) assumes a permanent organızation - disorganızation - re-organization - deconstruction Any reading is, therefore, both possible and necessary ${ }^{6}$

7) For Eisenman, what propels this new method is an expansion further away from the limits of the classical model towards the realızation of architecture as an independent power, free from external duties, this is the intersection of what is significant, arbitrary, timeless and artificial 7

8) The deconstructivist architect should stop being a decorator of life and become an organizer of life, creating new concept of architectural space Moreover, through deconstruction, the architect has his programme, his tool, his means and a message 8

9) (EIsenman's) His aım at that time had been an architecture of pure 'syntax' with no 'semantic' references of the kınd which we call, loosely, 'meanıng' So Eisenman had used geometric rules derived from those which, accordıng to Noam Chomsky (1956), we humans apply subconsciously whenever we formulate and speak or write a sentence 9

10) Chomsky had argues (1956) that these rules are of two kınds generative - by whıch we formulate our basıc sentences, and transformational - by which we convert them into active, passive, negative, questioning or other forms Of course there is much more to it that that, but there are two crucial points here one, that Eisenman was tryıng to create an architecture of pure geometric syntax with no semantic 'meanıng' at all, and two, that he drew on Chomsky to give his work a certaın 'Intellectual' stffenıng (See Evans 1985 ) 10

11) Wigley believed that, far from deriving from the writings of Jacques Derrida, such work was, in its way, homage to Russian Constructivism ${ }^{11}$

12) But Wigley sees his Deconstructivism as no mere Constructuvist Revival The Constructivists, he felt, 'interrogated Modern Movement forms' and since his Deconstructivists follow simılar procedures it is hardly surprising that they 'discover' forms much like those of the Constructivists Or, as Wigley puts it 'in dismantlıng the ongoing tradition they find themselves inevitably rehearsing the strategies rehearsed by the (Russian) avant-garde They 'irritate modernısm from withın, distorting it with its own genealogy' 12

13) So Wigley seeks a form of 'Deconstructivism' in which archıtecture will be free from the influence of any language or philosophy But his 'Deconstructivism' opens the flood gates, for if 'Constructivism' was an influence-as clearly it was, if only in the works of Meier and Tschumı - then many other Modern '-Ists' and 'Isms' can be seen as equally legıtımate sources ${ }^{13}$ 
14) In each case Derrida aıms to refute the author with arguments derived from the latter's own writings, to demonstrate - successfully in many cases - that the very premises on which the author bases his case will, if pursued to their logical conclusions, defeat the original arguments Such writing contains withın itself the seeds of its own destruction ${ }^{14}$

15) "Somethıng has been constructed, a philosophical system, a tradition, a culture, and along comes a de-constructor (who) destroys it stone by stone, analyses the structure and dissolves it One looks at a system and examınes how it was bult, which keystone, which angle supports the building, one shifts them and thereby frees oneseif from the authority of the system " 15

16) Syntactic Desıgn in which one draws on a set of geometric rules, like the rules of syntax in language, and derives one's forms accordingly Eısenman's early houses are perfect examples 16

10 HOUSE $V I$

1 Frank Suzanne Peter Eisenmans House VI The Client s Response New York Whitney Library of Design 1994 p 23

2 ibıd

3 ibid $p 24$

4 Davidson Cynthı ed Tracıng Eısenman New York Rızzolı 2006 p 57

5 ibid $p 59$

$\begin{array}{lll}6 & \text { ibid } p & 66 \\ 7 & \text { ibid } \mathrm{p} & 104\end{array}$

8 Moneo Rafael Theoretical Anxiety and Design Strategies Cambridge MIT Press 2004 p 151

9 ibid $p$ 152

10 ibid p 163

11 ibid p 169

12 ibid p 173

13 ibid p 174

14 ibid p 194

20 DECONSTBUCTION MOTIFS

1 Eisenman Peter Diagrams An Origınal Scene of Writing Op cit The Diagrams of Architecture p 98

2 ibid

3 ibid

4 Broadbent Geoffrey Deconstruction A Student Guide Ed Jorge Glusberg London Academy Group 2006 p 7

5 ibid

6 ibid $p 8$

7 ibid $p$

8 ibid

9 ibid $p 13$

10 ibid

11 bid p 23

12 ibid $p 24$

13 ibld p 25

14 ibid $p 31$

16 ibid p 81 


\section{APPENDIX F: \\ ARCHITECTURAL DIAGRAMS}

\section{0 - DIAGRAMS}

\section{Practice Architecture technique + Representaiton Author Stan Allen}

1) James Clerk Maxwell emphasizes the relational and transactional character of the diagram, which he defines as "a figure drawn in such a manner that the geometrical relations between the parts of the figure illustrate relations between other objects" All notations are diagrammatic but not all diagrams are notational 1

2) A diagram is often thought of as an after-the-fact thıng, an explanatory device to communicate or clarify form, structure, or program But this overlooks the diagram's generative capacity The diagram is architecture's most condensed and powerful tool for thınkıng about organızation ${ }^{2}$

3) In an ımmediately accessıble and highly telegraphıc form, diagrams specify part to whole relationshıps and suggest a workıng model of the whole Readıng a diagram is more or less instantaneous, there is an Immedıate apprehension of the relations between the parts,

4) The configurations it develops are momentary clusters of matter in space, subject to continual modification A diagram is a descripthon of potential relationshıps among elements, not only an abstract model of the way things behave in the world, but a map of possıble worlds ${ }^{4}$

5) Unlıke classical theories based on ımitation, diagrams do not map or represent already existing objects or systems but anticıpate new organizations and specify yet to be realized relationships The diagram is not simply a reduction from an existing order Content is not embedded or embodied, but outlıned and multiplıed Sımplified and highly graphic, diagrams support multiple interpretations Diagrams are not schemas, types, formal paradigms, or other regulatory devices, but sımply placeholders - instructions for action, or contingent descriptions of possible formal configurations ${ }^{5}$

6) A diagram is a graphic assemblage that specifies relationshıps between activity and form, organızing the structure and distrıbution of functions 6

7) Instead, a diagram architecture is an architecture that behaves like a diagram, indifferent to the specific means of its realization 7

\section{2 - IHeoretical anxietr and Design strategies author rafael moneo}

8) "Elsenman understands the computer's incredible potential in the transformation and manipulation of form But this potental needs a starting point, a graphic abbreviation, a diagram" 8

9) Eısenman has introduced an ımportant idea from generative, or transformational grammer, in which language is seen as a generative activity rather than as a description of semantic and syntactric relationshıps in this view of language, syntactic takes on a new meanıng where syntactic structure itself is seen as the primary generator of language Eisenman incorporates this concept into archıtecture because it helps hım account for what he sees as a sımılar process of synthesis in architecture, the process of the generation of architectural form 9

10) “The diagram is not only an explanation, as somethıng that comes after, but it also acts as an intermediary in the process of generation of real space and time" 10

11) "as a generator there is not necessarily a one-to-one correspondence between the diagram and the resultant form "11

12) "The diagram as a form of writing, because it introduces a non-presence as an absence in presence, allows the possibility of overcomıng the idea of a motivated sign 12

13) The diagram, hence, as a hidden generative matrıx givıng rıse to internal shıftıng ${ }^{13}$ 
14) "In this context, the diagram begins to separate form from function, form from meaning, and architects from the process of design The diagram works to blur the relationshıp between the desırıng subject - the desıgner, the user - and the desired object in order to move both subject and object towards an unmotivated condition But at the same time, as Massımo Cacciarı points out, it is problematic to act as a negative agent in architecture" 14

\section{3 - IHE Diagrams of ARCHIIECTURE Editor Mark garcia}

15) A diagram is the spatialization of a selective abstracting and/or reduction of a concept or phenomenon In other words, a diagram is the architecture of an idea or entity 15

16) The diagram, like the writing pad, contains the sımultaneity of the appearance on its surface, what would be akın to the black lines on the top layer of the pad, as well as the indentations in the wax below the second aspect of the time of the diagram is succession, which is akın to the liftıng up of the pad and its Involved in erasure and the posting of a new Image This is the permanence in the wax Itself $\mathbf{1 6}$

17) Thus, the diagram is an intermediate or interstitial condition which lies between in space and tme - between the architectural object and the interiority of architecture ${ }^{17}$

18) diagram enables an author to overcome and access the history of the discourse while sımultaneously overcomıng his or her own psychical resıstance to such an act ${ }^{18}$

19) Eisenman's reformulation of the diagram in response to the questions is in order to 'write' and rewrite the metaphysics of presence in architecture, as well as to construe the diagram as 'a means of reversing the motivated design process' His analysis centres on how architects (as designers) 'externally' motivate architectural sins through their desires when they apply an 'artificial set of signifiers' that move an architectural sıgn beyond its architecturally 'structurıng or internal motivation' He describes how the diagram can become the 'negative or resistant agent' in, and 'overcome', the motivated sign in architecture, in place and in the subject's desıre for architecture and place to have stable, communıcating sıgnifiers The diagram does this by producing arbitrary connections to the signified, separating the relationships between form, function and meanıng Diagrams are presented as being able to work to separate or distance the object or place and the subject, moving both towards an unmotivated condition $\quad 19$

20) The diagram would be a means of reversing the motivated design process by insisting on its presence as a primary condition 20

21) In order to rethınk presence, the diagram attempts to overcome the subject's initial desire for a communıcating signifier The diagram does this by producing a set of arbitrary connections to the signified by separating the motivated relationships between form and function, and form and meaning This removal and rupture allows a possible not-presence, a void withın presence to be This not-presence is a writing ${ }^{21}$

22) This introduces the strategy of the diagram as a negative or resistant agent in this context, the diagram begins to separate form from function, form from meanıng, and architect from the process of design The diagram works to blur the relationship between the desiring subject - the designer, the user - and the desired object in order to move both subject and object towards an unmotivated condition But at the same time, as Massimo Cacciarı point out, it is problematic to act as a negative agent in architecture 22

23) What is a diagram? In general, diagrams are best known and understood as visual tools used for the compression of information ${ }^{23}$

24) In architecture, diagrams have in the last few years been introduced as part of a technıque that promotes a proliferatnng, generating and Instrumentalizıng approach to design 24

25) An Image is a diagram when it is stronger than its interpretations 25

26) The diagram is not a metaphor or paradıgm, but an 'abstract machıne' that is both content and expression This distinguishes diagrams from indexes, icons and symbols The meanings of diagrams are not fixed The diagrammatic or abstract machine is not representational It does not represent an existing object or situation, but it is instrumental in the production of new ones 26 
27) Why use diagrams? Diagrams practice delays the relentless intrusion of sıgns, thereby allowing architecture to articulate an alternative to a representational desıgn technıque $A$ representational technıque implies that we converge on realıty from a conceptual position and in that way fix the relationshıp between idea and form, between content and structure When form and content are superımposed in this way, a type emerges This is the problem with an architecture that is based on a representational concept it cannot escape exısting typologıes in not proceedıng from sıgns, an instrumentalızıng technıque such as the dıagram delays typologıcal fixation Concepts external to architecture are introduced rather than superimposed Instances of specific interpretation, utilization, perception, construction and so on unfold and brıng forth applications on various levels of abstraction 27

28) The computers allow us to construct organizations and images that we have never seen before, and therefore could have never Imagined - without its existence 28

29) If the realization of the possible is a matter of interpretation, or redescription of a given set of identities or organizations, the actualization of the virtual can never operate by resemblance, and therefore it requires tools that will allow us to see - and therefore to Imagıne, to conceptualise - what we have never seen before It is precisely this capacity to expand our perception to domains beyond our experiential knowledge, and to control and accurately determıne the processes of construction, that makes the computer an ideal instrument for the production of the virtual 29

30) The diagram does not belong to a logıc of representation, lıke the other sıgns, but Inaugurates a logıc of sensation aımed at bringıng forward new worlds The diagram allows the emergence of another possible world ${ }^{30}$

31) In a diagrammatic process, the project keeps a capacity to trigger possıbilities The project retains its virtualities, which become only partially actualized, keepıng the possibility to develop ad infinitum In a diagrammatic practice the moment of closure is determıned by factors external to the project, and the propositional moments, the aıms and strategies, are not restricted to the origın or the end, but to the interstices of the process Between the form of the diagram and the final form of the building, additional information needs to be added ${ }^{31}$

32) James corner has argues that representation is both analytical and generative, and diagrams express thıs dual function 32

33) Diagrams are also generative tools - agents of investigation and revelation, forming the armatures on which ideas can condense Through expressıng or reformulating ideas, diagrams can open things out in a way that allows for a transcendıng or subverting of the status quo, as a means of generation in design As well as their pragmatic strengths in communication, diagrams also have poetic potentral through their abılity to create new association, to excavate affinities, to become vehicles for discovery ${ }^{33}$

34) The diagrams are, in effect, an abbreviated expression of design process ${ }^{34}$

35) Design diagrams not only sımplıfy and abstract the complexity of the world, both actual and Imagined They also express and arthculate the complex nature of design itself 35

36) Diagram, latit, diagramma, these mean varıously that which is marked, figured, traced, symbolized, written or drawn out It comes from the greek dia- meanıng 'across, out or between-two' and gramma meanıng 'figure, mark or line that is made' ${ }^{36}$

37) Even in architecture and other spatal desıgn discipiınes, there is little consensus on any more precise way to define and dıstınguısh, in all cases, the diagram from larger related thıngs such as the drawing, sketch, Illustration, visualızation, model, map, process and metaphor 37

38) The problem with such a broad definition is that it dilutes the meaning of the term to the extent where it begins to decompose and collapse into even more general and unhelpfully vague concepts such as form, system, schema, space, structure, simulation, process, pattern, suggestion, analogy, influence and inspiration 38

39) Diagrams (like process-based and conceptual works of art and architecture) can be highly obscure, esoteric and personal, and made, used and experiences in such uncertaın mental states, contexts and conditions that they can be consıdered, in Umberto Eco's sense, polyguous, 'open works' of sorts ${ }^{39}$

40) of their ability to refer to mystic-religuous ideas 40 
41) The diagram has infiltrated the separate discourses of architecture's other modes and media )the diagramatisation/diagramatics of the drawing, model, anımation, installation, text, etc) with the hybridizing insertions into them of diagrammatic methods methodologies, practices and techniques, as well as forms, structures and processes ${ }^{41}$

42) The diagram is an essentially modern mode of representation its genius lies in the invention of a discursive code that organizes reality in order that it may be both visible and usable ${ }^{42}$

43) Nelson " the diagrammatic process must sustain a universal logıc, a rational and creative process that produces new and unıque results" 43

44) Nelson, diagrams were 'schematic and flow process drawıngs' emanating form 'governıng ideas and prıncıples - the ideology' Representing 'ideal space arrangements' and 'ideal schemes of interrelationshıp' these diagrams were then 'crystallized' in the third and final stage, into an 'unforseen architecture unforeseen because it is the program of life with its imponderables which inspired these architectural forms, these harmonies, these multiple complexites, no architect could have anticipated' 44

45) that plans, Sections and elevations, those traditional modes of architectural representation, are themselves diagrams 45

46) The architects of the neo-avant garde are drawn to the diagram because - it appears in the first instance to operate precisely between form and word that it is fundamentally a disciplinary device in that it situates itself on and undoes specific institutional and discursive oppositions, that it suggests an alternative mode of repetition, and that it is a performative rather than a representational device (ie It is a tool of the virtual rather than the real) 46

47) And it enact this possibility not by representing a particular condition, but by subverting dominant oppositions and hierarchies currently constitutive of the discourse ${ }^{47}$

48) Diagrammatic work is projective in that it opens new (or, more accurately, 'virtual') territories for practice, ${ }^{48}$

49) Deleuze "It is like the emergence of another world the diagram is the possibility of fact - it is not the fact itself" 49

50)This 'emergence of another world' is precisely what the diagram diagrams this diagrammatic alternative can be seen inıtially in Elsenman's process automısm ${ }^{50}$

51) For eisenman, the diagram traces and writes, and can be traced and read in, architecture As such, the diagram mediates between the history of architecture (diagrams of anteriority) and the ways in which this is traced in a real building and the other possible buildings that are withın it (dragrams of interıority) Diagrams of exterıority, those from outsıde architecture, are defined as agents from the 'specific site, the programme, or the history' ${ }^{1}$

52) Diagram is historically understood in two ways as an explanatory or analytical device and as a generative device 52

53) As a generative devise in a process of design, the diagram is also a form of representation But unlike traditional forms of representation, the diagram as a generator is a mediation between a palpable object, a real building, and what can be called architecture's interiority 53

54) These lines are the trace of an intermediary condition (that is, the diagram) that exists between what can be called the anteriority and the interiority of architecture, the summation of its history as well as the projects that could exist are indexed in the traces and the actual building ${ }^{54}$

55) The diagram is not only an explanation, as something that comes after, but it also acts as an intermediary in the process of generation of real space and time As a generator there is not necessarily a one-to-one correspondence between the diagram and the resultant form 55

56) If in the interiority of architecture there is a potentrally autonomous condition that is not already socialized or that is not already historicized, one which can be distilled from a historicized and socialized interiority, then all diagrams do not necessarily take up new 
discıplınary and social Issues Rather, diagrams can be used to open up such an autonomy to understand its nature This exıstng condıtion can be called architecture's interiority ${ }^{56}$

57) The architectural diagram, like the mystic writing pad, can be conceived of as a series of surfaces or layers which are both constantly regenerated and at the same time capable of retainıng multiple series of traces Thıs, what would be seen in an architectural object is both the first perceptual stimulus, the object itself, along with its aesthetic and iconicf qualities, and another layer, the trace, a written index that would supplement this perception Such a trace would be understood to exist before perception, in other words, before a perception is conscious of itself 57

\section{0 - ANTERIOR/INTERIOR/EXTERIOR TRACES}

\section{IHe Diagrams of Architecture Editor Mark garcia}

1) These lines are the trace of an intermediary condition (that is, the diagram) that exists between what can be called the anteriority and the interiority of architecture, the summation of its history as well as the projects that could exist are indexed in the traces and the actual buildıng ${ }^{1}$

2) The diagram is not only an explanation, as somethıng that comes after, but it also acts as an intermediary in the process of generation of real space and time As a generator there is not necessarily a one-to-one correspondence between the diagram and the resultant form ${ }^{2}$

3) If in the interiority of architecture there is a potentrally autonomous condition that is not already socialized or that is not already historicized, one which can be distilled from a historicized and socialized interıority, then all diagrams do not necessarıly take up new disciplınary and social Issues Rather, diagrams can be used to open up such an autonomy to understand its nature This exısting condıtion can be called architecture's interiority ${ }^{3}$

4) For Derrida, writing is initially a condition of repressed memory The repression of writing is also the repression of that which threatens presence, and since architecture is the sine qua non of the metaphysics of presence, anything that threatens presence would be presumed to be repressed in architecture's interiority in this sense architecture's anteriority and interiority can be seen as a sum of repressions While all discourses represnetation, architecture must be seen as a special case because of its privileging of presence If Derrida is correct, there is already given in the interiority of architecture a form of representation, perhaps as the becomıng unmotivated of the architectural sign This repressed form of representation is not only interior to architecture, but anterior to it it is this representation in architecture that could also be called a writing How this writing enters into the diagram becomes a critical issue for architecture ${ }^{4}$

5) A plan is a finite condition of writng, but the traces of writing suggest many different plans It is the idea of the trace that is important for any concept of the diagram, because unlike a plan, traces are neither fully structural presences nor motivated signs Rather, traces suggest potential relationships, whıch may both generate and emerge from previously repressed or unarticulated figures But traces in themselves are not generative, transformative or even critical A diagrammatic mechanısm is needed that will allow for both preservation and erasure and that can simultaneously open up repression to the possibility of generating alternative architectural figures which contain these traces 5

6) Derrida says 'we need a sıngle apparatus that contaıns a double system, a perpetually avallable innocence and on infinıte reserve of traces' 6

7) The diagram acts like a surface that receives inscriptions from the memory of that which does not yet exist - that is, of the potential architectural object 7 )

8) Each diagram is therefore a schema - a representational analogue - of the designer's own conception of the world, a microcosm of their disciplıne 8

9) diagrams 'carry' Ideas into another form, and the process of abstraction can involve a leap of faith in terms of comprehension 9

10) the physical column is simultaneously an object and the sign of the object Initially because the column is a sign of itself, it can be considered as an indexical sign in that it receives its motivation from an internal, prior condition - the interiority of its being 10 


\section{Iheoretical anxiety and Design Strategies author rafael moneo}

11) The fantacy of autonomous architecture was replaced by an architecture contaminated by the outsıde world - a world to take into account, like it or not Architecture should reflect the instability of history and there was no way out of this ${ }^{11}$

12) In the interiority of architecture there is also an a priorı history, the accumulated knowledge of all previous architectures" 12

13) "Albert suggests that Vitruvius did not mean that buildings should be structural, but that they should look like they are structural with Albert, architecture for the first time concerns not only its being - the fracture itself - but also its representation both inside and outsıde of Its being" 13

14) pg 196 In other words, architects want to make the interıority of architecture present, visıble For eisenman, "normalization" - submission to the norms inherent in history - is a risk that is implicit in the notion of anteriority And to oppose it he coins the term "presentness" To define it 14

15) "Presentness is that condition which allows the object to remain unabsorbed into the normalized interiority of architecture it allows the object to remain outside of its original time as a critical instrument" 15

\section{3 - Practice ARChitecture Technique + Representation author Stan Allen}

16) Even in the most ideal careers, many decisions are beyond the control of the individual architect The process of design and construction is characterized by constant tactical adjustments made to the demands of clients, codes, consultants, budgets, builders, and regulatory agencies, not to mention the complex logistics of construction itself The practice of architecture tends to be messy and inconsistent precisely because it has to negotnate a reality that is itself messy and inconsistent 16

17) Against this landscape of contingency, architectural theory has tradittonally served a unifyıng function Without a larger ideological framework, it is argues, the architect runs the risk of reacting passively to the multiple and often contradictory demands of context, clients, regulating agencies, media, or economics Architecture, it is argued, needs a grand narrative in order not to be entirely consumed by these small narratives of opportunity and constraint And so, in order to legitmate its mechanical procedures, practice appeals to a project an over-arching theoretical construct, defined from someplace other than the studıo or the building site, and expressed in a medium other than buildings and drawings Detached from the operational sites of technique, theory stakes a claım on a world of concepts uncontamınated by real world contingencies Theory needs distance for its reflections, but as a consequence of that detachment, the possibility of incremental change from withın is held in check Theory's promise is to make up for what practice lacks, to confer unity on the wildly disparate procedures of design and construction 17

\section{4 - TRACING EISENMAN EDITOR CYNTHIA DAVIDSON}

18) Thus the object not only is the end result of its own generative history but also retains this history, serving as a complete record of It, process and product begınnıng to become interchangeable 18

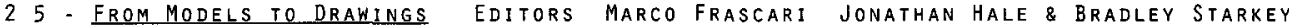

19) In this sense, such architectural works re-present the pictorial and mode-based 'representations' that facilitated their generation, or, in visionary and Imaginative terms, pre-projected the possibilities of their reality 19

20) Models and drawings become past approxımations of present architectural bult-forms, if they have informed the generation of such architectural works They must also be grasped as being suggestive modalities of visualızıng what is 'not-yet' materially accomplished or what, in deferrals, might never be realızed Such 'representations' are determıned agaınst the horizon of temporality, in the sense that they are at times anterior to what they 'represent' (or pre-represent), hence, they are 'proto-presentations' in being prior to the realization of what they point at 20

26 IHE SPACE OF ENCOUNIER - AUTHOR DANIEL LIBESKIND

21) An architecture drawing is as much a prospective unfolding of future possibilities as it is a recovery of a particular history to whose Intentions it testifies and whose limits it always challenges ${ }^{21}$ 


\section{0 - MODEL DIAgRaMS}

$$
31 \text { - ARCHItectural MOdel as Machine Author a C SMith }
$$

1) If one accepts that an architectural scale model can serve as a representation of ınvisıble thıngs, then the scale model can be regarded as a form of icon An icon is an Image, lıkeness or representation of something it is a picture of a sign that is lıke an image of the thing it indicates or represents 1

2) as a mechanısm for thınkıng, medıatıng between the confusıon of nature and human desıgns 2

3) The word 'model' is borrowed from Middle French modele, from Italıan modello, or model or mold, from the vulgar Latin modellus Modellus is a dimınutive of the latin modulus, a dımınutive of modus, which means to measure A model is typıcally a small object, usually built to scale, that represents another, often larger object It can be a prelımınary pattern, servıng as a plan, from whıch an item not yet constructed will be produced A model can also offer a tentative description of a theory or system that accounts for all its known properties ${ }^{3}$

4) For, when humans develop a measure, they are offered a standard, an acceptable unit of quantitative or qualitative value by which somethıng intangıble is determıned or regulated In this sense, measurıng is important in the search for understandıng However, If the measurement is not fully defined, the development of the measurement process becomes itself, an essential part of the process of understandıng The scale model offers humans an understandable surface (framework) upon which they can project and develop their measures of invisible things 4

5) It is through the attempt to measure thıngs that are invisıble that humanity creates the analogies - the reference standards - which serve as a framework withın whıch to develop the interpretive narrations of our scale model machıne In other words, the measurer's relationshıp with the invisıble is ımportant for definıng the measurement through the scale model machıne 5

6) For example, the Catholıc relıgıon Itself is measured through the cathedral The buıldıng demonstrates the story of medieval Catholıcısm to an illiterate population through sculpture and staıned glass windows Each door and window defined the relıgıon in a sımple direct way to the reader The buildıng becomes a device for thınkıng about the measurements of the organızation of the church and, thus, is an example of a scale model machıne 6

7) The scale model machıne has thus an exoteric or scientific aspect, and an esoteric or mystical aspect 7

8) It is human nature to look for order within the vacuum of chaos As the age-long investigation of order plunges humanity into a dark vold, the darkness is finally defined by the gropıng psyche of the measurer who projects thoughts on to the mechanism of the scale model Thus, through the indirect methods of projection and free association, the measurer comes to activate the unconscious which allies itself to his or her work in the form of hallucinatory or visıonary experiences 8

9) Each measurement of an unknown involves a comparison with a carefully conserved known Humans define a measurement of an unknown by comparıng it directly with a known device, which has been previously developed to agree with reference measurement standards 9

10) According to Duchamp, 'The artist is a mediumistic being who does not really know what he is doing or why he is doing it it is the spectator who through a kınd of ınner osmosis, decipherıng and interpreting the works' inner qualıfications, related them to the external world, and thus completes the creative process 10

11) Hans continues, "Thıs [play] requires that the "rules" of the game that the work of art itself establishes - the player begins with his own fore-conceptions, but he must be led by the work itself, must accept the rules of the work itself 'Through the back-and-forth movement withın the circle of the play, the rules become established [defined], the participant modifies his own projections accordIngly, and he comes to understand the work of art precisely through the series of reversals of his own expectations which the correcting of his fore-projections involves 11 


\section{0 - The 'Abstract Machine' \\ 4.1 - Practice. Architecture Technique + Representation Author: Stan allen}

1) "An abstract machıne in itself is not physical or corporeal, any more than it is semiotic, it is diagrammatic. It operates by matter, not by substance; by function, not by form. The diagrammatic or abstract machıne does not function to represent, even somethıng real, but rather constructs a real that is yet to come, a new type of reality. ${ }^{1}$

\subsection{IHE DIAGRAMS OF ARCHITECTURE - EDITOR: MARK GARCIA}

2) Deleuze, Abstract machınes are precisely what they claım to be. they are abstract because conceptually and ontologically distinct from material reality yet they are fully functionıng machınes nonetheless, that 15 , they are agencies of assemblage, organızation and deployment . ${ }^{2}$

3) Definition: 'it is the function of these traces that is important. .[the diagram] Illustrates a definition, aids in the proof of a proposition, it represents the course of results of any action or process' Vidler's definitions are derived from Peirce's and Deleuze's notion of the diagram as an 'icon of relationships' which specifies, in a particular way, 'the relations between unformed/unorganized matter and unformalısed/unfinıshed functions.' Vidler seems to accept Deleuze's notion of the diagram as a spatial-temporal abstract map/ machıne and 'multiplicity' whıch 'refuses every formal distinction between a content and an expression' Further, he distinguishes the way in whıch diagrams differ from drawings, namely that diagrams represent abstractions 'symbolically'. ${ }^{3}$

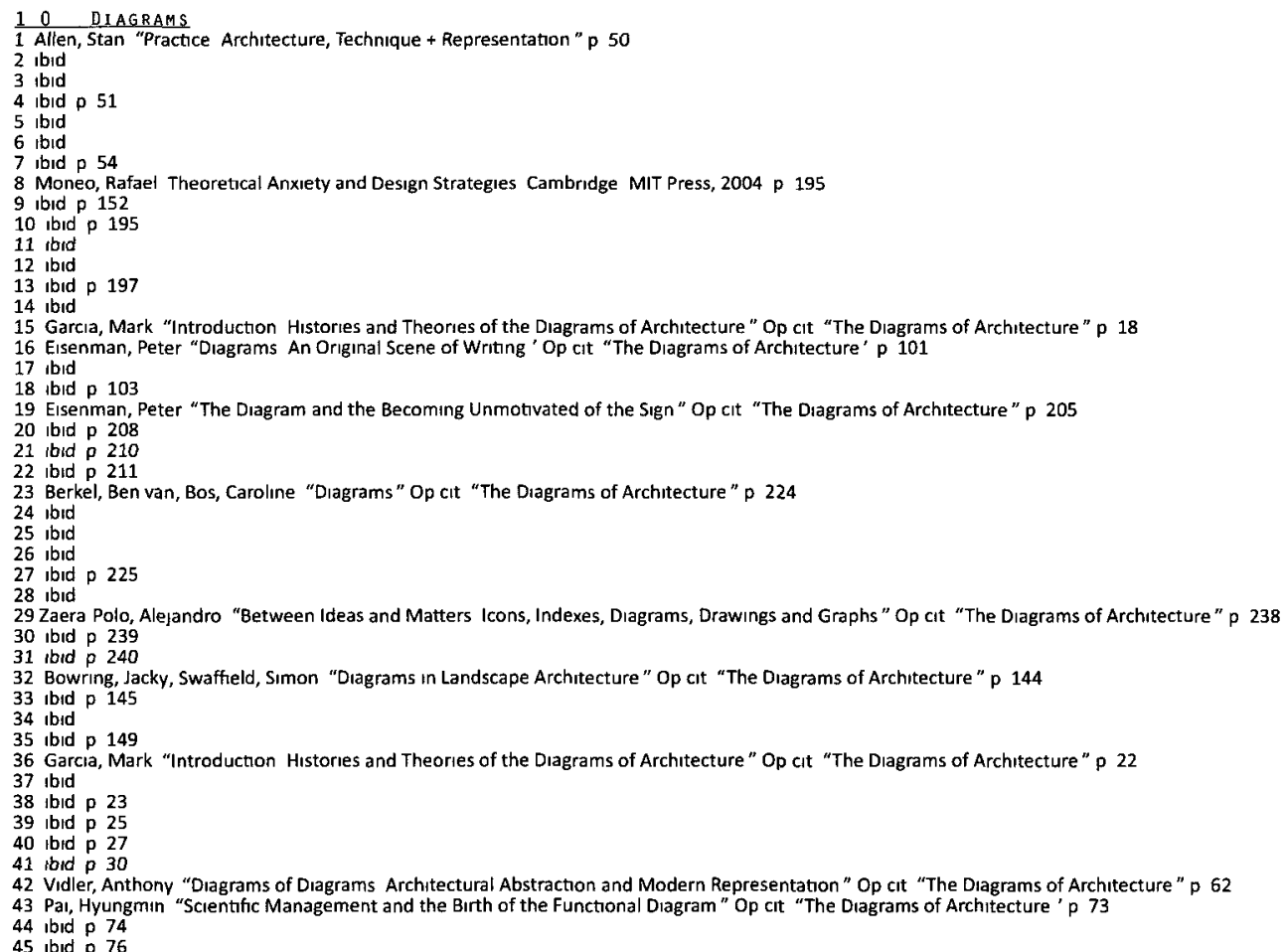




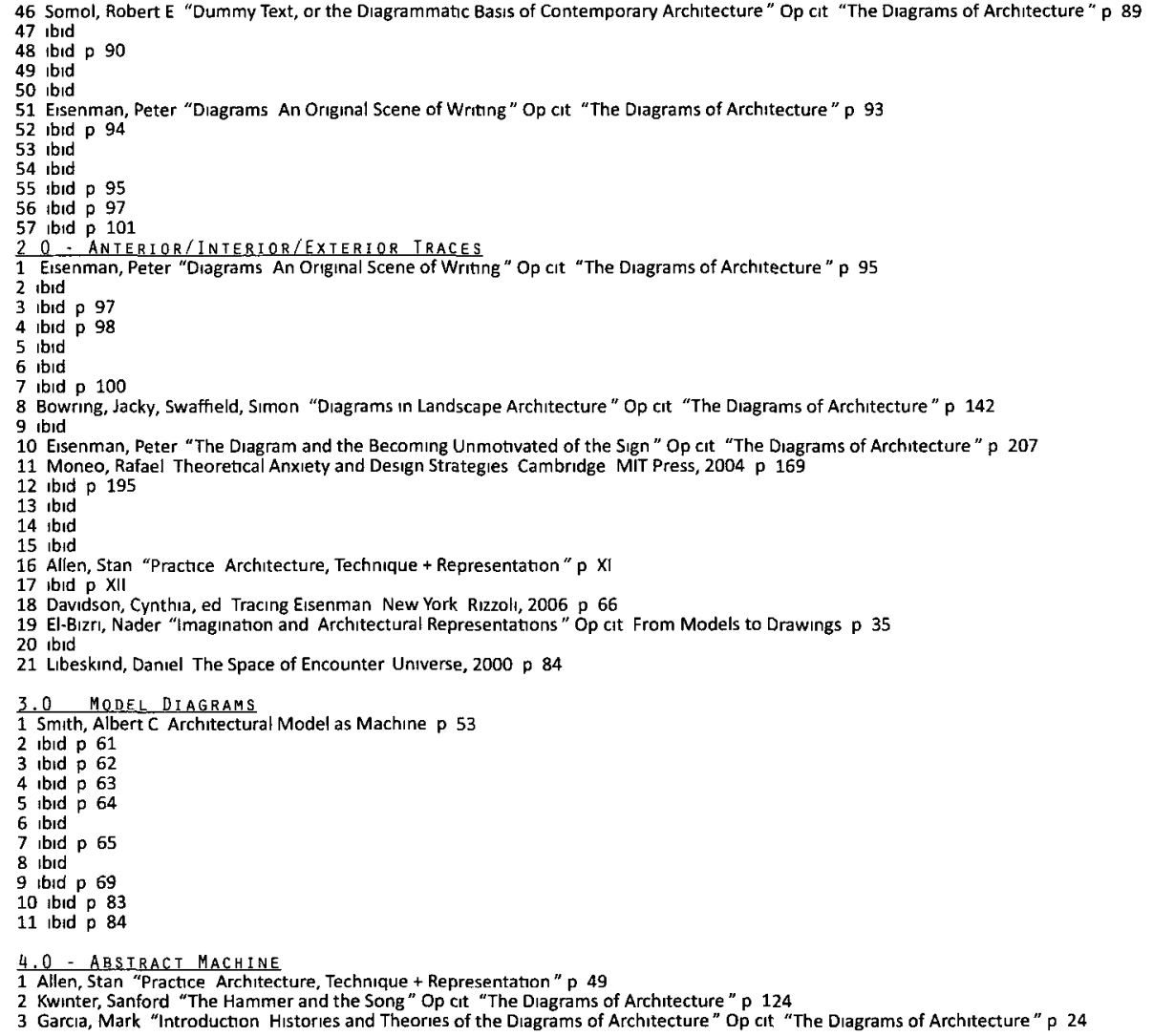




\title{
APPENDIX $G$ :
}

\section{CABINET OF CURIOSITIES (WUNDERKAMMERN)}

\author{
1.0 - MR. WILSON'S CABINET OF WONDER - AUTHOR: LAWRENCE WESCHLER
}

1) By the late sixteenth and early seventeenth centuries, this sort of hoard (the chamber of wonders, in which the word wonder refereed both to the objects displayed and the subjective state those objects inevitably induced in their respective viewers) was rampant all over Europe, and the question arises Why Or rather, why then? And of course the answer, as Platter's awestruck inventory of Cope's treasure trove itself suggests, lies in the avalanche of marvelous new stuff that had suddenly begun pourıng over the transom into a previously parochial, hidebound, closed-European subcontinent In particular, the stuff of the New World ${ }^{1}$

2) Stephen Greenblatt's masterfully evocative study Marvelous Possessions The Wonder of the New World (1991) "Wonder," Greenblatt argues, was "the central figure in the initial European response to the New World, the decisive emotional and Intellectual experıence in the presence of radical difference" By the late sixteenth and early seventeenth centuries, this sort of hoard (the chamber of wonders, in which the word wonder refereed both to the objects displayed and the subjective state those objects inevitably induced in their respective viewers) was rampant all over Europe, and the question arises Why Or rather, why then? And of course the answer, as Platter's awestruck inventory of Cope's treasure trove itself suggests, lies in the avalanche of marvelous new stuff that had suddenly begun pouring over the transom into a previously parochıal, hıdebound, closed-European subcontinent in particular, the stuff of the New World 2

3) Stephen Greenblatt's masterfully evocative study Marvelous Possessions The Wonder of the New World (1991) "Wonder," Greenblatt argues, was "the central figure in the initial European response to the New World, the decisive emotional and Intellectual experience in the presence of radıcal difference" 3

4) As the historian Michel de Certeau has written, "An absence of meanıng opens a rift in time" And that experience of the ground openıng before one's feet was at the heart of the sensation of wonder ideally afforded by (or at any rate striven toward in) many of the cabınets of the time ${ }^{4}$

5) As Greenblatt goes on to observe, "The expression of wonder stands for all that cannot be understood, that can scarcely be belıeved It calls attention to the problem of credıbility and at the same time insists upon the undeniability, the exigency of experience $" 5$

6) The point is that for a good century and a half after the discovery of the Americas, Europe's mind was blown That was the anımatIng spirit behınd, and the endurıng significance of, the profusion of Wunderkammern It wasn't just the American artifact that they displayed It was how the palpable reality of such artifacts so vastly expanded the territory of the now readily conceivable Horns, for example, were suddenly all the rage rhınoceros horns, unicorn horns, sea unicorn horns, human horns rhınoceros horns were real, and sea unicorns did exist so why couldn't unicorn horns or human horns exist as well? 5

7) Often there seemed to be no order whatsoever to the pell-mell pile, or non discernıble to us, save that of contnuous, compounding amazement The seventeenth century museum "was still conceived of as a place where one could move about without having to solve or face the problem of contnuity" 7

8) Wunderkammer-men "were not alone among men of science [of their time] in lookıng upon wonder and marvel as upon one of the essential components of the study of nature and the unraveling of its secrets wonder defined [as it was up to the end of the eıghteenth century] as a form of learnıng - an intermedıate, highly particular state akın to a sort of suspensıon of the mınd between Ignorance and enlightenment that marks the end of unknowıng and the begınnıng of knowing" 8

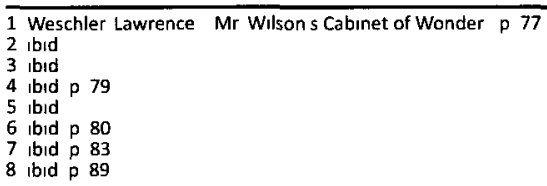




\section{B I B L I OGRAPHY}

AHRA. From Models to Drawings: Imagination and Representation in Architecture. Ed. Marco Frascari, Jonathan Hale and Bradley Starkey. New York: Routledge, 2007.

Alberti, Leon Battista. On the Art of Building in Ten Books. Trans. Joseph Rykwert, Neil Leach and Robert Travernor. MIT Press, 1997 [1452].

Allen, Stan. Practice: Architecture, Technique + Representation. New York: Routledge, 2009.

Auerbach, Anthony W. Structural Constellations: Excurses on the drawings of Josef Albers c. 1950-1960. PhD Thesis. London: University College London, 2003.

Bedard, Jean-Francois, ed. Cities of Artificial Excavation: The Works of Peter Eisenman, 1978-1988. Montreal: Canadian Centre for Architecture, 1994.

Birnholz, Alan C. "El Lissitzky and the Spectator: From Passivity to Participation." The Avante-Garde in Russia, 1910-1930. Los Angeles: Los Angeles County Museum of Art, 1980. 98-101.

Bliznakov, Milka. "The Rationalist Movement in Soviet Archtiecture in the 1920's." 20th Century Studies, Russian Formalism. Brighton: Dolphin Press, 1993. 150-151.

Bowlt, John E. "Manipulating Metaphors: El Lissitzky and the Crafted Hand." Situating El Lissitzky: Vitebsk,

Bredekamp, Horst. The Lure of Antiquity and the Cult of the Machine: The Kunstkammer and the Evolution of Nature, Art and Technology. Trans. Allison Brown. New York: Marcus Weiner, 1995.

Broadbent, Geoffrey. Deconstruction: A Student Guide. Ed. Jorge Glusberg. London: Academy Group, 2006.

Bucher, François. Joseph Alber: Despite Straight Lines: An Analysis of His Graphic Constructions. Cambridge: MIT Press, 1977.

Cooper, Douglas. Drawing and Perceiving: Life Drawing for Students of Architecture and Design. Wiley, 2000.

Davidson, Cynthia, ed. Tracing Eisenman. New York: Rizzoli, 2006.

Deleuze, Gilles and Felix Guattari. A Thousand Plateaus: Capitalism and Schizophrenia. Trans. Brian Massumi. Minneapolis: University of Minnesota Press, 2003.

Diaz, Eva. The Ethics of Perception: Josef Albers in the United States. Vol. XC. The Art Bulletin, 2008.2 vols.

Dijk, Hans van. "Interview Peter Eisenman." zonder functie green architectuur maar van belang is het overwinnen van de functie no. $21 / 22$ (1980): 30 .

Eisenman, Peter. Eisenman Inside Out: Selected Writings 1963-1988. New Haven: Yale University Press, 2004.

Evans, Robin. "Architectural Projection." Architecture and Its Image, Four Centuries of Architectural Representation: Works From the Collection of the Canadian Center of Architecture. Cambridge, Massachusetts: MIT Press, 1989.

-. The Projective Cast: Architecture and Its Three Geometries. Cambridge: MIT Press, 2000.

-. Translations from Drawing to Building. Cambridge: MIT Press, 1997.

Fiorani, Francesaco. Renaissance Quarterly 51.1 (1998): 268-270.

Forty, Adrain. Words and Buildings: A Vocabulary of Modern Architecture. Thames \& Hudson, 2000. 
Frank, Suzanne. Peter Eisenman's House VI: The Client's Response. New York: Whitney Library of Design, 1994.

Galofaro, Luca. Digital Eisenman: An Office of the Electronic Era. Trans. Lucinda Byatt. Basel: Birkhauser, 1999.

Garcia, Mark. The Diagrams of Architecture. Chichester: John Wiley \& Sons Ltd, 2010.

Greenblatt, Stephen. Marvelous Possessions: The Wonder of the New World. Chicago: University of Chicago Press, 1991.

Harbeson, John. The Study of Architectural Design. New York: Pencil Points Press, 1926.

Henderson, Linda Dalrymple. The Fourth Dimension and Non-Euclidean Geometry in Modern Art. Vol. XVII. Leonardo, 1984. III vols.

Libeskind, Daniel. Countersign. Academy Editions, 1991.

-. The Space of Encounter. Universe, 2000.

Lodder, Christina. Russian Constructivism. London and New Haven: Yale University Press, 1983.

Margolin, Victor. The Struggle for Utopia: Rodechenko, Lissitzky, Moholy-Nagy, 1917-1946. Chicago: University of Chicago Press, 1997.

Minai, Asghar Talaye. Design as Aesthetic Communication: Structuring Random-Order; Deconstruction of Formal Rationality. New York: Peter Lang, 1989.

MoMA. The Collection. 2010. 21 November $2010<$ http://www.moma.org/collection/object.php?object_ id $=79040>$.

Moneo, Rafael. Theoretical Anxiety and Design Strategies. Cambridge: MIT Press, 2004.

Oxford. Oxford Dictionaries. 21112010 <http://oxforddictionaries.com/?attempted=true>.

Re:Working Eisenman. London: Academy Editions, 1993.

Scolari, Massimo. Elements for a History of Axonometry. Venice: The School of Venice, 1985.

Smith, Albert C. Architectural Model as Machine. Oxford: Architectural Press, 2004.

Smith, Kendra Schank. Architects' Drawings: A selection of sketches by world famous architects through history. Oxford: Architectural Press, 2005.

Uddin, M. Saleh. Axonometric and Oblique Drawing: A 3-D Construction, Rendering, and Design Guide. New York: McGraw-Hill, 1997.

Vitruvius. The Ten Books on Archtiecture. Trans. Morris Hickey Morgan. New Yorm: Dover Publications Inc., 1960.

Weschler, Lawrence. Mr. Wilson's Cabinet of Wonder. New York: Vintage Books, 1996.

Winkler, Ramona. Optical Illusions. Ed. Gerd Waloszek. April 2006. November $2011<\mathrm{http}: / / w w w . s a p-$ designguild.org/resources/optical_illusions/optical_illusions.pdf>.

Witold Gilewicz, Lidia Gilewicz. "Perspective Drawing in the Architectural Design Process." Journal for Geometry and Graphics 1 (1997): 59-60.

Wright, Lawrence. Perspective in Perspective. London: Routledge, 1983. 
JARED J. HAGENS

$04 / 12 / 2011$ 